\title{
European mutual funds
}

Citation for published version (APA):

Otten, R. R. A. E. (2002). European mutual funds. [Doctoral Thesis, Maastricht University]. Universiteit Maastricht. https://doi.org/10.26481/dis.20020627ro

Document status and date:

Published: 01/01/2002

DOI:

10.26481/dis.20020627ro

Document Version:

Publisher's PDF, also known as Version of record

\section{Please check the document version of this publication:}

- A submitted manuscript is the version of the article upon submission and before peer-review. There can be important differences between the submitted version and the official published version of record.

People interested in the research are advised to contact the author for the final version of the publication, or visit the DOI to the publisher's website.

- The final author version and the galley proof are versions of the publication after peer review.

- The final published version features the final layout of the paper including the volume, issue and page numbers.

Link to publication

\footnotetext{
General rights rights.

- You may freely distribute the URL identifying the publication in the public portal. please follow below link for the End User Agreement:

www.umlib.nl/taverne-license

Take down policy

If you believe that this document breaches copyright please contact us at:

repository@maastrichtuniversity.nl

providing details and we will investigate your claim.
}

Copyright and moral rights for the publications made accessible in the public portal are retained by the authors and/or other copyright owners and it is a condition of accessing publications that users recognise and abide by the legal requirements associated with these

- Users may download and print one copy of any publication from the public portal for the purpose of private study or research.

- You may not further distribute the material or use it for any profit-making activity or commercial gain

If the publication is distributed under the terms of Article $25 \mathrm{fa}$ of the Dutch Copyright Act, indicated by the "Taverne" license above, 


\section{European Mutual Funds}


ISBN 9090159185 


\title{
European Mutual Funds
}

\author{
PROEFSCHRIFT
}

ter verkrijging van de graad van doctor aan

de Universiteit Maastricht,

op gezag van de Rector Magnificus, Prof. dr. A.C. Nieuwenhuijzen Kruseman, volgens het besluit van het College van Decanen, in het openbaar te verdedigen op donderdag 27 juni 2002 om 16.00 uur

door

Rogér Rene Anna Elisabeth Otten 


\section{Promotor:}

Prof. dr. C.G. Koedijk

\section{Beoordelingscommissie:}

Prof. dr. F.C. Palm

Prof. dr. P.M.A Eichholtz

Prof. dr. J.M.G Frijns
(Voorzitter)

(Vrije Universiteit Amsterdam) 


\section{Preface}

The journey has come to an end. After four volatile years I hereby present to you my Ph.D. dissertation. This dissertation would not have been there without the help and moral support of several people. First of all I owe a lot to Mark Schweitzer. As my enthusiastic master thesis supervisor Mark introduced me to Kees Koedijk back in 1997. After a ten-minute meeting Kees talked me into a Ph.D. which, I only found out later, would change the entire course of my life. Especially during the first $1 \frac{1}{2}$ years Mark and I worked together on several projects. He pulled me through the difficult start-up period every Ph.D. student experiences, for which I am very grateful. Many thanks also go to Kees Koedijk, my Ph.D. supervisor. Although Kees moved to Rotterdam already in my second year, he has been a constant factor in the whole process. Even from a distance Kees was always there for me. Especially at the most crucial moments he expressed his confidence in me. This was invaluable. Very special thanks also go to Dennis Bams. Although we became roommates involuntary, Dennis turned out to be a major contributor to my dissertation. He showed me the beauty of financial econometrics, which led to three joint papers. Although I benefited from his academic toolbox, Dennis also became a good friend who always had an opinion on everything, and everyone.

Although writing a Ph.D. dissertation can be a rather lonely venture, the people at the Finance Department of Maastricht University always provided the necessary distraction. During our many (lost) soccer games, hiking trips, dinners at the "Preuverij" and high quality lunches in the Mensa, we were able to forget about writing papers and talked about the more important matters in life. Special thanks go to all my former roommates at University, including Arjan, Dennis, Mathijs, Kim and Aline. Their (amateur) psychology kept me going.

Besides working at University I also had the opportunity to gain valuable practical experience at ABP Investments in Heerlen and Amsterdam. For this I am especially grateful to Rob Bauer and Jelle Mensonides. Furthermore I thank all my former colleagues at the equity department for showing interest in my work. 
Next to these professional colleagues I also have been lucky to keep in contact with my dd friends from the "real" world. During the many car trips to disco's and pubs in the beautiul province of Limburg, I found out that there is more to life than examining error terns, although these trips led to a lot of errors as well.

Veruit mijn grootste dank gaat echter naar mijn ouders. Alhoewel jullie niet altijd preces wisten waar ik mee bezig was, voelden jullie feilloos aan wanneer ik jullie steun het hardte nodig had. Zonder jullie relativerende blik op het leven had ik het zeker niet gered. Ik ben trots op zulke ouders.

\section{Rogér Otten}

Maastricht, April 2002 


\section{Contents}

1 Introduction 1

$\begin{array}{lll}1.1 & \text { Outline } & 2\end{array}$

2 Literature Survey on Mutual Funds 5

2.1 A Primer on Mutual Funds 5

2.1.1 The Concept 5

$\begin{array}{ll}2.1 .2 \text { Regulation } & 6\end{array}$

$\begin{array}{lll}2.1 .3 \text { Costs } & 7\end{array}$

2.2 The Structure of the Mutual Fund Industry 8

2.3 Performance Measurement 9

2.3.1 General Results 9

$\begin{array}{ll}2.3 .2 & \text { Survivorship Bias } \\ & 11\end{array}$

$\begin{array}{lll}2.3 .3 & \text { Persistence } & 11\end{array}$

2.4 Style Analysis 13

2.5 Contribution of this Thesis 14

$\begin{array}{lll}2.5 .1 & \text { Structure } & 14\end{array}$

$\begin{array}{lll}2.5 .2 & \text { Performance } & 14\end{array}$

$\begin{array}{lll}2.5 .3 & \text { Style Analysis } & 15\end{array}$

3 Comparing the European and the US Mutual Fund Industry 17

$\begin{array}{lll}3.1 & \text { Introduction } & 17\end{array}$

3.2 The Structure of the Mutual Fund industry in Europe and the United States 18

3.3 Conduct in the Industry 24

3.4 Performance of the Mutual Fund Industry 26

$\begin{array}{lll}3.4 .1 \text { Data } & 27\end{array}$

$\begin{array}{ll}3.4 .2 & \text { Summary Statistics } \\ 3.4 .3 & 28\end{array}$

$\begin{array}{ll}\text { 3.4.3 Development through Time } & 29\end{array}$ 
3.4.4 Are Funds doing what they are supposed to do? 32

3.4.5 The Influence of Fees on Performance 35

3.4.6 The Under-performance of European Index Funds 36

3.4.7 The Out-performance of Small Cap Mutual funds 36

3.5 Conclusions 37

4 Mutual Fund Performance Models 39

$\begin{array}{lll}4.1 & \text { Introduction } & 39\end{array}$

$\begin{array}{lll}4.2 & \text { Mutual Fund Performance Models } & 40\end{array}$

$\begin{array}{ll}4.2 .1 & \text { Unconditional Models } \\ 40\end{array}$

4.2.2 Conditional Models $\quad 42$

4.3 Data 43

4.3.1 The CRSP Survivorship-bias Free US Mutual Fund Database $\quad 43$

4.3.2 Mutual Fund Data 44

4.3.3 Benchmark Indices and Predetermined Information Variables $\quad 44$

4.4 Empirical Results $\quad 46$

4.4.1 All funds Portfolio $\quad 46$

$\begin{array}{llr}4.4 .2 & \text { Survivors } & 49\end{array}$

$\begin{array}{lll}4.4 .3 & \text { Investment Style Level } & 51\end{array}$

4.5 Discussion of the Results and Conclusion 56

5 European Mutual Fund Performance $\quad 59$

$\begin{array}{llr}5.1 & \text { Introduction } & 59\end{array}$

5.2 The European Mutual Fund Industry 61

$\begin{array}{lll}5.3 & \text { Data } & 63\end{array}$

5.3.1 European Mutual Funds $\quad 63$

$\begin{array}{lll}5.3 .2 & \text { Benchmarks } & 64\end{array}$

5.4 Performance Measurement 66

5.4.1 Mutual Fund Performance Models 66

$\begin{array}{lll}5.4 .2 & \text { Results } & 69\end{array}$

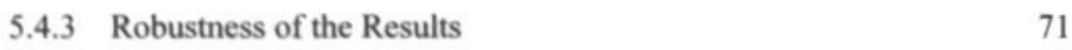

$\begin{array}{ll}5.4 .4 & \text { Management Fees } \\ \end{array}$

5.5 Persistence 76

5.6 The Influence of Fund Characteristics on Risk-Adjusted Performance $\quad 81$

5.7 Summary and Conclusions 83

6 Ethical Mutual Funds $\quad 85$

$\begin{array}{lll}6.1 & \text { Introduction } & 85\end{array}$ 
$\begin{array}{lll}6.2 & \text { Data } & 87\end{array}$

$\begin{array}{lll}\text { 6.2.1 General Market Overview } & 87\end{array}$

$\begin{array}{ll}\text { 6.2.2 Ethical Mutual Funds } & 88\end{array}$

$\begin{array}{ll}\text { 6.2.3 Benchmarks } & 90\end{array}$

6.3 Empirical Results $\quad 90$

$\begin{array}{lll}\text { 6.3.1 CAPM Model } & 90\end{array}$

$\begin{array}{lll}\text { 6.3.2 Multi-Factor Model } & 94\end{array}$

6.3.3 Conditional Multi-Factor Model 96

6.4 Development of Relative Performance through Time 98

$\begin{array}{ll}\text { 6.5 Conclusion } & 104\end{array}$

7 Return-Based Style Analysis 107

$\begin{array}{lll}7.1 & \text { Introduction } & 107\end{array}$

7.2 Stylized facts of Sharpe's Model for Return-Based Style Analysis $\quad 109$

7.3 Econometric Method 110

$\begin{array}{lll}7.4 \text { Data } & 113\end{array}$

$\begin{array}{lll}7.5 & \text { Results } & 114\end{array}$

$\begin{array}{lll}7.6 & \text { Robustness Tests } & 120\end{array}$

$\begin{array}{lll}7.7 & \text { Summary and Conclusions } & 121\end{array}$

$\begin{array}{ll}\text { Appendix 7A } & 122\end{array}$

8 Summary and Concluding Remarks 127

$\begin{array}{ll}\text { References } & 131\end{array}$

Nederlandse samenvatting / Dutch summary 137

$\begin{array}{ll}\text { Curriculum Vitae } & 141\end{array}$ 



\section{Chapter 1}

\section{Introduction}

During the last decade European mutual fund assets rose from $€ 0.7$ trillion in 1990 to $€ 4$ trillion in 2000. Moreover, $15 \%$ of European citizens participate in one or more mutual funds. The popularity of this investment vehicle can be traced back to its clear advantages. By pooling money into investment funds, the investor gains access to easy diversification at much lower costs, because of economies of scale. In addition to that, it is expected that fulltime mutual fund managers are able to run the fund in a more profitable way than the investor could do himself.

Before an investor decides to participate in a mutual fund there are several relevant questions he would like to have answers on. For instance, how the industry is organized, through which channels to buy a fund, and how high the associated costs are. Obviously, another crucial factor would be the performance of a mutual fund compared to the general market and/or compared to competing mutual funds. Finally an investor might be concerned with the fact whether the mutual fund manager does actually stick to the investment style that was agreed upon.

This thesis investigates these issues along three lines. Namely, the structure, performance and style analysis of European mutual funds. By providing a thorough analysis of the mutual fund industry we try to add to the understanding of European financial markets. These results should be of interest to both private and institutional investors, regulators and of course academics.

Until now, academic research on European mutual fund issues is limited to only a few studies on individual countries. The United States however has a much longer mutual fund history. Their 7 trillion USD industry has gained the attention of numerous academic studies. The result of 30 years of academic research on US mutual fund performance for instance indicates that US mutual funds are quite able to follow general market indices like the S\&P 
500 before costs are deducted. If however the costs of owning a fund are subtracted, the average mutual fund trails the index by about the amount of expenses that were charged to the investor.

This thesis tries to fill this lack of European mutual fund studies through the construction of a comprehensive European mutual fund database and the development of more advanced performance measurement models. Especially in the light of the European unification we focus on Europe as a whole and try to answer some timely questions concerning the functioning of the European mutual fund industry. After providing a thorough overview of the structure of the European industry versus the US industry we focus on the performance measurement of European fund managers. By using the most recent model specifications we address the question whether European fund managers are able to beat the market, or like their US peers, are trailing the index after expenses have been deducted.

In addition to that we investigate an issue that received a lot of media attention lately, the determination of a mutual funds' investment style. Recently, this point clearly came forward in a $€ 200$ million lawsuit the Anglo-Dutch Unilever pension fund filed against its external manager, US Merrill Lynch Investment Management (MLIM) in 1999. By deviating from an agreed investment style, MLIM allegedly under-performed the market by over $10 \%$, while it was only allowed to under-perform by $3 \%$ a year. After a two-year battle in court, MLIM recently agreed to pay about $€ 110$ million in compensation to Unilever's pension fund. However without admission of liability. This case calls for better performance measurement and style determination techniques.

The next section gives a detailed outline of all individual chapters.

\subsection{Outline}

Chapter 2 presents a primer on mutual fund investing, after which an overview of the literature on mutual fund studies is given. The discussion covers the three main topics this thesis will address: 1. Structure 2. Performance 3. Style analysis. For all three themes we cover the European and US evidence separately. In addition, in section 2.5 it is stated what contribution this thesis makes in all three areas.

Chapter 3 provides an analysis of the structure of the European mutual fund industry. More specifically it analyses the development and performance of the European mutual fund industry and compares it with the industry in the United States. Although chapter 3 provides a first analysis of European fund performance, the main focus lies on issues like industry concentration, growth potential, distribution channels and fee structures. The measurement of mutual fund performance will be dealt with in more detail in chapters 4 through 6 . The results of chapter 3 indicate that Europe is still lagging the American mutual fund industry when it 
comes to total asset size, average fund size, and market importance. Furthermore, it appears that a few large domestic fund groups dominate the mutual fund markets in the individual European countries. The performance of domestic equity funds is tested using a data set containing the main European countries and the United States. The most striking results of these performance tests are the relative poor performance of US funds, compared to the European funds, and the out-performance of small cap mutual funds.

Chapter 4 is entirely dedicated to the search for the most relevant mutual fund performance model. Using a recently released database on all US mutual funds it provides a comprehensive assessment of existing mutual fund performance models. Starting with the most basic single factor CAPM model, we then explore the added value of introducing extra variables like size, book-to-market, momentum and a bond index. In addition to that we evaluate the use of introducing time-variation in style (beta) and performance (alpha) parameters. Our main goal is to determine which model is best suitable to measure mutual fund performance. This is done by assessing both the statistical and economic relevance of a range of model specifications. The reason for the use of a US database lies in the richness of the database, over 40 years of returns on about 12.000 funds. The results of this chapter however will be used throughout the remainder of this thesis. Where possible we explore whether the results on US mutual fund performance models can be confirmed by using European data. Chapter 4 reveals three major findings. First, multi-factor models are clearly superior to single factor models when measuring performance. Second, conditioning betas on publicly available information provides a significant improvement in explanatory power. Third, we find only very little evidence of significant time-variation in fund alphas

Chapter 5 builds upon the results in chapter 4 . Using more elaborate multi-factor models we evaluate European mutual fund performance. By employing a survivorship bias controlled sample of 506 funds from the 5 most important European mutual fund countries we document the following findings. Overall European mutual funds, and especially small cap funds are able to add value, as indicated by their positive after cost alphas. If we add back management fees, 4 out of 5 countries exhibit significant out-performance at an aggregate level. Finally, we detect strong persistence in mean returns for funds investing in the United Kingdom. Our results deviate from most US studies that argue mutual funds under-perform the market by the amount of expenses they charge.

Chapter 6 deals with one of the latest trends in asset management: SRI or also called ethical investing. Issues like the environment, civil rights and nuclear energy served to increase the social awareness of investors. Accordingly mutual funds were set up which met the demand for incorporating ethical criteria in the investment process. This led to a dramatic increase in ethically managed mutual fund assets. At the moment almost $13 \%$ of money under professional management in the United States is part of a socially responsible portfolio. Using an international sample of 103 US, UK and German ethical funds we address the central question whether ethical funds differ in terms of risk-adjusted return and investment style 
from conventional funds. Principal objective will be to investigate whether the return on ethical investments transcends market cycles and style preferences. By applying the multifactor models used in chapters 4 and 5, we solve the benchmark problem most prior ethical studies suffered from. After controlling for investment style, we find little evidence of significant differences in risk-adjusted returns between ethical and conventional funds for the 1990-2001 period. Introducing time-variation in betas however leads to a significant underperformance of domestic US funds and a significant out-performance of UK ethical funds, relative to their conventional peers. Finally, we differentiate previous results by documenting a learning effect. After a period of strong under-performance, older ethical funds finally are catching up, while younger funds continue to under-perform both the index and conventional peers.

Chapter 7 concentrates on estimating investment styles of mutual funds. As it is commonly known that mutual funds have the incentive to game their stated investment style. This chapter explores the merits of a popular approach to estimate mutual fund styles, returnbased style analysis (RBSA). RBSA investigates the exposure of mutual funds to a number of style indices. Because the style weights need to meet particular constraints, traditionally only point estimates of the style exposures have been reported. In this chapter we include the entire asymptotic distribution of the style weights. These results are obtained by applying a combination of the Kuhn-Tucker optimization algorithm and standard bootstrapping. This allows us to infer confidence intervals for the style coefficients, and to carry out statistical tests on the parameters. Empirical tests on a sample of UK equity funds, demonstrate the usefulness of this extra information, in the light of the mutual fund misclassification phenomenon.

Chapter 8 finally provides a conclusion and summary of the main findings of this thesis. 


\section{Chapter 2}

\section{Literature Survey on Mutual Funds}

\subsection{A Primer on Mutual Funds}

\subsubsection{The Concept}

Mutual funds are investment companies organized to allow investors to participate in a portfolio of assets. Traditionally these companies can be grouped into two broad categories: open-end and closed-end investment companies. While closed-end investment companies are often called closed-end mutual funds, the term "mutual fund", is most commonly applied to the open-end company.

Closed-end investment companies are structured like a standard corporation.' They issue a fixed number of shares and invest the proceeds in a portfolio of assets. These shares are traded on a regular secondary market at prices that are determined by supply and demand. There are typically no further shares offered by the investment company, and it does not repurchase the shares on demand. The closed-end investment company's net asset value (NAV) is computed twice a day based upon prevailing market prices for the securities in the portfolio. The market value of shares in the fund is determined by the relative supply and demand for the investment company stock in the market. As the fund is traded at market value, and not at NAV, stocks in the fund may exhibit a discount (market value $<\mathrm{NAV}$ ) or a premium (market value $>\mathrm{NAV}$ ). In the long run, the market price of closed-end funds has historically been from 5 to $20 \%$ below NAV. As this thesis exclusively deals with open-end mutual funds we will not explore this in more detail. ${ }^{2}$

\footnotetext{
'In the UK closed-end funds are referred to as "investment trusts".

${ }^{2}$ For a overview of the literature on closed-end fund discounts, see Dimson and Minio-Kozerski (1999).
} 
In contrast to closed-end funds, open-end or mutual funds are funds for which shares continue to be bought and sold after the initial public offering is made. ${ }^{3}$ They stand ready to sell additional shares at the NAV of the fund. In addition, mutual funds stand ready to buy back shares of the fund at the NAV at any time. As mutual fund shares are always bought and sold at NAV, no discounts or premiums are possible.

After this short introduction on the mutual fund concept we now turn to the regulatory framework that influences the mutual fund industry. Several new developments in this area are likely to change the European mutual fund landscape in the near future.

\subsubsection{Regulation}

In the US two fundamental regulatory acts affected the securities industry: the 1933 "Securities Act" and the 1934 "Securities Exchange Act". The 1933 act required registration of publicly traded securities and specified that "material information" must be made available to investors in a prospectus. Furthermore it prohibited deceit, misrepresentation and other fraud in the sale of securities. The 1934 act created the Securities and Exchange Commission (SEC) to enforce federal laws, required securities exchanges and broker-dealers to register with the SEC and forced companies to distribute periodic reports to shareholders. Finally the recently enacted National Securities Markets Improvement Act of 1996 substantially changed the regulatory structure for mutual funds. Most importantly it eliminates the prohibition of investments by mutual funds in shares of other mutual funds, thereby allowing mutual funds to offer shares in so-called "funds of funds". In addition, it allows shares in unregistered private pools, such as hedge funds and venture capital funds, to be offered to an unlimited number of "qualified" investors. ${ }^{4}$

The existence of this strict regulation has triggered a huge amount of academic research on issues regarding the US mutual fund industry. As all investment companies are obligated to report on a wide variety of issues to the SEC, data is abundantly available. Companies like Morningstar, Lipper and Wiesenberger now market commercial databases containing returns, asset allocation, fees, size etc on over 10.00 mutual funds with a 40 year history. Academics can acquire a wide variety of databases at low costs, an ideal situation for exploring the US mutual fund industry.

In Europe the situation is completely different. As virtually every country has its own securities market regulation, no comprehensive law on mutual fund companies exists. Especially this fact led to the lack of studies on the European mutual fund industry, because of the unavailability of historic databases. Recently this situation is changing. Companies like Morningstar and Standard \& Poor diversify their efforts towards Europe, and are setting up

\footnotetext{
${ }^{3}$ In the UK open-end or mutual funds are mainly referred to as "unit-trusts".

"A qualified investor is an individual with more than 5 million USD in assets or an institution with over 25 million USD in assets.
} 
local offices to collect and market European mutual fund data. Furthermore the council of the European Community introduced the UCITS I (Undertakings for Collective Investments in Transferable Securities) directive in 1996, which aims at enhancing the distribution of funds through the entire European Community (EC). This directive builds upon the innovative concept of "mutual recognition". A provider can now offer a mutual fund under the UCITS regulation, approved in its home country, across all EC countries with no need to go through the authorization process in each of the countries. Finally in December 2001 the European Parliament approved the newest UCITS directive. Among the changes in the new directive is the inclusion of new fund structures such as funds of funds, money market, cash and index tracker funds under UCITS, as well as enabling a broader use of derivates. In addition, the introduction of harmonized and more simplified prospectuses have been approved. EU governments now have 18 months to implement the directive into national legislation. These directives are expected to give a strong boost to the European fund market, by creating a single fund structure and thus achieving economies of scale.

\subsubsection{Costs}

The final point of interest in this primer on mutual funds is the costs a mutual fund investor faces. Owning a mutual fund mostly leads to several kinds of costs. First, the fees and commissions paid to the agents responsible for mutual fund services, the advisor, distributor or custodian. Besides the bid-ask spread paid to a market maker, these costs could include a front-end load and/or back-end load. The first one is paid when entering the fund, while the second has to be paid when leaving the fund. Second, the annual management fee which enables the fund manager to run the fund. Third, a percentage to cover the cost of marketing the fund. This marketing cost, in the US also called $12 \mathrm{~b}-1$ charge, is mainly related to the sales channel. In the US, the National Association of Securities Dealers (NASD) has established an upper limit for $12 \mathrm{~b}-1$ charges of $0.75 \%$ of the fund's NAV, and an upper limit of $6.25 \%$ to total fund loads. Furthermore the SEC requires all funds to disclose a total expense ratio (TER) prominently and in plain language. As a result of this, a US investor is always aware of the costs involved in mutual fund ownership.

In Europe no such body supervises and/or regulates mutual fund costs. As a result of that, the costs of mutual fund ownership vary considerably throughout the EC. In addition, there is evidence that costs reported by mutual fund companies heavily under-estimate the actual costs. Recent research by Fitzrovia International, a London-based fund research firm, revealed that the reported costs for UK funds largely under-estimate the true costs because administration costs, legal and audit fees have not been included. ${ }^{5}$ The company thinks that

\footnotetext{
${ }^{5}$ See Economist (1999) for details.
} 
the best guess would be to double the reported fees to get the true TER. In chapter 3 we explore this issue in more detail.

\subsection{The Structure of the Mutual Fund Industry}

An important feature of any financial market is its inherent structure. Issues like competition, scale and fee setting are known to influence the performance of an industry heavily. Several studies explored the structure and conduct in the US mutual funds industry. For instance Collins and Mack (1997) investigate economies of scale. They conclude that medium sized fund companies can achieve substantial economies of scale by increasing assets under management. In addition, a broadening of the product line leads to further economies of scale.

Two recent studies by Khorana and Servaes $(1999,2001)$ partly confirm and extend this US evidence. Khorana and Servaes (1999) find that larger fund families are more likely to open new funds, in line with the presence of economies of scale. Furthermore they find that smaller fund families mimic the behavior of the larger firms, large firms thus innovate, while the smaller ones replicate. Khorana and Servaes (2001) examine the competition in the US mutual fund industry and present two interesting conclusions. First, mutual fund families that perform better, offer a wider range of products and start more funds, have a higher market share. Second, too high levels of innovation lead to the cannibalization of existing funds. Finally a study by Tufano and Sevick (1997) studied the influence of board structure on fee setting in the US. Mutual funds with larger boards charge higher management fees. In addition, if a fund pays its board relatively high salaries, this board is in turn more likely to approve higher management fees to be paid by investors.

Dermine and Roller (1992) examine economies of scale and scope in French mutual funds. Their main finding relates to the diseconomies of scale for larger fund families, while the smaller funds potentially have more economies of scale and scope. Finally Walter (1999) covers the global asset management industry. Among others, he expects a fierce competition between European fund companies as financial markets become fully integrated. Banks could lose their dominance and management fees will come under pressure as competition heats up. This to the benefit of both the individual and institutional investor.

\subsection{Performance Measurement}

\subsubsection{General Results}

This section provides a brief overview of the academic work on mutual fund performance. Using the most important studies, this section summarizes the results of 40 years of mutual fund research. As the intention is to provide a summary on the qualitative results and 
implications of the most influential studies, this section will not discuss the underlying econometric models. Chapter 4 is entirely devoted to the model specification process, when evaluating fund performance.

Besides offering advantages related to cost-efficiency and facilitating easy diversification, the main argument for investing in a mutual fund is the ability of a fund manager to obtain "superior" returns. To investigate whether a manager is really able to deliver superior returns, his or her performance is often compared to a broad market proxy. For instance, the return on a US equity mutual fund is compared to the return on the S\&P 500 index. Although this "relative" form of performance measurement is often cited in the popular press, it does not take into account the cornerstone of modern finance, the risk-return relationship.

Therefore, already back in the 60's, academics used the Capital Asset Pricing Model (CAPM) to assess mutual fund performance using risk-adjusted returns. For instance Jensen (1968) studied 115 US funds during the 1945-1964 period. He found the average fund to under-perform the S\&P 500 by $1.1 \%$ per year, after expenses have been deducted. As a result of this study it was widely believed that the empirical evidence on mutual fund performance was in line with the Efficient Market Hypothesis (EMH). Indicating that expenditures of money on research and trading are wasted, because security prices already reflect all available information. Michael Jensen was even quoted saying:

"It's difficult to systematically beat the market. But it's not difficult to systematically throw money down a rat hole by generating commissions". 6

About two decades later this idea faced severe opposition when a study emerged that provided evidence of significant after cost out-performance of US funds. Ippolito (1989) evaluated 143 mutual funds over the 1965-1984 period. By using the S\&P 500 in a CAPM framework he found a significant out-performance of $0.81 \%$ per year for the average fund.

The Ippolito study marked the renewed interest in mutual fund performance measurement. Several authors attributed his result to benchmark inefficiencies. By using the S\&P 500, a large cap index, one does not take into account holdings in for instance smaller company stocks. As small cap stocks out-performed large stocks during the 1965-1984 period, the Ippolito results could be driven by the small cap exposure of the funds in his sample. For this reason Elton, Gruber, Das \& Hlavka (1993) propose to add a small cap benchmark to the previous 1-factor CAPM model. While this small cap index turns out to be a significant factor, it also makes the average fund under-perform the market by $1.49 \%$ per year during the 1965-1984 period. In addition to that, Fama \& French $(1992,1993,1996)$ provide strong evidence for the relevance of yet another factor, besides a small cap index. Based on

\footnotetext{
${ }^{6}$ M. Jensen, quoted in Forbes, October 8, 1984.
} 
their work on the cross-sectional variation of stock returns, Fama \& French (1993) propose a 3-factor model. Besides a value-weighted market proxy two additional risk factors are used, size and book-to-market. Gruber (1996) uses a similar 3-factor model to evaluate the riskadjusted performance of 270 mutual funds during the 1985-1994 period. He concludes that the average US equity mutual fund under-performs by $1.94 \%$ per year.

These studies clearly pinpoint the weaknesses of the Ippolito study and advocate the use of multi-factor models to evaluate mutual fund performance. A further piece of evidence is provided by Carhart (1997). This influential study proposes the inclusion of a fourth factor, stock price momentum. Although the previous 3-factor model improves average CAPM pricing errors, it is not able to explain the cross-sectional variation in momentum-sorted portfolio returns. Therefore Carhart (1997) extends the Fama-French model by adding a fourth factor that captures the Jegadeesh \& Titman (1993) momentum anomaly. Using this 4factor model Carhart, Carpenter, Lynch and Musto (2000) report an average underperformance of $1.70 \%$ per year for domestic US funds.

Finally Ferson \& Schadt (1996) discuss the fact that fund managers may change their portfolios over time, based on observable information variables. All previous studies however calculate risk-adjusted performance using a fixed beta estimate for the entire sample period. If a manager really changes his portfolio risk over time, which is quite plausible, the previous approaches could lead to unreliable results. Therefore Ferson \& Schadt (1996) explore the added value of introducing time-variation in betas to existing mutual fund performance models. Conditioning on publicly available information leads to conditional performance measurement, while the previous models will be referred to as unconditional performance measurement. Using a sample of 67 US mutual funds during the 1968-1990 period, they document strong time-variation in fund betas. More importantly, the conditional model leads to a small out-performance for the average fund, while using the unconditional model the average fund under-performs. Thus, a simple adjustment to condition on public information questions the general results of mutual fund under-performance. Because of the rather small size of their sample however, one has to be careful in interpreting this result. In chapter 4 we will review the Ferson \& Schadt results using a sample of over 2400 funds.

All previous studies were performed using US databases. Evidence on European mutual funds is limited to only a few studies on individual countries. McDonald (1973) studied 8 French funds during the $1964-1969$ period. Using a single factor model he reported an insignificant out-performance for all 8 funds. Blake and Timmerman (1998) document evidence to support the under-performance of UK funds. By using a sample of over 2300 funds over the 1972-1995 period they find the average equity fund to under-perform by about $1.8 \%$ per year. Note that their study includes a size factor, but does not take into account book-to-market and/or momentum. Finally Dahlquist, Engström and Söderlind (2000) provide evidence of Swedish equity mutual fund performance. Using 126 equity funds for the 19921997 period they report an out-performance of $0.24 \%$ per year for regular equity funds. 
Interestingly, a second group of funds that was part of a public savings program (offering tax advantages) under-performed by $1.30 \%$ per year. These results were quite robust to the introduction of time-variation in betas. However, like Blake and Timmerman (1998), no book-to-market and/or momentum factor was included.

\subsubsection{Survivorship Bias}

A well-known bias that has plagued most mutual fund studies before the 90 's is called survivorship bias. Most commercially available mutual fund databases include only funds that are currently in operation. Funds that cease to report returns to the data provider are deleted from the database. ${ }^{7}$ This sounds logical, as clients normally are only interested in funds they can still invest in. For academic research this however creates a possible problem. As documented by for instance Blake and Timmerman (1998) and Carhart, Carpenter, Lynch and Musto (2000), funds that disappear primarily do so because of strong under-performance. Blake and Timmerman (1998) report a significant under-performance of $3.3 \%$ during the 12 months period preceding the termination date of a fund. Leaving out funds that ceased reporting returns makes the database one of survivors only. As funds that were deleted probably delivered bad performance, the remaining surviving funds create an average return figure that is too optimistic. Several US studies provided estimates for this survivorship bias, which is defined as the return on a portfolio of surviving funds minus the return on a portfolio containing all funds (including dead). Grinblatt and Titman (1989) estimate the bias to be between $0.1 \%$ and $0.3 \%$ per year. Malkiel (1995) uses a different sample, which leads to a significant survivorship bias of $1.4 \%$ per year. Elton, Gruber and Blake (1995) also find large biases of over $1 \%$ per year. Finally Carhart et al (2000) report a $0.17 \%$ bias for one-year samples, while the per annum bias for samples longer than 15-years is larger than $1 \%$.

Only two studies present evidence on the issue of survivorship bias in European databases. Dahlquist, Engström and Söderlind (2000) report a bias of $0.22 \%$ to $0.70 \%$ per year for Swedish funds. Blake and Timmerman (1998) find a bias of $0.30 \%$ per year for UK funds.

\subsubsection{Persistence}

Measuring mutual fund performance is always done in a historical setting. By comparing returns in the past to the returns on a set of relevant benchmarks we try to assess whether a fund was able to deliver superior returns. This however is only helpful if past performance is a predictor of future performance, implying a predictable pattern. In the Netherlands it is even

\footnotetext{
' Reasons why a fund stops reporting data to the database provider include the merger into another fund or a complete shutdown of the fund.
} 
compulsory by law to warn the investor that returns from the past are no guarantee for future returns. But still mutual fund companies prominently advertise their past performance in the popular press and fund brochures. This is of course only done if their fund performed well, compared to some benchmark or the peer group average return.

A number of US studies investigate whether mutual funds with an above average return in the past will also have an above average return in the future. Hendricks, Patel \& Zeckhauser (1993) and Brown \& Goetzmann (1995) find evidence of persistence in mutual fund performance over short-term horizons where Grinblatt \& Titman (1992) and Elton, Gruber, Das \& Blake (1996) document mutual fund return predictability over longer horizons. Carhart (1997) shows that this so called "hot hands" effect is mainly due to persistence in expense ratios and the pursuing of momentum strategies. Contrary evidence comes from Jensen (1969), who does not find predictive power for alpha estimates.

The importance of persistence analysis is stressed by Sirri and Tufano (1998) and Wermers (2001). The latter study provides a comprehensive overview on the predictability of mutual fund returns based on several fund characteristics. He finds that prior-year winning funds beat prior-year losing funds, during the following year by $2 \%$ per year, on a riskadjusted basis. These past winners experience cash inflows from investors that amount to 20$30 \%$ of total assets, in contrast to past losers, which experience cash outflows of $2-6 \%$ per year. Finally Zheng (1999) finds that this newly invested money is able to predict future fund performance, in that portfolios of funds that receive more money subsequently perform significantly better than those that lose money. The overall evidence on US funds indicates that the persistence of past winners continues for about 1 year, while the under-performance of past losers persists over a somewhat longer period. This raises an interesting question that has not been answered yet: why do poorly performing managers survive? Is it the case that closing or restructuring a fund is too expensive, or do these funds still deliver valuable services for their investors, which offsets their poor returns? This question may be a fruitful case for future research.

Persistence analysis on European funds is limited to two studies. Blake and Timmerman (1998) investigate UK funds for the 1972-1995 period. They sort funds into quartiles based on their abnormal performance over the previous 24 months. Then equalweighted portfolios comprising the best performers and worst performers were formed and held for one month. This procedure was carried out recursively to generate a time series of returns on the two portfolios. The results of this exercise point to the out-performance of the best performers portfolio, while the worst performers portfolio under-performed on a riskadjusted basis. Therefore Blake and Timmerman (1998) conclude that there is considerable persistence in abnormal returns, and that past abnormal returns do provide important information for selecting mutual funds. It should be noted here that the one-month revision period is in contrast with the more common procedure of revising the portfolios once a year. In chapter 5 we will review these UK results using the more common 1-year holding period, 
in combination with conditional performance models. Finally Grünbichler \& Pleschiutschnig (1999) investigate performance persistence by looking at mutual funds investing in the European region. They employ a database of 333 funds from 8 different European countries, investing in Europe for the 1989-1995 period. They report significant persistence in riskadjusted returns. However, their sample is not free of survivorship bias, which possibly influences the significance of their results.

\subsection{Style Analysis}

The third pillar of this thesis deals with style analysis. Style analysis of mutual funds is an important tool that seeks to help investors to understand a mutual fund's investment policy and objective. Before investing in a mutual fund an investor normally first tries to find out how this fund invests his money. For instance whether the fund invests domestically or internationally, or whether it focuses on large blue chip stocks or smaller companies. If the investor is bullish on small cap stocks he may want to browse the available fund universe to find a suitable fund that meets the small cap desire. An obvious starting point to screen the universe of mutual funds is the fund prospectus. Every US fund is obligated by the SEC to publish a prospectus that at least contains information on the funds investment style and expense ratio. Although the fund prospectus seems a sound source of information, recent research by DiBartolomeo and Witkowski (1997), Brown and Goetzmann (1997) and Kim, Shukla and Tomas (1999) presents evidence of serious misclassifications if self-reported investment objectives are compared to actual styles. For instance results reported by DiBartolomeo and Witkowski (1997) suggest that $31 \%$ of all US mutual funds are misclassified. According to the authors this has severe implications for investors. "For example, a fund that labels itself "income" but invests a large portion of its assets in small, growth-oriented stocks may have risk and return parameters that are inappropriate for a retired couple".

Possible reasons to deviate from a stated investment style include objective gaming or simply negligence. Especially the first, objective gaming, has gained widespread attention among investment professionals. Consider a fund that states to be in a lower risk class than it actually pursues. Using this strategy, the fund manager may be expected to perform better in comparison to the funds in his stated objective group. This obviously exposes its investors to a much higher risk-level than they are aware of. To avoid this, techniques to measure and analyze mutual fund styles are of paramount importance.

A popular approach that is therefore used for detecting mutual fund styles is returnbased style analysis (RBSA). Typically, the fund return is compared with the return on a number of selected passive style indices. The indices represent distinct investment styles within particular asset classes (e.g. value, growth, and small caps). Using regression analysis a 
mixture of indices is determined that has moved most with the fund. Style analysis thus is the construction of a portfolio of indices that best mimics the historical performance of a mutual fund.

Sharpe $(1988,1992)$ has proposed an econometric technique to conduct RBSA. This technique involves a constrained regression that uses several asset classes to replicate the historical return pattern of a portfolio. The constraints are imposed to enhance an intuitive interpretation of the coefficients. A non-linear regression analysis is proposed to arrive at point estimates for the portfolio weights. The ultimate idea is to check whether the estimated portfolio weights correspond with the targeted investment style of the mutual fund.

The point estimates for the portfolio weights only provide a limited picture of the information that is available in the historic fund returns. In addition to the point estimates, the asymptotic distribution function of the parameter estimates is helpful in determining the accurateness of the estimates. However, the constraints on the parameters make it less straightforward to arrive at the asymptotic distribution of the parameter estimates. Lobosco and DiBartolomeo (1997) propose approximate confidence intervals for the coefficients. However, these approximate confidence intervals still provide limited information as they do not allow for tests on multiple coefficients. In chapter 7 we propose a simulation approach to arrive at the asymptotic distribution of the parameter estimates

\subsection{Contribution of this Thesis}

\subsubsection{Structure}

In this thesis we provide a thorough analysis of the structure of the European mutual fund industry. Chapter 3 focuses on industry concentration, growth potential, distribution channels and fee structures. The main added value is the collection of recent information on the 6 most important European mutual fund markets and additionally comparing these to the US industry. In particular we identify the structural factors that are most crucial for the future development of the European mutual fund industry. The influence of this structure on the performance of the European industry will then be tested throughout the remainder of this thesis.

\subsubsection{Performance}

The added value this thesis delivers with respect to performance measurement of mutual funds, lies both in the use of self-collected databases of European funds and the development of more elaborate performance models. This allows us to provide out-of sample tests for results found by US mutual fund studies. Furthermore we review and extend existing research 
on European funds using better data and, more importantly, richer model specifications. More specifically, in chapter 4 we perform a comprehensive assessment of existing mutual fund performance models using a newly introduced US mutual fund database. The main goal of that chapter is to determine which model is best suitable to measure mutual fund performance. The results of this assessment will then be used in Chapter 5 and 6 to measure European mutual fund performance. In addition this thesis delivers new evidence on survivorship bias and the persistence in mutual fund returns for European mutual fund markets.

\subsubsection{Style Analysis}

The final contribution relates to the improvement of mutual fund style estimation techniques. By using a combination of an optimization algorithm and the bootstrapping technique, we improve the results taken from return-based style analysis (RBSA). Using this additional information we analyze the mutual fund misclassification phenomenon. Our empirical work both differentiates the US evidence and provides the first comprehensive analysis of UK fund misclassification. In addition we provide significant new evidence on the impact of survivorship bias on the fund misclassification phenomenon. 



\section{Chapter 3}

\section{Comparing the European and the US Mutual Fund Industry ${ }^{8}$}

\subsection{Introduction}

In the last decade the mutual fund industry has grown dramatically. In the United States the market has grown from about $\$ 0.7$ trillion in 1988 to $\$ 4.5$ trillion in 1997 . The number of funds expanded at the same pace from 1100 in 1988 to 6900 in $1997 .^{9}$ Currently, the number of mutual funds is roughly $60 \%$ larger than the number of listed securities. The importance of mutual funds in society justifies the tremendous amount of studies published in the financial press and academia. Like mentioned in chapter 2 , the issues that get most attention are timing and selection abilities, benchmark sensitivity, performance persistence, and survivorship bias. See for example, among many others, Brown et al. (1992) and Carhart (1997). and Grinblatt and Titman (1989).

All these studies typically focus on the United States, where historic data are easily available and the market is more or less in a mature phase. In contrast to the United States, the European market has never been studied comprehensively, although several authors studied individual countries. (See for example Dermine (1992), McDonald (1973), Shukla and Imwegen (1995), and Ward and Saunders (1976)).

This chapter is intended to fill this gap and present a thorough view on the European mutual fund industry as a whole. To explain the behavior of the European mutual fund industry and the demand for their services, it is essential to incorporate the organizational

\footnotetext{
${ }^{8}$ This Chapter is based on R. Otten and M. Schweitzer, 'A Comparison between the European and US Mutual Fund Industry', Managerial Finance, Vol. 28, no. 1, 2002, pp 14-35

'Source FEFSI 1999
} 
characteristics of the industry as well. In the literature there is a general lack of studies on these characteristics. A few exceptions to this are Chordia (1996), Tufano and Sevick (1997), and Walter (1998). These authors describe and analyze issues as fee structures, board structures and globalization. In general they find that organizational characteristics do indeed influence the performance.

In this chapter we study the behavior of the European mutual fund industry, compare it with the American mutual fund market and finally provide a first test of the performance of European mutual funds. In chapter 4 we consider more elaborate performance models, which will then be used in chapter 5 , to re-evaluate European mutual fund performance. Formally, we test the hypothesis whether the European mutual fund industry has characteristics like the American mutual fund industry using a traditional structure-conduct-performance (SCP) paradigm. (See Mueller and Burkhard (1999), and Shaffer (1994)) The set-up of this chapter is as follows. In section 3.2 we provide an overview of the structure of the European mutual fund industry and compare it with the situation in the United States. In section 3.3 we discuss the conduct in the industry and in section 3.4 we bring the structure and conduct together and carry out a performance analysis of the individual mutual funds. Section 3.5 concludes the chapter.

\subsection{The Structure of the Mutual Fund Industry in Europe and the United States}

By the end of 1997 there were \$2.1 trillion of assets under management in European openended funds. These were split among 17,000 funds promoted by 1,400 management groups. This means that the European industry is the second largest in the world and accounts for $29 \%$ of world fund assets. It is only surpassed by the American industry, which had $\$ 4.5$ trillion assets under management divided among 700 fund groups by the end of $1997 .{ }^{10}$ In this section we focus on the differences between the structure of the European market and the American mutual fund market. We will first analyze the demand for mutual fund services, followed by the supply and finish with the costs involved. As a proxy for the European market we use the 6 most important European mutual fund markets. Together they account for $85 \%$ of total mutual fund assets in Europe." Table 3.1 presents some of the major characteristics of the two continents and the individual countries.

\footnotetext{
${ }^{10}$ See FEFSI Statistics 1998 and Morningstar

"We exclude Luxembourg with $\mathbf{\$ 3 8 1}$ billion in assets as it mainly serves as an offshore center, which is the result of fiscal and regulatory advantages. The domestic market itself is rather small.
} 
Table 3.1: Characteristics of Major Mutual Fund Markets

Total assets Number of Average Asset allocation (in \%)

\begin{tabular}{lrrrrrrrr} 
& & Funds & Size & \multicolumn{2}{c}{ Equity Bond } & \multicolumn{2}{c}{ Balanced Money } & Others \\
\hline United States & $\mathbf{4 , 4 6 5}$ & $\mathbf{6 , 9 0 0}$ & $\mathbf{6 4 7}$ & $\mathbf{5 3 . 0}$ & $\mathbf{1 9 . 5}$ & $\mathbf{2 . 8}$ & $\mathbf{2 4 . 1}$ & $\mathbf{0 . 6}$ \\
& & & & & & & & \\
Europe & $\mathbf{1 , 3 6 0}$ & $\mathbf{1 0 , 2 6 9}$ & $\mathbf{2 2 6}$ & $\mathbf{3 1 . 8}$ & $\mathbf{3 0 . 4}$ & $\mathbf{1 1 . 3}$ & $\mathbf{2 5 . 7}$ & $\mathbf{0 . 8}$ \\
$\quad$ France & 505 & 5,836 & 87 & 13.6 & 27.2 & 18.7 & 40.4 & 0.1 \\
United Kingdom & 237 & 1.455 & 163 & 85.8 & 6.1 & 7.6 & 0.5 & 0.0 \\
Italy & 210 & 626 & 337 & 20.4 & 44.0 & 6.3 & 25.0 & 4.3 \\
Spain & 179 & 1456 & 123 & 10.5 & 40.9 & 11.1 & 37.5 & 0.0 \\
Germany & 148 & 717 & 207 & 37.9 & 48.2 & 2.8 & 11.1 & 0.0 \\
Netherlands & 78 & 179 & 440 & 53.8 & 30.2 & 5.7 & 10.1 & 0.2
\end{tabular}

Notes: This table presents the characteristics of the major European mutual fund markets and the United States. All figures are obtained from FEFSI and are of December 31, 1997. The first column presents the total market value (billion US dollar). The second column the number of funds, the third column the average size and the last 5 columns the asset allocation of all mutual funds as percentage of total assets.

Table 3.1 confirms that the mutual fund industry in the United States is much larger than the European industry. In contrast, the number of funds is much higher in Europe, which results in a smaller average size of the individual funds in Europe. The funds in the United States are with an average fund size of 647 million dollar almost three times as big as in Europe where funds have an average size of 226 million US dollar. Even within Europe there are some differences as the average size of the funds varies between 87 million US dollar in France to 440 million US dollar in the Netherlands. Another difference between the continents is clear in the asset allocation. In the United States more than $50 \%$ of the funds are equity investors, whereas the percentage in Europe is less than a third. This is probably due to the lower demand for equity-related products in Europe, and definitely not to the shortfall of the supply of funds. We believe that a different equity culture, strong presence of banks and a different pension system explain part of the lower demand. ${ }^{12}$

Figure 3.1 gives some insight into the development of the demand from individual investors for equity mutual funds. It presents the growth of market capitalization of the equity mutual funds in Europe and the United States between 1992 and $1997 .{ }^{13}$ While, clearly the industry is growing in both continents industry growth in the United States has been sharper than in Europe. Europe thus is not only lagging behind the United States in absolute size, but

\footnotetext{
${ }^{12}$ We won't explore these issues in more detail, but others have researched them. See for example Poterba, Venti, and Wise (1998).

${ }^{13}$ This statistic is not only influenced by the demand for mutual fund services, but also by the bull market that occurred at the stock exchanges during the sample period. When we take the bull market into account we can show that the demand for mutual fund services is still growing rapidly. The results of these tests are available upon request.
} 
Figure 3.1: Growth in Asset Sizes for Equity Funds 1992 - 1997

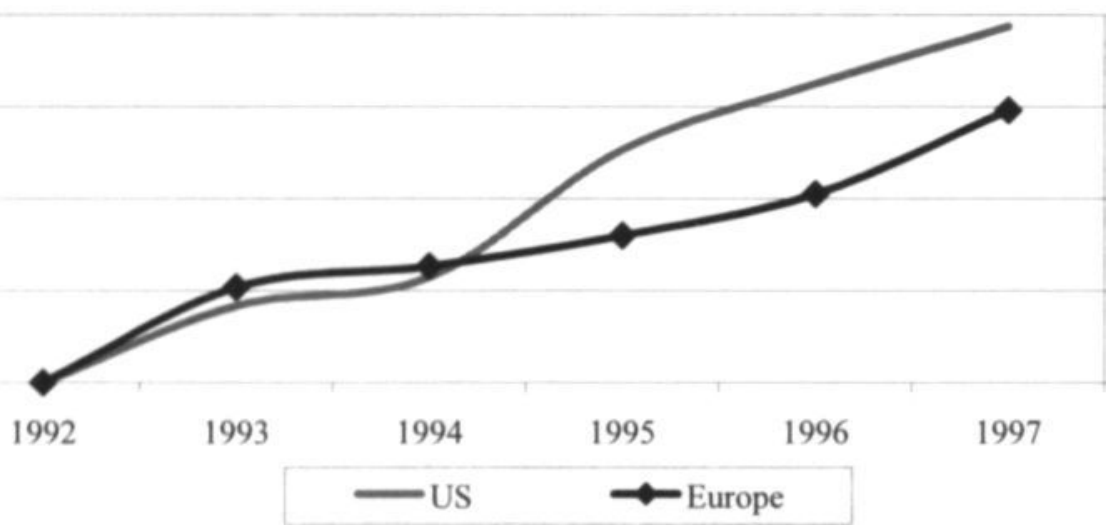

Notes: This figure presents the market capitalization of the equity mutual funds as an index figure with 1992 as the base year. Size in billion U.S. Dollar.

Figure 3.2: Growth in Equity Mutual Funds 1992-1997

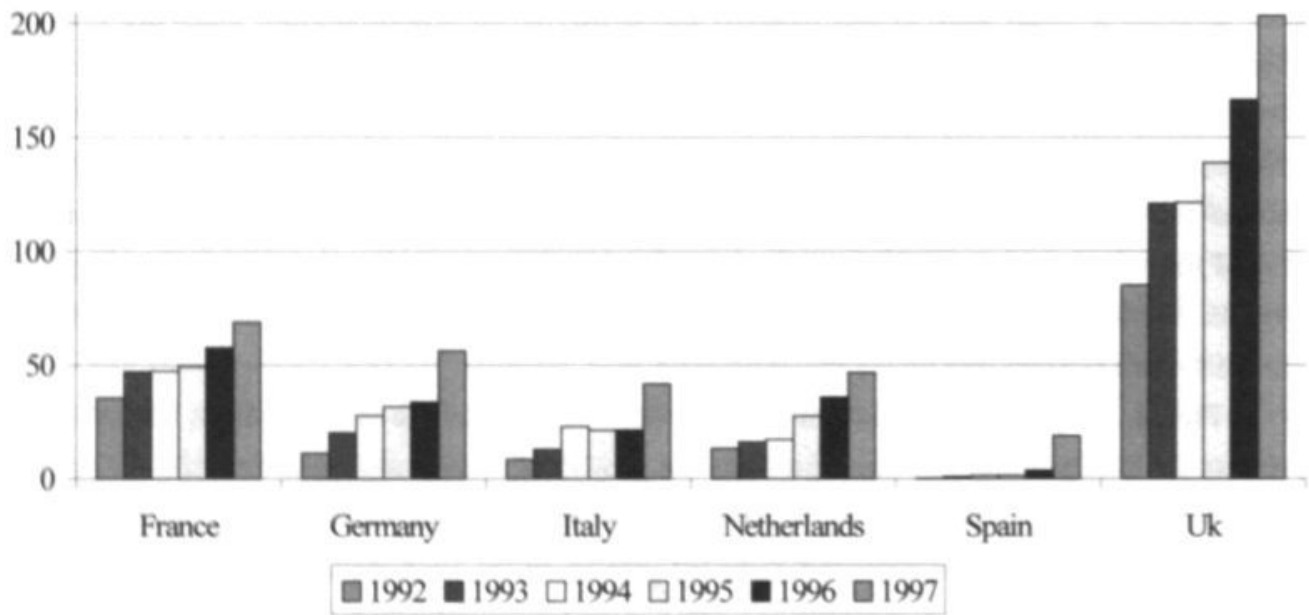

Notes: This figure presents the absolute figures (in billion U.S. Dollar) of the market capitalization of the equity mutual funds for individual European countries. 
also in growth. To put the picture in perspective, figure 3.2 presents equity mutual fund sizes for the individual European countries over time and shows that some markets are growing very rapidly whereas others are growing at a much lower pace. That is, the United Kingdom and France have the largest mutual fund sector, but also have lower growth rates than the United States. The smaller European countries have growth rates up to $8000 \%$. For instance, in countries like Spain and Italy, where mutual funds did not exist at all in the beginning of the sample period, rapid growth is present. Thus, despite the lower growth of the European industry, we see that some underdeveloped mutual fund industries are catching up very quickly, and that the demand for mutual fund services is increasing.

Although mutual funds are less important in Europe than in the United States, it is not necessarily true that Europeans have less exposure to the equity market. They can also purchase equities themselves or through other institutions like pension funds and insurance companies. ${ }^{14}$ Table 3.2 presents a statistic that indicates the importance of mutual funds at their domestic equity market. The statistic is calculated as the total market value of all equity mutual funds divided by the market capitalization. ${ }^{15}$ The 1997 figure for the United States is $26 \%$, which is roughly two-and-a-half times as big as the average European figure. Therefore the European mutual fund sector is indeed not as important as its American counterpart indicating that individuals possibly purchase equities through other channels. Finally the table shows that the percentage increased through time both in the United States and in Europe.

Table 3.2: Equity Mutual Funds as a Percentage of Total Market Value

\begin{tabular}{lcccccc}
\hline & $\mathbf{1 9 9 2}$ & $\mathbf{1 9 9 3}$ & $\mathbf{1 9 9 4}$ & $\mathbf{1 9 9 5}$ & $\mathbf{1 9 9 6}$ & $\mathbf{1 9 9 7}$ \\
\hline United States & $\mathbf{1 6 \%}$ & $\mathbf{2 0} \%$ & $\mathbf{2 2} \%$ & $\mathbf{2 6} \%$ & $\mathbf{2 8} \%$ & $\mathbf{2 6} \%$ \\
& & & & & & \\
Europe & $\mathbf{6 \%}$ & $\mathbf{8} \%$ & $\mathbf{8} \%$ & $\mathbf{8} \%$ & $\mathbf{8} \%$ & $\mathbf{1 1} \%$ \\
$\quad$ France & $13 \%$ & $12 \%$ & $13 \%$ & $11 \%$ & $11 \%$ & $11 \%$ \\
$\quad$ United Kingdom & $10 \%$ & $11 \%$ & $11 \%$ & $11 \%$ & $10 \%$ & $11 \%$ \\
Italy & $8 \%$ & $9 \%$ & $12 \%$ & $11 \%$ & $9 \%$ & $13 \%$ \\
Spain & $0 \%$ & $1 \%$ & $1 \%$ & $1 \%$ & $2 \%$ & $9 \%$ \\
Germany & $3 \%$ & $5 \%$ & $7 \%$ & $7 \%$ & $6 \%$ & $8 \%$ \\
Netherlands & $6 \%$ & $8 \%$ & $7 \%$ & $9 \%$ & $9 \%$ & $10 \%$ \\
\hline
\end{tabular}

Notes: This table presents the total market size of the equity mutual funds as percentage of the total market size at the end of the year. Sources are FEFSI and Datastream

\footnotetext{
${ }^{14}$ In 1997 mutual funds possessed a $14.7 \%$ stake in total European retail savings, deposits $36.2 \%$, bond investments $8.7 \%$, while direct equity investments amounted to $9.8 \%$ and investments through life and pension funds up to $30.6 \%$. Source: Datamonitor.

${ }^{15}$ The market capitalization is collected from Datastream and represents the total market including all listed mutual funds itself.
} 
Besides the demand for mutual fund services the supply of the product by financial institutions is also important. Mutual funds are usually part of a mutual fund group, which gives customers the possibility to switch easily (and often with lower costs) between funds. This is true both for the United States and Europe. However, if fund groups become too big, they might control the market for financial services, which might have a negative effect on the performance of the industry. In both Europe and the United States the top 5 providers of mutual fund services own less than $20 \%$ of the market. This indicates that Europe and the Unites States are roughly equal regarding the competition between fund groups. In table 3.3, however, we also present the statistic per country. The table shows that the percentages are much higher for all individual countries, except for the United Kingdom. This means that within single European countries individual fund groups dominate their domestic market. This might have a negative influence on the conduct and on the performance of the industry.

Turning now to the price investors pay for the services that mutual funds offer we assume that the management fee paid represents the price of the product. Even though legal structures differ slightly between countries, the basic fee system is similar now. That is, the individual pays a management fee that the asset manager receives to manage the portfolio. Table 3.4 presents the fees charged by mutual funds. Besides the figures for the two continents, we split the sample up by country (panel A) and by investment style (panel B). The average fee in the United States is slightly higher than the average in Europe indicating that with respect to the fee structure the continents do not differ much. However, the difference in maximum and minimum fees is larger in the United States. Europe has a higher minimum fee and a lower maximum fee. This might indicate that most European funds follow the same investment strategy, whereas in the United States funds have strategies ranging from pure index funds to highly active strategies, which might lead to a more pronounced differentiation in fees. The results of the individual European countries and the different investment styles, presented in panel $\mathrm{A}$ and $\mathrm{B}$, confirm these findings. 
Table 3.3: Concentration Ratios

\begin{tabular}{|c|c|}
\hline United States & $18 \%$ \\
\hline Europe & $19 \%$ \\
\hline France & $62 \%$ \\
\hline Germany & $62 \%$ \\
\hline Italy & $43 \%$ \\
\hline Netherlands & $60 \%$ \\
\hline Spain & $48 \%$ \\
\hline United Kingdom & $20 \%$ \\
\hline \multicolumn{2}{|c|}{$\begin{array}{l}\text { Notes: This table presents the } 1997 \text { concentration ratio } \\
\text { calculated as the market value of the five largest fund } \\
\text { groups as part of the total mutual fund market. Sources are } \\
\text { Datamonitor, Morningstar and Lipper. }\end{array}$} \\
\hline
\end{tabular}

Table 3.4: Management Fees

\begin{tabular}{|c|c|c|c|c|c|c|}
\hline & \multicolumn{2}{|c|}{ Average } & \multicolumn{2}{|c|}{ Minimum } & \multicolumn{2}{|c|}{ Maximum } \\
\hline United States & \multicolumn{2}{|c|}{1.4} & \multicolumn{2}{|c|}{0.2} & \multicolumn{2}{|c|}{17.7} \\
\hline Europe & \multicolumn{2}{|c|}{1.2} & \multicolumn{2}{|c|}{0.1} & \multicolumn{2}{|c|}{3.0} \\
\hline \multicolumn{7}{|l|}{ Panel A: } \\
\hline France & \multicolumn{2}{|c|}{1.2} & \multicolumn{2}{|c|}{0.3} & \multicolumn{2}{|c|}{3.0} \\
\hline Germany & \multicolumn{2}{|c|}{0.8} & \multicolumn{2}{|c|}{0.5} & \multicolumn{2}{|c|}{2.0} \\
\hline Italy & \multicolumn{2}{|c|}{2.0} & \multicolumn{2}{|c|}{0.1} & \multicolumn{2}{|c|}{3.0} \\
\hline Netherlands & \multicolumn{2}{|c|}{0.5} & \multicolumn{2}{|c|}{0.4} & \multicolumn{2}{|c|}{1.0} \\
\hline Spain & \multicolumn{2}{|c|}{2.0} & \multicolumn{2}{|c|}{0.5} & \multicolumn{2}{|c|}{3.0} \\
\hline United Kingdom & \multicolumn{2}{|c|}{1.2} & \multicolumn{2}{|c|}{0.3} & \multicolumn{2}{|c|}{2.0} \\
\hline Panel B: & US & $\mathrm{EU}$ & US & $\mathrm{EU}$ & US & $\mathrm{EU}$ \\
\hline Aggressive growth & 1.7 & & 0.7 & & 6.4 & \\
\hline Growth & 1.4 & 1.2 & 0.3 & 0.4 & 11.9 & 2.0 \\
\hline Income & 1.3 & 1.2 & 0.5 & 0.5 & 2.3 & 2.0 \\
\hline Growth/income & 1.2 & 1.1 & 0.2 & 0.3 & 17.7 & 2.0 \\
\hline Small Caps & 1.5 & 1.2 & 0.2 & 0.5 & 7.3 & 2.5 \\
\hline
\end{tabular}

Notes: This table shows the average, minimum, and maximum management fees in percentages charged by the individual mutual funds in 1997. Sources are Morningstar, S\&P Micropal, ABN-AMRO, Financial Times, and Hoppenstedt. We do not consider back and front-end fees. 
Recent research by Fitzrovia International, a London-based fund research firm, showed that the reported costs for the UK-funds are not the same as the true costs because administration costs, legal and audit fees are not included. ${ }^{16}$ The company thinks that the best guess would be to double the reported fees to get the true Total Expense Ration (TER). Currently they are studying other European countries as well, but the assumption might be that this relation holds for these countries as well. The Investment Company Institute (ICI) in Washington D.C. has studied the situation in the Unites States and found that the TERs are declining. Because however the SEC closely monitors US fees, as they appear in a fund's prospectus, the difference between the true TER and the one reported will not be that large for the US market. The European fees should however be interpreted carefully.

In sum, we conclude from the description of the structure that the European mutual fund sector is growing rapidly, but that the importance in the financial market is still not as high as in the United States. This suggests that continued growth of mutual fund services in Europe is possible. An important institutional factor that might influence the speed of the growth is the dominance of the top five fund groups in the individual countries. They control the market, which reduces competition and possibly leads to higher entry barriers. In the next section we analyze the actual conduct of the funds and in section 3.4 the performance of the funds.

\subsection{Conduct in the Industry}

The conduct of the mutual fund industry will be described and discussed along two lines. First we look at the distribution channels the funds use to sell their products and secondly how past performance is presented to the general public.

Table 3.5 shows the importance of a specific distribution channel in Europe and the United States. The table clearly shows a big difference between the two continents. European mutual funds predominately use banks as the major distribution channel with a market share of $53 \%$, whereas in the United States only $8 \%$ is sold through banks. The differences between individual European countries are interesting as well (not reported in the table). In most countries the percentage of banks is bigger than $50 \%$. The United Kingdom is the only European country where banks have only $10 \%$ of the market. This means that the United Kingdom and the United States have similar characteristics in this respect. As banks are actually not used in those two countries it means that other channels are more important. In the United Kingdom the distribution of mutual fund services is predominately done through independent agencies. In the United States, brokers and direct sales are the most used channels. Besides these channels we see, especially in the United States, an increasing trend

\footnotetext{
${ }^{16}$ See Economist (1999) for details.
} 
towards the provision of mutual fund services through the Internet. Especially firms like Fidelity and Schwab are leading this development.

Table 3.5: Distribution Channels

\begin{tabular}{lcc}
\hline & Europe & United States \\
\hline Banks & $53 \%$ & $8 \%$ \\
Brokers & $11 \%$ & $40 \%$ \\
Direct sales & $9 \%$ & $32 \%$ \\
Other & $27 \%$ & $20 \%$ \\
\hline Notes: This table presents the use of a distribution channel \\
as percentage of the total market. The category 'Other' \\
includes insurance companies, and independent sales forces. \\
Sources: EFID, Datamonitor, Investment Company \\
Institute.
\end{tabular}

The continents also differ when we look at the use of performance statistics. In the United States league tables are widely published and used by individual investors. For example, Sirri and Tufano (1998) show that when funds receive a 4 or 5-star ranking from Morningstar (based on past performance) money inflow increases in the following year. According to the popular press in Europe, individuals seem to value service (e.g. being friendly and accurate) at least as much as performance in terms of returns relative to the benchmark. This could explain the strong position of banks. However, we see that league tables are currently getting more attention in the European press as well. For instance, S\&P Micropal and Morningstar Europe publish monthly performance rankings through several outlets. This will possibly lead to money in- and outflows, based on these publications. As far as we know a European study on this issue has not been carried out, but it would be a fruitful venue for further research.

Table 3.6 presents a summary of the analysis of the structure and conduct of the industry, based on the data and the analysis in sections 3.2 and 3.3. It restates the conclusion that the European mutual fund industry is still lagging the American industry. Furthermore, we found some indication of less competition in Europe, which might possibly diminish performance. In the next section we compare the performance between the continents and see whether there exists a pattern related to the structure and conduct in the industry. 
Table 3.6: Comparison between the United States and Europe

\begin{tabular}{|c|c|c|}
\hline & United States & Europe \\
\hline \multicolumn{3}{|c|}{ Structure of the Mutual Fund Market } \\
\hline Total assets (trillion \$) & 4.5 & 1.4 \\
\hline Average fund size (million \$) & 650 & 230 \\
\hline$\%$ invested in equity funds & High & Low $^{17}$ \\
\hline Market importance & High & Low \\
\hline Concentration & Low & High within countries \\
\hline Costs & High & Lower $^{18}$ \\
\hline \multicolumn{3}{|l|}{ Conduct of the Mutual Funds } \\
\hline Distribution & Direct channels & Banks \\
\hline Publicity/press coverage & High & Lower \\
\hline \multicolumn{3}{|c|}{$\begin{array}{l}\text { Notes: The table shows the summary of the analysis of the structure and the conduct of the } \\
\text { industry. It compares the situation in the United States and Europe. The classification is based on } \\
\text { sections } 3.1 \text { and } 3.2 \text {. }\end{array}$} \\
\hline
\end{tabular}

\subsection{Performance of the Mutual Fund Industry}

In this section we use the third step of the SCP paradigm to study the effects of the structure and conduct on the performance in the industry. The SCP is a framework developed in organizational literature, which focuses on the product and production efficiency (see Scherer and Ross (1990) for more details). Traditionally the SCP paradigm measures the performance along the lines of 1 ) Production and allocation efficiency, 2) Progress, 3) Full employment and 4) Equity. In contrast, the finance literature always uses stock market returns and asset pricing models to measure performance. As the product of a mutual fund is the return on the invested portfolio, using stock market returns as our performance measure accommodates both strands of the literature. This gives us an opportunity to compare the performance of mutual funds in the two continents and link it to the structure and conduct in the industry.

The remainder of this section is split in 7 sub-sections, which all highlight a particular issue related to the performance. In section 3.4.1 we discuss the data we use to test the performance; section 3.4 .2 presents the summary statistics of the performance; in section 3.4.3 we analyze the development through time of the performance; in 3.4 .4 we correct for asset allocations; in 3.4.5 we test for the influence of fees on performance; 3.4.6 takes a

\footnotetext{
${ }^{17}$ Except United Kingdom

${ }^{18}$ Except Italy
} 
detailed look at the under-performance of European index funds and finally in section 3.4 .7 we explore the out-performance of small cap funds.

\subsubsection{Data}

We use monthly logarithmic total returns for 506 European open-ended mutual funds and 2096 US open-ended mutual funds from January 1991 to December $1997 .^{19}$ We restrict our sample to purely domestic equity funds with at least 24 months of data. That is, we exclude balanced and guaranteed funds and equity funds that invest internationally. Limiting the sample size along these lines gives us an excellent possibility to compare the relative performance of the different mutual fund industries. If we include all existing funds we would have to correct for country allocation, exchange rate policies, and other legal obstructions before we could compare the relative performance.

To calculate relative performance we use the following local benchmarks to correct for market developments: 1) CAC for France, 2) DAX for Germany, 3) Mibtel for Italy, 4) AEX for The Netherlands, 5) FTSE All for the United Kingdom, and 6) the S\&P500 for the United States. We collect all indices on a total return basis, which means we reinvest all dividends. It is well known that the market for small stocks usually has different performance characteristics than the main market. As our sample also includes funds that invest in small caps we use a small cap index as the benchmark for these funds. For France we use the Midcac, for Germany the Datastream Small Companies Germany, for the Netherlands the Midcap index, for the United Kingdom the Hoare Govett Small Company index and for the United States the Russell 2000. We use the mid-cap indices for France and the Netherlands, as they represent the actual investment behavior of the funds better than the actual small cap indices (based on fund holdings). For Italy we don't need a small cap benchmark, as there are no funds concentrating on small companies.

To obtain information on the characteristics of the individual equity funds we use several sources: Standard\&Poor's Micropal (France, Italy), Hoppenstedt Fondsführer 1997 (Germany), ABN-AMRO Beleggingsinstellingen (Netherlands), Unit Trust Yearbook 1997 (United Kingdom), and Morningstar (United States). We gather data for several characteristics of each mutual fund: fund type or investment style, total return, size, and fees. Within a country we divide all funds using stated investment styles to test whether this yields differences in performance. Total return data are collected from Datastream International, S\&P Micropal and Morningstar.

In chapter 2 we addressed the possible influence of survivorship bias. Leaving out non-surviving funds might lead to an over-estimation of average fund returns, like for

\footnotetext{
${ }^{19}$ For Spain no comprehensive return data was available.
} 
example Brown et al. (1992) point out. We are confident that the data for Germany and the Netherlands are largely free of survivorship bias as Hoppenstedt fundguide for Germany and Koedijk et al. (1998) for the Netherlands studied these funds. For the United Kingdom we were able to identify dead funds through the Unit Trust Yearbook 1997. Dead Italian funds could be found through Datastream, while our source for French data, S\&P Micropal, was unable to provide data on dissolved funds. The main source of US fund data used in this chapter, Morningstar, releases the information on non-surviving funds only at very high costs, for a limited history. In chapter 4 and 6 however, we use a recently launched US mutual fund database by CRSP, which is survivorship bias free. This enables us to assess the influence of leaving out dead funds on US mutual fund performance measurement. This chapter mainly serves as a first exploration of the European fund industry.

\subsubsection{Summary Statistics}

To get an overview of the data we start our performance analysis with the presentation of table 3.7. It provides summary statistics and fund characteristics together with the performance of the relevant benchmarks. First of all we see that the number of domestic equity funds differs between countries. Whereas the United Kingdom has a total number of 304 domestic equity funds, the Netherlands has only 9 such funds. What is more important, however, is to look at the size of the European funds relative to their American counterparts. While the average European equity fund has about 300 million US dollars in assets, the average American fund amounts to 757 million US dollars. Furthermore, the average size of a European index fund is equal to 57 million US dollars, which is relatively small. ${ }^{20}$ Table 3.7 also gives a first indication of the performance of the funds. It presents unadjusted annual mean returns and standard deviations for each class of funds. We see that during the whole sample period (1991-1997) the Dutch mutual funds generated the highest annual return (20.6\%) with the second lowest standard deviation of $13.9 \%$. In contrast French mutual funds earned only $11.1 \%$ on an annul basis, which was the lowest return in the sample. U.K., Italian and German funds earned about the same rates of return, but the last two had a wider dispersion of returns, resulting in higher standard deviations. If we compare these statistics with the returns of the local benchmarks we see that, on average, mutual funds under-perform in most countries. On investment style level we find that in 3 out of 5 countries, small cap funds out-perform their relevant benchmark.

${ }^{30}$ Gruber (1996) reports that the average US index fund has $\mathbf{\$ 3 6 8}$ million in assets. 
Table 3.7: Summary Statistics of Individual Countries 1991-1997

\begin{tabular}{|c|c|c|c|c|c|}
\hline & $\mathbf{n}$ & $\mu$ & $\sigma$ & Size & Costs \\
\hline \multicolumn{6}{|l|}{ France } \\
\hline Growth & 55 & 11.1 & 14.3 & 396 & 1.1 \\
\hline Index & 20 & 10.0 & 17.3 & 65 & 1.2 \\
\hline Smaller Companies & 24 & 11.8 & 14.3 & 81 & 1.3 \\
\hline Tetal & 99 & 11.1 & 14.8 & 258 & 1.2 \\
\hline $\mathrm{CAC} 40$ & & 11.7 & 17.8 & & \\
\hline Midcac & & 7.5 & 17.7 & & \\
\hline \multicolumn{6}{|l|}{ Germany } \\
\hline General & 46 & 13.2 & 15.6 & 369 & 0.8 \\
\hline Growth & 5 & 10.7 & 16.2 & 125 & 0.8 \\
\hline Income & 2 & 13.7 & 16.5 & 660 & 1.0 \\
\hline Smaller Companies & 4 & 10.2 & 13.6 & 121 & 0.9 \\
\hline Total & 57 & 12.8 & 15.5 & 335 & 0.8 \\
\hline DAX & & 12.4 & 16.2 & & \\
\hline Datastream Smcos & & 3.1 & 10.2 & & \\
\hline \multicolumn{6}{|l|}{ Italy } \\
\hline Italian equity & 21 & 11.8 & 15.2 & 261 & 2.0 \\
\hline Italian specialist & 16 & 13.1 & 17.6 & 223 & 1.8 \\
\hline Total & 37 & 12.3 & 16.1 & 242 & 2.0 \\
\hline Mibtel & & 14.0 & 24.0 & & \\
\hline \multicolumn{6}{|l|}{ Netherlands } \\
\hline Growth & 5 & 20.6 & 13.2 & 500 & 0.6 \\
\hline Index & 3 & 20.5 & 15.1 & 50 & 0.4 \\
\hline Smaller Companies & 1 & 21.2 & 12.9 & 505 & 0.6 \\
\hline Total & 9 & 20.6 & 13.9 & 350 & 0.5 \\
\hline AEX & & 21.5 & 14.4 & & \\
\hline Midcap & & 22.9 & 15.9 & & \\
\hline \multicolumn{6}{|l|}{ United Kingdom } \\
\hline Growth/Income & 79 & 12.4 & 13.1 & 326 & 1.1 \\
\hline Income & 72 & 12.6 & 13.3 & 260 & 1.2 \\
\hline Growth & 102 & 12.8 & 13.1 & 215 & 1.3 \\
\hline Smaller Companies & 51 & 13.1 & 13.5 & 222 & 1.3 \\
\hline Total & 304 & 12.7 & 13.2 & 256 & 1.2 \\
\hline FTALL & & 14.1 & 13.1 & & \\
\hline Hoare Govett Smcos & & 11.6 & 14.5 & & \\
\hline \multicolumn{6}{|l|}{ United States } \\
\hline Aggressive Growth & 103 & 17.1 & 18.9 & 1027 & 1.7 \\
\hline Growth & 937 & 17.5 & 15.4 & 682 & 1.4 \\
\hline Income & 144 & 17.6 & 12.1 & 781 & 1.3 \\
\hline Growth/Income & 499 & 18.2 & 13.5 & 1175 & 1.2 \\
\hline Smaller Companies & 413 & 18.2 & 17.9 & 345 & 1.5 \\
\hline Total & 2096 & 17.8 & 15.4 & 757 & 1.4 \\
\hline \multicolumn{2}{|l|}{ S\&P 500} & 17.6 & 12.4 & & \\
\hline \multicolumn{2}{|l|}{ Russel 2000} & 18.7 & 13.7 & & \\
\hline $\begin{array}{l}\text { Notes: This table repo } \\
\text { reinvestment of all distri } \\
\text { sizes are presented in m } \\
\text { presented as a percentag }\end{array}$ & $\begin{array}{l}\text { ary stati } \\
\text { dd based } \\
\text { dollars }\end{array}$ & $\begin{array}{l}n \text { the } f \\
\text { cal curr }\end{array}$ & $\begin{array}{l}\text { Ir samp } \\
\text { I return } \\
\text { costs ar }\end{array}$ & $\begin{array}{l}\text { return d. } \\
\text { of exper } \\
\text { tted in th }\end{array}$ & $\begin{array}{l}\text { nnualized } \\
\text { e average } \\
\text { olumn an }\end{array}$ \\
\hline
\end{tabular}

\subsubsection{Development through Time}

In sections 3.2 and 3.3 we focused on the structure and conduct of the industry, and saw a trend towards an increased importance of both the European and US mutual fund sector. We 
now turn to the performance of the industry and test whether this trend has influenced the observed performance in section 3.4.2. We analyze the development by presenting the annualized difference between the fund performance and the return on the relevant benchmark (without correcting for risk or asset allocation) using a 36-month moving window. ${ }^{21}$

In line with earlier results, figure 3.3 shows that both European and US mutual funds, on average, under-perform their relevant benchmarks. It also points out that the performance in the United States has dropped during the sample period, whereas the performance of the European mutual fund industry has remained relatively constant. The averages, however, are not significantly different from each other, as standard errors around the trend are roughly $3 \%$.

Figure 3.3: Relative returns of European and US Mutual Funds Through Time

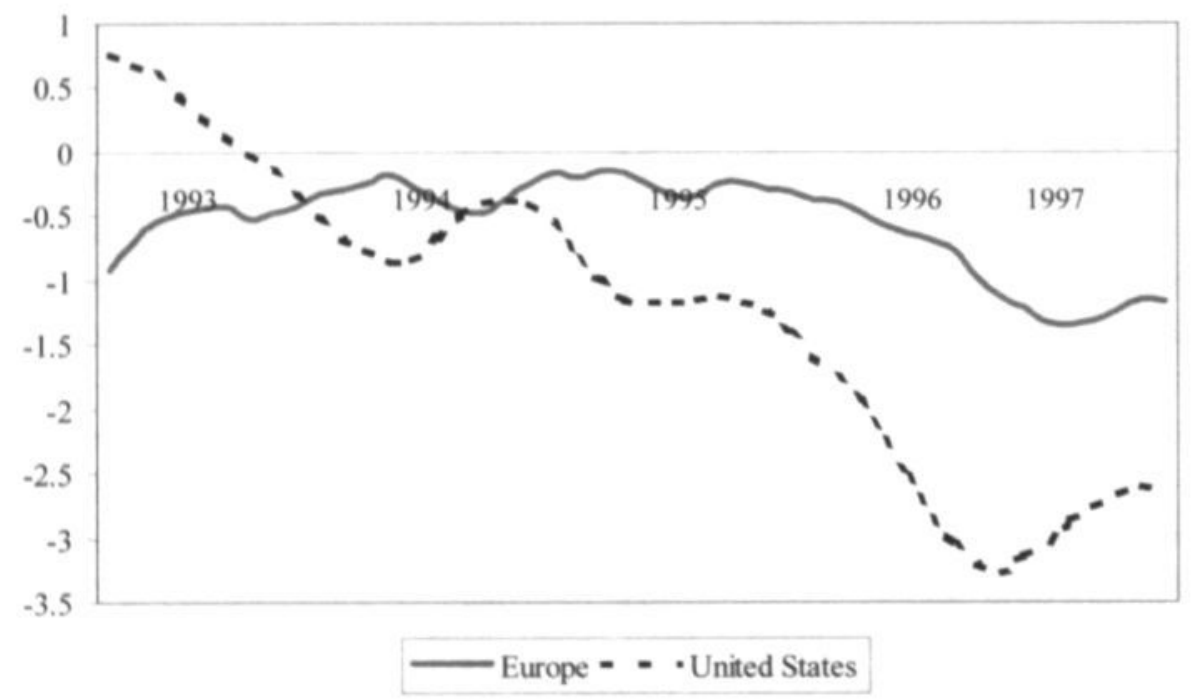

Notes: This figure gives the development of the relative returns in percentages per year (fundbenchmark) for both Europe and the United States. Plotted are the $\mathbf{3 6}$ month moving averages for the $1991-1997$ period. All returns are net of expenses.

Besides these differences in the development of the performance between the two continents we also look at the development of the individual groups of mutual funds by country and by investment style as we have done in table 3.7. These results are presented in figure 3.4.

\footnotetext{
${ }^{21}$ We calculated the differences for other horizon lengths as well, but as they didn't influence the results we limit the presentation to the 36 -month period.
} 
The performance in France and in Italy is relatively constant through time and confirms the earlier results. The only remarkable fact in France is the under-performance of the index funds. The most interesting picture is actually provided by the German mutual funds. All classes of funds show a steadily increasing performance relative to their benchmarks. It seems that German fund managers are catching up fast with their European competitors. Whereas in the beginning of the sample period German mutual funds were losing on average $6 \%$ on an annual basis, by the end of the sample period the funds were able to beat the benchmark. In the Netherlands we see a picture that is similar to Germany as the performance improves through time. The U.K. mutual funds behave as expected, as they under-perform the index on average by an amount equal to the fees they charge. When we look at the US funds it seems that only aggressive growth and small cap mutual funds improve their performance. All other styles show a declining average performance.

\subsubsection{Are Funds doing what they are supposed to?}

Our results suggest that there are performance differences between the two continents, between European countries, and between investment styles. In the former section we simply compared the mutual fund return to the market return. However, the performance might also be driven by large cash-positions and/or investments in low beta stocks. Mutual funds hold cash positions for two reasons. First, they need liquidity to be able to respond to investors who sell their shares in mutual funds. Second, the fund managers might want to engage in market timing. To correct for this we use a 2 -factor model, in order to correct for beta risk and holdings in money-market instruments.

$$
R_{i t}-R_{f t}=\alpha_{i}+\beta_{c}\left(R_{m t}-R_{f t}\right)+\beta_{b}\left(R_{b t}-R_{f t}\right)+\varepsilon_{i t}
$$

where $R_{i t}$ represents the logarithmic return of fund $i$ in month $t, R_{f}$ the return on a one month T-bill in month t, $\alpha$ the Jensen (1968) measure for out-performance, $\beta_{\mathrm{c}}$ the exposure to the market index $R_{m t}$ and $\beta_{b}$ the exposure to the bond index $R_{b t}$. We use a standard OLS regression to estimate the coefficients. If $\hat{\beta}_{b}$ is not positive or the corresponding t-statistic is lower than one we estimate (3.1) again without the bond return. As a proxy for the bond return we take the local JP Morgan index and for the money market the local 1-MonthInterbank offer rate.

Table 3.8 presents the results for the whole sample period. Again, we split the sample by country and within a country by investment style. We first analyze the estimation of the equity exposure. As the funds are equity investors we expect them to have an average value of $\hat{\beta}_{e}$ close to one. This means that funds are doing what they are supposed to do: invest in domestic stocks. Germany, the United Kingdom and the United States have an estimated 
average of 0.93 . This means that the domestic equity mutual funds in these countries follow the market closely. In France, Italy and the Netherlands $\hat{\beta}_{e}$ is much lower, which could indicate that the funds also have exposure to other asset markets. For example, we find a high bond exposure in Italy and France ${ }^{22}$. That is, the funds invest relatively a lot of their assets in bonds, despite the fact that they are equity investors. For the Dutch mutual funds it is not clear why the exposures to the local equity market are so low, but one of the explanations could be the dominance of Royal Dutch in the market, which has a limited weight in the AEX index. ${ }^{23}$

To be able to analyze changes in the equity exposure we also calculate the average cross-sectional $\hat{\beta}_{e}$ through time using a rolling window of 36 months. Figure 3.5 presents these results, showing that the United States and the United Kingdom both have estimates close to one and constant through time. All other European countries, including the 'low beta countries', show an increase of the average $\hat{\beta}_{e}$. This indicates that the funds are increasingly following the domestic equity benchmark. It seems that in the beginning of the period the funds were also investing in other assets than domestic stocks.

Besides the possibility to analyze the equity exposure, our model also enables us to evaluate the performance of the funds by the estimation of $\alpha$. These results are presented in table 3.8 as well. In general the results do not differ from the ones presented in paragraphs 3.4.2 en 3.4.3. Again, we find that the average $\hat{\alpha}$ for the European funds is insignificantly different from zero. The United Kingdom and the United States have an annualized $\hat{\alpha}$ of minus $1.04 \%$ and minus $0.65 \%$ respectively. They are the only two countries with a negative performance. Table 3.8 also presents the percentage of funds that have a significant under- or out-performance. Again we see that the United Kingdom and the United States are the worst performers. In these countries $12 \%$ and $14 \%$ of the funds respectively under-perform the benchmark significantly.

\footnotetext{
${ }^{22}$ We have used different local stock indices to test for benchmark sensitivity, but in contrast to Lehman and Modest (1987) this didn't change our findings.

${ }^{23}$ In chapter 5 we will explore the low beta for Dutch funds in more detail. There it is shown that exposures to small cap and value stocks are a possible source.
} 
Table 3.8: Summary Statistics for Performance Measurement

\begin{tabular}{|c|c|c|c|c|c|c|c|c|}
\hline & $\hat{\alpha}$ & $\mathrm{T}(\hat{\alpha})$ & $\hat{\beta}_{e}$ & $\hat{\beta}_{b}$ & $\mathbf{R}^{2}$ & $\mathrm{~N}$ & $\%$ pos / neg & Sign test \\
\hline \multicolumn{9}{|l|}{ France } \\
\hline Growth & 0.33 & 0.14 & 0.72 & 0.04 & 0.85 & 55 & $2.0 / 0.0$ & 0.67 \\
\hline Index & -1.72 & -1.90 & 0.91 & 0.11 & 0.94 & 20 & $0.0 / 3.0$ & -4.47 \\
\hline Smaller companies & 2.37 & 0.65 & 0.70 & 0.16 & 0.80 & 24 & $21.0 / 0.0$ & 2.86 \\
\hline Total & 0.41 & 0.14 & 0.76 & 0.08 & 0.86 & 99 & $6.0 / 6.0$ & -0.10 \\
\hline \multicolumn{9}{|l|}{ Germany } \\
\hline General & 0.29 & 0.14 & 0.90 & 0.00 & 0.92 & 46 & $9.0 / 2.0$ & 0.88 \\
\hline Growth & -1.87 & -0.93 & 0.93 & 0.00 & 0.88 & 5 & $0.0 / 0.0$ & -1.34 \\
\hline Income & -0.71 & -0.21 & 0.95 & 0.00 & 0.94 & 2 & $0.0 / 0.0$ & 0.00 \\
\hline Smaller companies & 5.72 & 1.27 & 1.25 & 0.17 & 0.82 & 4 & $50.0 / 0.0$ & 1.00 \\
\hline Total & 0.45 & 0.11 & 0.93 & 0.01 & 0.91 & 57 & $3.0 / 5.0$ & 0.66 \\
\hline \multicolumn{9}{|l|}{ Italy } \\
\hline Italian equity & 0.58 & 0.21 & 0.58 & 0.13 & 0.83 & 21 & $5.0 / 5.0$ & 1.53 \\
\hline Italian specialist & 0.24 & 0.09 & 0.73 & 0.06 & 0.90 & 16 & $0.0 / 6.0$ & 0.50 \\
\hline Tetal & 0.43 & 0.16 & 0.65 & 0.10 & 0.86 & 37 & $3.0 / 5.0$ & 1.48 \\
\hline \multicolumn{9}{|l|}{ Netherlands } \\
\hline Growth & 1.65 & 1.23 & 0.84 & 0.00 & 0.84 & 5 & $0.0 / 0.0$ & 1.34 \\
\hline Index & -1.03 & -0.70 & 0.95 & 0.00 & 0.88 & 3 & $0.0 / 0.0$ & -1.73 \\
\hline Smaller companies & 2.76 & 0.99 & 0.70 & 0.00 & 0.76 & 1 & $0.0 / 0.0$ & 1.00 \\
\hline Total & 0.88 & 0.46 & 0.79 & 0.00 & 0.84 & 9 & $0.0 / 0.0$ & 0.33 \\
\hline \multicolumn{9}{|c|}{ United Kingdom } \\
\hline Growth/Income & -1.83 & -0.67 & 0.95 & 0.03 & 0.86 & 79 & $1.0 / 5.0$ & -2.59 \\
\hline Income & -1.46 & -0.59 & 0.90 & 0.09 & 0.80 & 72 & $1.0 / 10.0$ & -3.06 \\
\hline Growth & -1.22 & -0.41 & 0.93 & 0.01 & 0.81 & 102 & $2.0 / 18.0$ & -6.14 \\
\hline Smaller companies & 1.15 & 0.29 & 0.95 & 0.00 & 0.79 & 51 & $17.0 / 0.0$ & 2.94 \\
\hline Total & -1.04 & -0.33 & 0.93 & 0.03 & 0.82 & 304 & $4.0 / 12.0$ & -5.16 \\
\hline \multicolumn{9}{|l|}{ United States } \\
\hline Aggressive Growth & -1.69 & -0.41 & 1.04 & 0.43 & 0.72 & 103 & $5.0 / 5.0$ & -3.05 \\
\hline Growth & -1.58 & -0.36 & 0.94 & 0.01 & 0.70 & 937 & $2.0 / 16.0$ & -8.13 \\
\hline Income & 0.70 & 0.31 & 0.72 & 0.10 & 0.82 & 144 & $3.0 / 6.0$ & 1.50 \\
\hline Growth/ncome & -0.38 & -0.12 & 0.88 & 0.02 & 0.86 & 499 & $4.0 / 22.0$ & -5.03 \\
\hline Smaller companies & 0.83 & 0.14 & 1.02 & 0.08 & 0.81 & 413 & $29.0 / 2.0$ & 9.42 \\
\hline Total & -0.65 & -0.15 & 0.93 & 0.05 & 0.77 & 2096 & $8.0 / 14.0$ & -1.97 \\
\hline
\end{tabular}

Notes: This table presents the results of the estimation of equation (3.1) by country and investment style using monthly data for the period between 1991 and 1997. Formally:

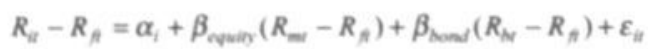

The first column gives the average value of $\alpha$, which is presented in annualized percentage terms. The second column gives the corresponding t-statistic. The third and fourth give the average of the estimated values for the two $\beta$ 's. The fifth column gives the adjusted $R^{2}$, and the sixth column the number of funds. The sixth column gives the percentages of significant $\alpha$ 's, divided into positive and negative and the last columns gives the test statistic of a binominal sign test indicating the significance of the number of positive and negative $\alpha$ 's. 
Figure 3.5: Average Equity beta's for Individual Countries Through Time

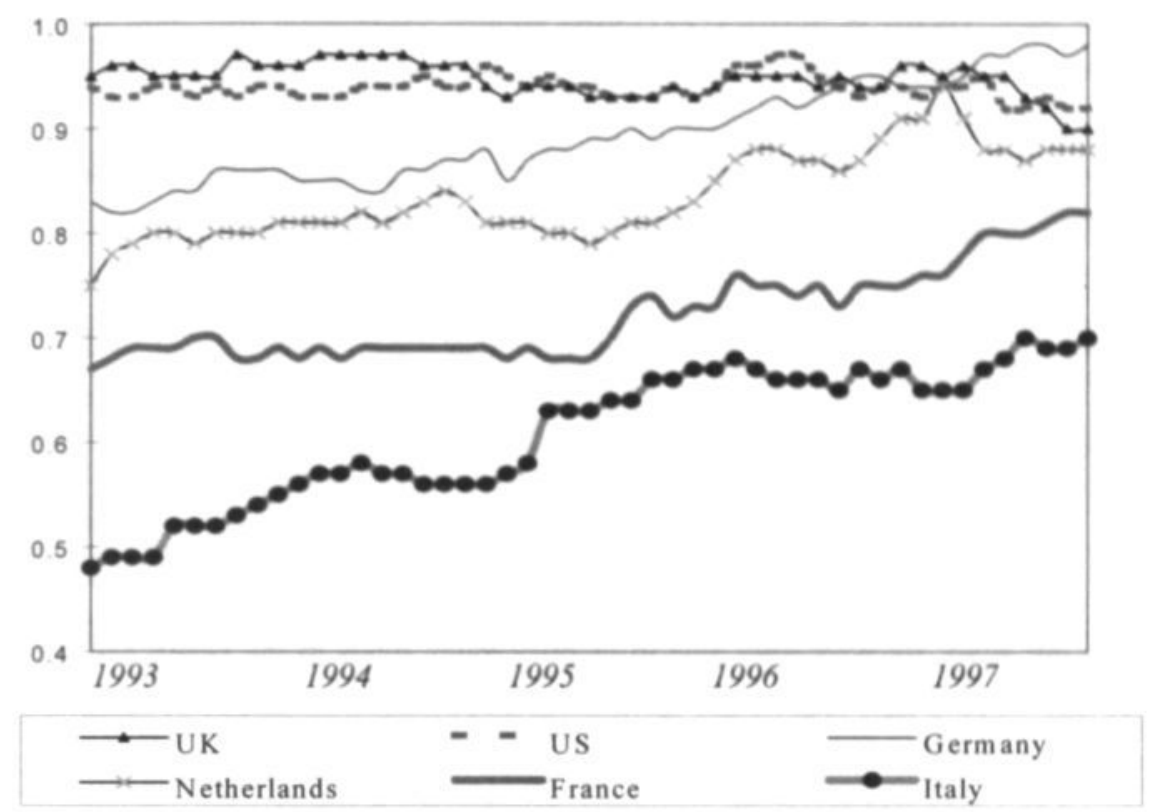

Notes: In this figure average $\hat{\beta}_{e}$ 's are plotted through time, by using a 36-month moving window. Period is 1991-1997.

\subsubsection{The Influence of Fees on Performance}

In tables 3.7 and 3.8 we show that the U.K. and US mutual funds under-performed their relevant benchmarks. We expect to find this under-performance in mature and efficient markets. The under-performance can be completely explained by the costs funds charge. When we add back expenses to all the funds the $\hat{\alpha}$ 's range from $0.1 \%$ for the United Kingdom to $2.5 \%$ for Italy. This means that the negative $\hat{\alpha}$ 's we found for the United Kingdom and the United States become positive. This is in line with the general findings in the literature. Table 3.7 presents the average cost figures for each individual mutual fund class. The average fee varies between $0.5 \%$ for the Netherlands and $2.0 \%$ for Italy. Especially the fee paid for the French index funds is high with an average of $1.2 \%$, where Gruber (1996) reports average fees for US index funds equal to $0.23 \%$.

Chordia (1996) and Tufano and Sevick (1997) have studied mutual fund fees. We see that especially in the United States fees are high and above all are growing each year. The fee of the average equity mutual fund (including international funds) is equal to $1.6 \%$ in 1997 , 
whereas in 1992 the average fee was only $1.4 \%$. It is remarkable that fees are rising while we would expect them to fall because of economies of scale and increased competition. A possible explanation is the proliferation of new funds that tend to have higher expense ratios than older ones. Tufano \& Sevick (1997) offer another explanation why fund fees are high. They report that a higher number of directors on a board leads to higher salaries and quicker approval of higher fees.

\subsubsection{The Under-Performance of European Index Funds}

The purpose of an index fund is to follow a particular index. From several studies (see for example Gruber (1996)) we know that activism doesn't pay and that the existence of index funds is beneficial for the investor. Gruber (1996) showed that, during the period 1990-1994, a sample of $100 \mathrm{~S} \& \mathrm{P} 500$ index-funds had $\beta$ 's of 1 and $\alpha$ 's close to zero where actively managed US funds had an average alpha of $-1.6 \%$ a year. Even after adding back expenses, the difference between index funds and actively managed funds remained.

In our study we were only able to identify index funds in the Dutch and the French sample. The three Dutch index funds gave a lower performance than we expected with an average $\hat{\alpha}$ of -1.03 , a $\hat{\beta}_{e}$ of 0.95 , and an $\mathrm{R}^{2}$ of $88 \%$. The performance of the French mutual funds is also remarkable with a $\hat{\beta}_{e}$ of 0.91 , and a corresponding $\hat{\alpha}$ of -1.72 . Furthermore, the expenses charged by the French funds are at $1.2 \%$ exceptionally high for these kinds of funds. Even after we add back these expenses the performance remains negative for both countries.

\subsubsection{The Out-Performance of Small Cap Mutual Funds}

In this paragraph we discuss the remarkable result of the mutual funds that focus on smaller companies. In general these mutual funds out-performed their benchmark during the sample period. If we return to table 3.7 , we see that in 3 out of 5 countries the return of the fund is higher than the appropriate small cap benchmark. We also see that the average return from these funds is higher than the averages from all other investment styles except for the German small cap funds. This is even more remarkable when we see that in all European countries (except for the Netherlands) the general equity index out-performs the small cap index. The observed out-performance is confirmed in table 3.8 where we present the results for the attribution analysis. The table shows that small company mutual funds have a positive $\hat{\alpha}$ in each country when we include the money and bond market in the regression. The percentage of small cap mutual funds out-performing the market is high, $27 \%$ of all funds have positive $\hat{\alpha}$ 's significantly different from zero. This finding is confirmed by the sign test. Therefore, 
this suggests that selection and timing abilities do play a role in this field. This might be due to the lower level of market efficiency in these less researched small cap markets.

\subsection{Conclusions}

In this chapter we take a close look at the European mutual fund industry and compare it with the United States using a traditional structure-conduct-performance paradigm. We find that Europe is still lagging the US mutual fund industry when it comes to total asset size, average fund size, and market importance. Furthermore, it appears that European citizens have a preference for fixed income mutual funds, whereas the American prefers mutual funds investing in equity. Besides these findings we show that the mutual fund markets in the individual European countries are dominated by a few large domestic fund groups, which could possibly lead to lower levels of competition.

In our performance tests we observe five interesting findings. First, the European mutual funds have on average a better performance than their American counterparts. This is remarkable as we conclude from the earlier analysis that levels of competition might be lower in Europe. Theoretically we would assume the opposite. Second, we find a dramatic increase in the performance of the German mutual fund sector. Third, we show that the Italian, French, and Dutch mutual funds have a low exposure to their domestic equity benchmark. This exposure however, is rising through time, which indicates that they are increasingly behaving as we expect them to do. Fourth, the results suggest that European index funds are not following pure index strategies. Finally, small cap mutual funds in both Europe and the United States out-perform the benchmark and all other mutual funds. In this market segment mutual funds apparently add more value than their counterparts in the large cap segment.

The performance results indicated in this chapter should however be treated with care. From chapter 2 we know about the existence of a whole range of more elaborate performance models, in contrast to the relative simple 2-factor model used in this chapter. In the next chapter we therefore provide an empirical exploration of all existing mutual fund performance models. For this we use the recently released survivorship-bias free US mutual fund database by CRSP. The richness of this database, 40 years of data on thousands of funds, enables us to investigate model specifications in much more detail. The results of that chapter will then be used to measure European fund performance throughout the remainder of the thesis. 



\section{Chapter 4}

\section{Mutual Fund Performance Models ${ }^{24}$}

\subsection{Introduction}

The value of active management has been a source of debate for decades. The majority of US studies conclude that actively managed portfolios, on average, under-perform market indices. For example Jensen (1968) and Sharpe (1966) argue mutual funds under-perform the market by the amount of expenses they charge the investor. A study by Ippolito (1989) however documented significantly positive performance of US mutual funds, when compared to the S\&P 500 index. The Ippolito article marked the renewed interest in mutual fund performance measurement. Subsequent authors argued Ippolito's results were mainly driven by non-S\&P 500 holdings in mutual fund portfolios. This led to the emergence of extended models that control for several stock market anomalies. For instance Fama \& French $(1993,1996)$ add proxies for size and book-to-market, while Carhart (1997) introduces a stock-momentum variable. Finally Ferson \& Schadt (1996) explore the added value of introducing time-varying betas and alphas in existing models. Hereby acknowledging the fact that fund managers change their portfolios over time, based on observable information variables.

Most of these papers however only deal with one, or at most two different performance models. Because of the relative large number of mutual fund performance models this potentially creates a problem for both academics and practitioners, what model to use for performance measurement? The purpose of this chapter is to provide a comprehensive assessment of existing mutual fund performance models, using a survivor-bias free database of all US mutual funds. Starting with the most basic single factor CAPM model, we then

\footnotetext{
${ }^{24}$ This chapter is based on R. Otten and D. Bams, 'Mutual Fund Performance Models', LIFE Working Paper, 2002
} 
explore the added value of introducing extra variables like size, book-to-market, momentum and a bond index. In addition to that we evaluate the use of introducing time-variation in betas and alpha.

The search for the most suitable model to measure mutual fund performance will be addressed along two lines. First, we are interested in the statistical significance of adding more factors to the single factor model. Second, we focus on the economic importance of more elaborate model specifications. The added value of this study lies both in the step-wise process of identifying relevant factors, and the use of a rich US mutual fund database that was recently released by the Center for Research in Security Prices (CRSP). Throughout the remainder of this thesis we will build upon the results from using this US database. Where applicable, we will use similar model specifications to measure European mutual fund performance.

The remainder of this chapter is organized as follows. In section 4.2 we provide a discussion on mutual fund performance models. Section 4.3 describes the data. Our empirical results are presented in section 4.4 and section 4.5 concludes this chapter.

\subsection{Mutual Fund Performance Models}

\subsubsection{Unconditional Models}

The first models used to evaluate risk-adjusted fund performance were based on the work by Sharpe, Lintner, Treynor and Mossin on the Capital Asset Pricing Model (CAPM). For instance, Jensen (1968) suggested to employ the following model based on the CAPM.

$$
R_{i t}-R_{f t}=\alpha_{i}+\beta_{i}\left(R_{m t}-R_{f t}\right)+\varepsilon_{i t}
$$

where $R_{i t}$ is the return on fund $i$ in month $t, R_{f}$ the return on a one month T-bill in month $t$, $R_{m t}$ the return on the local equity benchmark in month $t$ and $\varepsilon_{i t}$ an error term. The intercept of this model, $\alpha_{i}$, gives the Jensen alpha, which is usually interpreted as a measure of out- or under-performance relative to the used market proxy.

Such a single factor model however assumes that a fund's investment behavior can be approximated using only a single market index, for instance the S\&P 500 for the United States. It does however not account for non-S\&P 500 holdings, like for instance small cap stocks. For this reason Elton, Gruber, Das \& Hlavka (1993) propose to add a small cap benchmark to the previous 1-factor CAPM model. In addition to that, Fama \& French (1992, 1993, 1996) provide strong evidence for the relevance of yet another factor, besides a small cap index. Based on their work on the cross-sectional variation of stock returns, Fama \& French (1993) propose a 3-factor model. Besides a value-weighted market proxy two additional risk factors are used, size and book-to-market. The Fama French (FF) model reads: 


$$
R_{i r}-R f_{t}=\alpha_{i}+\beta_{0 i}\left(R m_{t}-R f_{i}\right)+\beta_{1 i} S M B_{1}+\beta_{2 i} H M L_{1}+\varepsilon_{i t}
$$

where

$$
\begin{aligned}
& \mathrm{SMB}_{t} \quad=\quad \text { the difference in return between a small cap portfolio and a } \\
& \text { large cap portfolio at time } \mathrm{t} \\
& \mathrm{HML}_{\mathrm{t}} \quad=\text { the difference in return between a portfolio of high } \\
& \text { book-to-market stocks and a portfolio of low book-to-market } \\
& \text { stocks at time t }
\end{aligned}
$$

Although this model improves average CAPM pricing errors, it is not able to explain the cross-sectional variation in momentum-sorted portfolio returns. Therefore Carhart (1997) extends the Fama-French model by adding a fourth factor that captures the Jegadeesh \& Titman (1993) momentum anomaly. The resulting model is consistent with a market equilibrium model with four risk factors, which can also be interpreted as a performance attribution model, where the coefficients and premia on the factor-mimicking portfolios indicate the proportion of mean return attributable to four elementary strategies.

The Carhart model reads:

$$
R_{i t}-R f_{t}=\alpha_{i}+\beta_{0 i}\left(R m_{t}-R f_{t}\right)+\beta_{1 i} S M B_{t}+\beta_{2 i} H M L_{t}+\beta_{3 i} P R I Y R_{t}+\varepsilon_{i t}
$$

where

$$
\begin{aligned}
& \text { PRIYR }=\quad \text { the difference in return between a portfolio of past winners and } \\
& \text { a portfolio of past losers at time } t
\end{aligned}
$$

Finally, Elton, Gruber, Das \& Hlavka (1993) and Elton, Gruber \& Blake (1999) propose the inclusion of a bond index in mutual fund performance assessment. They argue that some funds invest in higher yielding and risky bonds, which is not picked up by the risk-free rate (Rf). Although in their analysis the bond index only shows up significantly for less than $50 \%$ of all funds, we consider the sensitivity of funds returns to a Government bond index.

$$
R_{i t}-R f_{t}=\alpha_{i}+\beta_{0 i}\left(R m_{t}-R f_{t}\right)+\beta_{1 i} S M B_{t}+\beta_{2 i} H M L_{1}+\beta_{3 i} P R I Y R_{t}+\beta_{4 i}\left(R b_{t}-R f_{t}\right)+\varepsilon_{i t}(4.4)
$$

where

$$
\mathrm{Rb}_{\mathrm{t}}=\text { the return on a government bond index at time } \mathrm{t}
$$




\subsubsection{Conditional Models}

Traditionally performance is measured using unconditional expected returns, assuming that both the investor and manager use no information about the state of the economy to form expectations. If managers however trade on publicly available information, and employ dynamic strategies, unconditional models may produce inferior results. Calculating average alphas using a fixed beta estimate for the entire performance period consequently leads to unreliable results if expected returns and risks vary over time. To address these concerns on unconditional performance models, Chen \& Knez (1996) and Ferson \& Schadt (1996) advocate conditional performance measurement.

This is done by using time-varying conditional expected returns and conditional betas instead of the usual, unconditional betas. To illustrate this, consider the following case were $\mathbf{Z}_{n-1}$ is a vector of lagged pre-determined instruments. Assuming that the beta for a fund varies over time, and that this variation can be captured by a linear relation to the conditional instruments, then $\beta_{i t}=\beta_{i 0}+\mathbf{B}_{i}^{\prime} \mathbf{Z}_{1-1}$, where $\mathbf{B}_{i}^{\prime}$ is a vector of response coefficients of the conditional beta with respect to the instruments in $\mathbf{Z}_{n-1}$. For a single index model the equation to be estimated reads:

$$
R_{i t}-R f_{t}=\alpha_{i}+\beta_{i 0}\left(R m_{t}-R f_{t}\right)+B_{i}^{\prime} Z_{i-1}\left(R m_{t}-R f_{t}\right)+\varepsilon_{i t}
$$

This equation can easily be extended to incorporate multiple factors, which results in a conditional model with time-varying betas. The instruments we use are publicly available and proven to be useful for predicting stock returns by several previous studies. ${ }^{25}$ Introduced are (1) the 1-month T-bill rate, (2) dividend yield on the market index, (3) the slope of the term structure and finally (4) the quality spread, by comparing the yield on government and corporate bonds. All instruments are lagged 1 month.

In this chapter we evaluate the added value for performance measurement, of introducing time-variation in several betas. First, we let the CAPM market beta vary over time. Subsequently time-variation is added to SMB and HML (FF), Momentum (Carhart) and the bond beta.

Finally Christopherson, Ferson \& Glassman (1998) and Christopherson, Ferson \& Turner (1999) argue that in the same way beta can be dynamic, alphas may also be dynamic. All prior models assume abnormal performance to be constant over time. Introducing timevariation in alpha makes it possible to examine whether managerial performance is indeed constant, or whether it varies over time as a function of the conditioning information. Our

\footnotetext{
${ }^{25}$ Pesaran and Timmerman (1995) discuss several studies that emphasize the predictability of returns based on interest rates and dividend yields.
} 
final model therefore introduces time-variation in alpha, in order to explore the added value for performance measurement.

Formally we test 9 model specifications, which will be evaluated based on statistical and economic relevance. These models include:

Model

1) Unconditional CAPM

2) Unconditional Fama \& French

3) Unconditional Fama \& French + Momentum

4) Unconditional Fama \& French + Momentum + Bond

5) Conditional CAPM

6) Conditional Fama \& French

7) Conditional Fama \& French + Momentum

8) Conditional Fama \& French + Momentum + Bond

9) Conditional Fama \& French + Momentum + Bond + Alpha

\section{Number of factors}

\section{1}

3

4

5

5

15

20

25

30

\subsection{Data}

\subsubsection{The CRSP Survivor-bias Free US Mutual Fund Database}

To examine the efficiency of existing mutual fund performance models, we employ the richest commercial database available at this moment. Originally created by Mark Carhart in 1993, the CRSP Survivor-bias Free US Mutual Fund database currently serves as the main database for academic research on fund performance and behavior. ${ }^{26}$ The database covers all US mutual funds during the $1962-2000$ period. Besides fund returns, it provides a vast range of retrievable fund specific variables. For instance, expense ratio, net-asset value (NAV), flows, turnover, investment style, portfolio holdings and manager information.

The main advantage of this particular database however, derives from the fact that also dead funds are included. Several authors documented an overestimation of average returns if only funds that survived throughout the entire sample period were included. ${ }^{27}$ This derives from the fact that funds with bad performance are frequently being shut down or merged into another one. This "kills" bad track records and gives an overestimation of the average performance if only surviving funds are evaluated. In contrast to popular databases like for instance Morningstar and Lipper, the CRSP database also provides information on these nonsurviving funds. This enables us to assess survivorship bias in measuring mutual fund returns.

\footnotetext{
${ }^{26}$ See for example Carhart (1997 and 2000) and Khorana \& Servaes (1999)

${ }^{27}$ See Brown, Goetzmann, Ibbotson \& Ross (1992), Malkiel (1995), Gruber (1996) and Carhart et al (2000)
} 


\subsubsection{Mutual Fund Data}

Using CRSP we construct a database of all domestic US equity funds with at least 24 months of data. That is, we exclude balanced and guaranteed funds and equity funds that invest internationally. This leads to a sample of 2436 open-ended equity mutual funds with monthly logarithmic returns from January 1962 through December 2000. All returns are in USD, inclusive of distributions and net of management fees. To investigate the influence of investment style on performance we divide funds into sub-groups, using self-reported investment styles. This leads to 6 portfolios of funds, aggressive growth/small cap, growth, growth/income, income, all funds and a portfolio of surviving funds only. ${ }^{28}$ Summary statistics on these portfolios are presented in table 4.1, panel A. This table provides a first indication of a possible survivorship-bias. Only including funds that survived through December 2000 , would eliminate 288 dead funds, $12 \%$ of the database. This would lead to a significant overestimation of average fund returns of $0.51 \%$ on a yearly basis. ${ }^{29}$ Therefore it looks like excluding dead funds indeed has a severe impact on mutual fund performance measurement.

\subsubsection{Benchmark Indices and Predetermined Information Variables}

To determine the explanatory power of a range of performance models, discussed in the previous paragraph, we use the following benchmarks. From Eugene Fama we obtain returns on the aggregate US market index and the factor mimicking portfolios for size (SMB) and book-to-market (HML). The factor-mimicking portfolio for the one-year momentum in stock returns (PRIYR) is provided by Mark Carhart. In addition to that we include the Lehman Brothers Aggregate Government Bond index to test for cash holdings. Finally we examine the marginal explanatory power of introducing time-variation in betas and alpha. In line with for instance Ferson \& Schadt (1997), we use a collection of public information variables that prove to be able to predict returns and risks over time. Introduced are (1) the 1-month T-bill rate, (2) dividend yield on the market index, (3) the slope of the term structure and finally (4) the quality spread, by comparing the yield of government and corporate bonds. All instruments are lagged 1 month to be predictive. Panel B and C of table 4.1 present summary statistics on benchmark returns and informational variables.

\footnotetext{
${ }^{28}$ As CRSP does not make a clear distinction between aggressive growth and small cap funds we group them into one portfolio. Tests on individual fund results confirm our belief that these funds invest quite similarly.

${ }^{20}$ The corresponding t-stat for a test for equal means is 2.53 .
} 
Table 4.1: Summary Statistics, 1962:01 - 2000:12

Panel A: Mutual Fund Returns

\begin{tabular}{lrrr}
\hline Investment objective & $\begin{array}{c}\text { Mean } \\
\text { Return }\end{array}$ & $\begin{array}{c}\text { Standard } \\
\text { Deviation }\end{array}$ & $\begin{array}{r}\text { Number } \\
\text { of Funds }\end{array}$ \\
\hline Aggressive Growth / Small Companies & 12.51 & 20.05 & 793 \\
Growth & 11.56 & 15.46 & 985 \\
Growth/Income & 10.95 & 14.39 & 519 \\
Income & 12.01 & 12.53 & 139 \\
\hline All funds & 11.66 & 16.12 & 2436 \\
\hline Surviving funds only & 12.17 & 15.99 & 2148 \\
\hline
\end{tabular}

Panel B: Benchmark returns

\begin{tabular}{|c|c|c|c|c|c|c|c|}
\hline \multirow[b]{2}{*}{ Benchmark } & \multirow[b]{2}{*}{$\begin{array}{l}\text { Mean } \\
\text { Return }\end{array}$} & \multirow[b]{2}{*}{$\begin{array}{l}\text { Standard } \\
\text { Deviation }\end{array}$} & \multirow[b]{2}{*}{$\begin{array}{l}\text { t-stat } \\
\text { for } \\
\text { mean = } 0\end{array}$} & \multicolumn{4}{|c|}{ Cross-Correlations } \\
\hline & & & & RM & SMB & HML & PRIYR \\
\hline Market (RM) & 11.87 & 15.33 & 4.83 & 1.00 & & & \\
\hline SMB & 1.63 & 11.16 & 0.91 & 0.30 & 1.00 & & \\
\hline HML & 5.19 & 9.95 & 3.25 & -0.40 & -0.27 & 1.00 & \\
\hline PR1YR & 12.41 & 13.82 & 5.60 & -0.01 & -0.14 & -0.09 & 1.00 \\
\hline Government Bond & 7.55 & 8.42 & 5.38 & 0.26 & -0.06 & 0.02 & 0.09 \\
\hline
\end{tabular}

Panel C: Instrumental Variables

\begin{tabular}{l} 
Mean $\begin{array}{l}\text { Standard } \\
\text { Variable }\end{array}$ \\
\cline { 4 - 6 }
\end{tabular}




\subsection{Empirical Results}

\subsubsection{All Funds Portfolio}

To examine the statistical and economic power of a range of mutual fund performance models we first focus on the results at an aggregated level. That is, we use an equally weighted portfolio of all funds as input. In paragraph 4.4.3 we group funds into portfolios based on selfreported investment styles. This enables us to examine the explanatory power of several models in more detail.

Table 4.2 presents our findings with respect to the 'all funds portfolio'. For each of the 9 models we report, alpha, beta(s), $\mathrm{R}^{2}$ adj and loglikelihood $(\log L)$. Using the $\log L$ we perform a standard Likelihood ratio (LR) test in order to determine whether the explanatory power of the new model differs significantly from a previous one in a statistical sense. These comparisons are performed on two different levels. First, we compare all models to the previous model (see column 10 in table 4.2). For instance, whether the FF 3-factor model fits better than the 1-factor CAPM and subsequently whether the Carhart 4-factor model fits better compared to the FF 3-factor model. Second, we examine whether the conditional version fits better than the unconditional version (see last column in table 4.2). Again, for instance we compare the conditional CAPM model to the unconditional CAPM. If two times the difference in $\log L$ between two models exceeds the corresponding critical value of a $\chi_{\text {sv }}^{2}$ (df) test statistic we report a "Yes". If not, a "No" is reported, indicating that the new model does not significantly add explanatory power in assessing mutual fund performance.

Besides the LR test for testing statistical power we also consider the economic power of adding more variables to the model. By looking at the change in risk-adjusted return, alpha, we try to assess whether more elaborate models lead to an economically significant improvement. For instance if a richer model specification would lead to a significant increase in $\log L$ but no change in alpha, we would consider the extra economic relevance of this model to be insufficient.

We start our testing sequence by introducing the CRSP total market index in a single factor unconditional CAPM model (1). Using a single factor model leads to a yearly alpha estimate of -0.45 , a market beta of 1.02 and an $R_{\text {adj }}^{2}$ of 0.94 . Based on these results we could argue that mutual funds follow the market quite closely, but under-perform the index by $0.45 \%$ per year. This under-performance however is not significant. The next model we consider is the FF 3-factor model, which introduces two additional risk factors, size and bookto-market (2). The inclusion of two extra factors leads to a significant increase in $\log L$, indicating the relevance of the FF model versus the CAPM. Examining the betas enables us to comment on the funds' average investment strategies. As the SMB factor loading is significantly positive we believe the all funds portfolio is relatively more driven by small cap 
returns than by large cap returns. The HML factor loading on the other hand is significantly negative, indicating a sensitivity to low book-to-market stocks (growth) instead of high bookto-market stocks (value). Furthermore the exposure to the market beta drops to 0.96 , after adding SMB and HML. Controlling for the lower market risk, size and book-to-market exposures, the alpha estimate rises from -0.45 to 0.04 .

Model (3) emerges after adding the momentum factor PRIYR, resulting in the Carhart model. The significantly positive PRIYR coefficient signals the sensitivity of the all funds portfolio for high momentum stocks. Based on the increase in $\log L$, the 4-factor Carhart model is better in explaining mutual fund returns. The inclusion of the momentum factor finally makes the alpha estimate decrease to -0.51 . The last unconditional model (4) considers the additional value of a government bond index. Although the $\log L$ of this model increases compared to the previous model, it does not meet the critical value at the $5 \%$ level. Furthermore the bond beta is negative, which would imply the overall fund is borrowing bonds. From a statistical viewpoint we therefore conclude that in an unconditional setting the 4-factor Carhart model (3) is best suitable to measure mutual fund performance.

Starting with model (5) we move over to conditional performance measurement. This model introduces time-variation in the CAPM beta. Judging from the increase in loglikelihood (last column of table 2), introducing time-variation in market beta clearly adds explanatory power, compared to the unconditional CAPM model. Note that for the conditional models we do not report OLS estimates for betas (model 5-9) and alpha (model 9) in subsequent tables. We rather focus on the variation through time of specific variables. These results are given in figure 4.1, which will be discussed after dealing with the most extensive model (9).

After adding time-variation to the market beta (model 5) we now allow the SMB and HML to vary as well (model 6). This not only leads to a significant increase in loglikelihood compared to the unconditional model, but as well to the previous conditional CAPM model. The alpha from this model now becomes positive. Thus, not taking into account timevariation, led to an under-estimation of managerial performance. Along the same lines we introduce time-variation in momentum (model 7), bond (model 8) and finally alpha (model 9). Based on the increase in loglikelihood we observe a significant improvement for both model (7) and (8), compared to the previous conditional models with less factors. Only the introduction of time-variation in alpha does not lead to an increase in explanatory power. Finally all conditional models perform much better than their unconditional peers (see last column of table 4.2). 


\begin{tabular}{|c|c|c|c|c|c|c|c|c|c|c|}
\hline Model & Alpha & Market & SMB & HML & PRIYR & Bond & $\mathbf{R}^{2}$ all & $\log L$ & $\begin{array}{r}\text { Significant } \\
\text { increase in } \log L \\
\text { to previous } \\
\text { model? }\end{array}$ & $\begin{array}{r}\text { Significant } \\
\text { increase in } \log L \\
\text { to unconditional } \\
\text { model? }\end{array}$ \\
\hline (1) Unconditional CAPM & -0.45 & $1.02^{\circ .0}$ & & & & & 0.94 & 1947.60 & & \\
\hline (2) Unconditional FF & 0.04 & $0.96 \ldots$ & $0.22^{\cdots}$ & $-0.06^{\cdots}$ & & & 0.96 & 2054.65 & Yes & \\
\hline (3) Unconditional FF + Momentum & -0.51 & $0.96^{\cdots}$ & $0.23^{\cdots}$ & $-0.05^{\cdots}$ & $0.03^{\cdots}$ & & 0.96 & 2058.59 & Yes & \\
\hline (4) Unconditional FF + Momentum + Bond & -0.54 & $0.96^{\cdots \cdots}$ & $0.23^{\cdots}$ & $-0.05^{\cdots}$ & $0.03^{\cdots}$ & $-0.04^{*}$ & 0.96 & 2060.43 & No & \\
\hline (5) Conditional CAPM & -0.38 & & & & & & 0.94 & 1952.49 & & Yes \\
\hline (6) Conditional FF & 0.17 & & & & & & 0.97 & 2104.73 & Yes & Yes \\
\hline (7) Conditional FF + Momentum & -0.42 & & & & & & 0.97 & 2121.53 & Yes & Yes \\
\hline (8) Conditional FF + Momentum + Bond & -0.46 & & & & & & 0.97 & 2129.08 & Yes & Yes \\
\hline $\begin{array}{l}\text { (9) Conditional FF + Momentum + Bond + } \\
\text { Conditional Alpha }\end{array}$ & & & & & & & 0.97 & 2129.90 & No & \\
\hline \multicolumn{11}{|c|}{$\begin{array}{l}\text { Notes: Table } 4.2 \text { reports OL.S estimates for the } 9 \text { different models we employ. As input we use an equally weighted portfolio of all mutual funds in our sample. For each } \\
\text { model we provide an annualized alpha, betas, } R_{\text {sdj }} \text { and loglikelihood. The last two columns provide an answer to the question whether the explanatory of the new model differs } \\
\text { significantly from the previous model (column } 10 \text { ) and whether it differs from the corresponding unconditional model (column } 11 \text { ). If } 2 \text { times the difference in Log } L \text { between } \\
\text { two models exceeds the corresponding critical value of a } \chi^{2} s \mathrm{~s} \text { (df) we report a "Yes". If not, a "No" is reported, indicating that the new model does not significantly add } \\
\text { explanatory value in assessing mutual fund performance. } \\
\text { significant at the } 1 \% \text { level. } \\
\text { significant at the } 5 \% \text { level. } \\
\text { significant at the } 10 \% \text { level }\end{array}$} \\
\hline
\end{tabular}


We now elaborate upon the time-varying nature of the alpha and betas discussed before. In figure 4.1 we provide the time-varying parameters with accompanying $95 \%$ confidence bounds. These pictures enable us to extract some interesting conclusions. First of all the alpha of the all funds portfolio seems to exhibit only weak time-variation, as the average estimate moves around $-0.5 \%$ quite closely. This confirms the insignificant increase in explanatory power of the conditional alpha model (9) compared to the previous model (8). Note also that at no point the alpha is significantly different from zero, based on the $95 \%$ confidence bounds. This implies that after controlling for a series of relevant risk factors, and in addition to that, time-variation in alpha and betas, the average mutual fund manager does not beat the market.

In contrast to the weak time-variation of mutual fund alpha, figure 4.1 presents a clear indication of the time-varying nature of the market beta, SMB, HML, PRIYR and the bond beta through time. For instance during the last decade the average fund increased its exposure to the market index (market), decreased the small cap overweight (SMB) and moved from a growth bias to a significant value exposure (HML). Conditional models therefore deliver important information with regard to the dynamic investment behavior of mutual fund managers.

\subsubsection{Survivors}

Like mentioned before, leaving out dead funds leads to an overestimation of fund returns. Based on raw returns the portfolio consisting of surviving funds significantly out-performs the portfolio of all funds by $0.51 \%$ per year. To examine the influence of survivorship-bias on risk-adjusted alphas we re-estimate all model specifications using the surviving funds portfolio. These results are reported in table 4.3.

The first observation we can derive from table 4.3 is the higher alpha for all models compared to table 4.2. Using the survivor portfolio, alphas are overestimated in the range between $0.28 \%$ (model 1 ) and $0.64 \%$ (model 5). Our conclusions with respect to mutual fund investment styles and explanatory power of the different models however remain unchanged. Firstly, beta estimates for the market, SMB, HML, PR1YR and Bond are almost identical. Secondly, adding SMB, HML and PRIYR significantly improves the unconditional model, while the bond variable does not. Thirdly, introducing time-variation in betas leads to a significantly better model, while finally alpha is not time-varying. Although excluding dead funds is not likely to influence the statistical power of our performance models it does overestimate managerial risk-adjusted performance. Therefore throughout the remainder of this chapter we will use all US mutual funds available, including dead funds. 
Figure 4.1: Time-varying alpha and betas for the all funds portfolio, 1962:01-2000:12

A.PHA

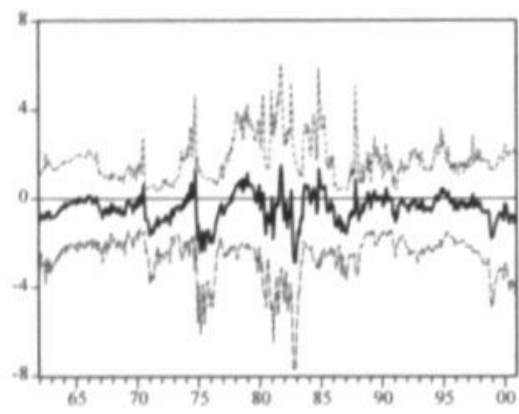

SMB

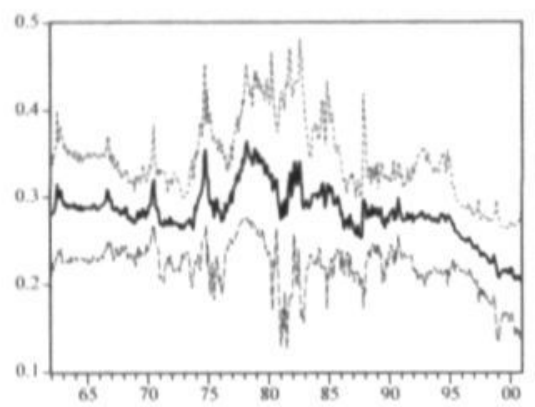

PRIVR

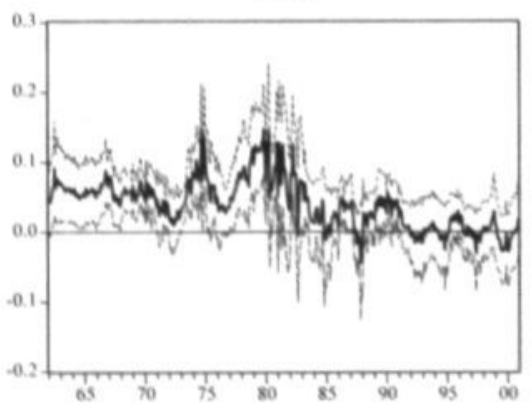

Market

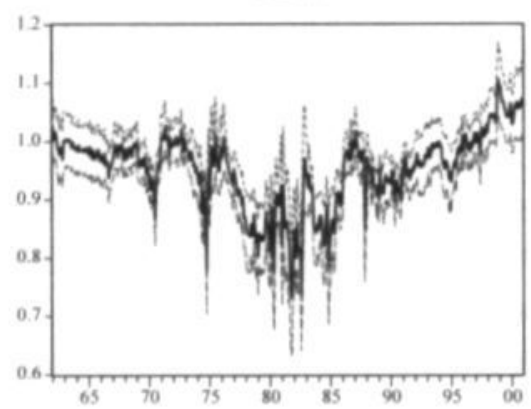

HML.

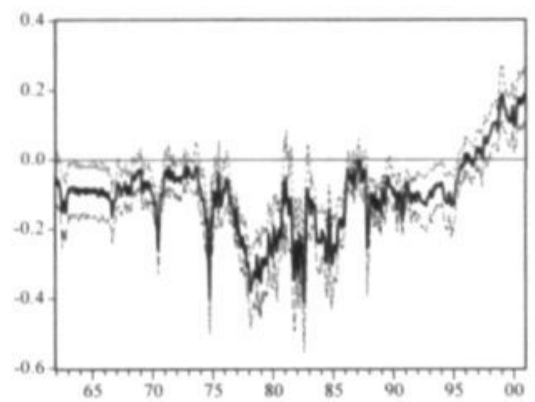

Bond

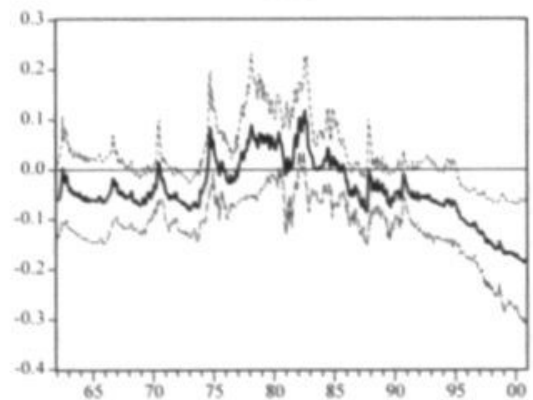

Notes: This figure presents the time-varying alpha, market beta, SMB, HML, PRIYR and Bond for the all funds portfolio. In order to introduce time-variation we allow the alpha, market beta, SMB, HML, PRIYR and Bond to vary over time as a function of (1) the 1 month T-bill rate, (2) dividend yield (3) the slope of the term structure and (4) the quality spread. Given are the time-varying parameter estimates (solid line), while $95 \%$ confidence bounds are indicated using dashed lines. 


\subsubsection{Investment Style Level}

Now we examine whether the previous results are biased because we pool all funds within one portfolio. Therefore we investigate the explanatory power of our 9 performance models at the investment style level. Based on self-reported investment styles we have built 4 equally weighted portfolios of funds. This allows us to dig deeper into the drivers of mutual fund returns, which in turn leads to a more detailed analysis of fund performance. The results for each individual investment style are reported in table 4.4 . For brevity reasons we will not discuss every portfolio in detail, but rather try to assess the overall results.

In line with prior results indicated in tables 4.2 and 4.3 , the inclusion of the SMB and HML variables (model 2) adds explanatory power to the unconditional models for all four style portfolios. The PRIYR momentum factor (model 3) shows up significant in 3 out of 4 portfolios, only the growth/income portfolio seems not be significantly exposed to stock price momentum. While the bond index (model 4 ) did not improve explanatory model based on the all funds portfolio, it does add value for the growth funds portfolio. The remaining 3 portfolios however are not significantly exposed to a government bond index.

Moving over to conditional performance models we first have to note the statistical superiority of all conditional models over their unconditional counterparts, based on the significant increase in $\log L$. Within the range of conditional models, the addition of a timevarying SMB, HML and PR1YR momentum factor is again relevant for all style portfolios (model 5 to 7 ). The evidence for the bond index is mixed. While for both the growth and income portfolio model (8) significantly increases loglikelihoods, for the aggressive growth/small cap and the growth/income portfolio it does not. Significant time-variation in alpha can finally only be documented for the income portfolio.

To illustrate the time-variation in alpha and betas for the income portfolio we refer to figure 4.2. First, the figure presents visual evidence for time-variation in alpha. Alphas range from $+10 \%$ to $-7 \%$ over the $1960-2000$ period. During the last 5 years the income portfolio even under-performs the market significantly by over $5 \%$ per year. Second, we find distinct patterns in the market beta (increasing), HML (increasing) and bond (decreasing) over time.

The economic relevance of the 9 different model specifications will again be illustrated by examining the influence of more elaborate performance models on alpha. For the aggressive growth/small cap and growth portfolio the alpha estimates do not change dramatically when going from an unconditional CAPM model (1) to for instance a conditional Carhart model (7). For the growth/income and income portfolio the use of more elaborate performance models has quite a large impact on mutual fund alphas. Moving from an unconditional CAPM model (1) to for instance a conditional Carhart model (7) makes alpha for growth/income funds to decrease from $-0.46 \%$ to a significant under-performance of $0.79 \%$. The decrease in alpha for income funds is even more dramatic, from a $-0.13 \%$ for model (1) to a significant $-1.93 \%$ per year when using the Carhart model (7). 


\begin{tabular}{|c|c|c|c|c|c|c|c|c|c|c|}
\hline Model & Alpha & Market & SMB & HML & PRIYR & Bond & $\mathrm{R}_{\text {all }}^{2}$ & $\log L$ & $\begin{array}{r}\text { Significant } \\
\text { increase in Log } L \\
\text { to previous } \\
\text { model? }\end{array}$ & $\begin{array}{r}\text { Significant } \\
\text { increase in Log } L \\
\text { to unconditional } \\
\text { model ? }\end{array}$ \\
\hline (1) Unconditional CAPM & -0.17 & $1.01^{100}$ & & & & & 0.94 & 1922.81 & & \\
\hline (2) Unconditional FF & 0.57 & $0.95^{\cdots \cdots}$ & $0.21 \ldots$ & $-0.07^{* \cdots}$ & & & 0.96 & 2024.60 & Yes & \\
\hline (3) Unconditional FF + Momentum & -0.05 & $0.95^{\ldots \ldots}$ & $0.22 \ldots$ & $-0.05 \cdots$ & $0.04^{\cdots \cdots}$ & & 0.97 & 2031.38 & Yes & \\
\hline $\begin{array}{l}\text { (4) Unconditional FF + Momentum + } \\
\text { Bond }\end{array}$ & -0.09 & $0.96^{* \cdots}$ & $0.21^{\cdots}$ & $-0.05^{* *}$ & $0.04^{\cdots \cdots}$ & $-0.04^{*}$ & 0.97 & 2032.88 & No & \\
\hline (5) Conditional CAPM & 0.26 & & & & & & 0.94 & 1928.77 & & Yes \\
\hline (6) Conditional FF & $0.82^{\circ}$ & & & & & & 0.97 & 2077.74 & Yes & Yes \\
\hline (7) Conditional FF + Momentum & 0.14 & & & & & & 0.97 & 2096.26 & Yes & Yes \\
\hline (8) Conditional FF + Momentum + Bond & 0.09 & & & & & & 0.98 & 2104.93 & Yes & Yes \\
\hline $\begin{array}{l}\text { (9) Conditional FF + Momentum + Bond + } \\
\text { Conditional Alpha }\end{array}$ & & & & & & & 0.98 & 2106.19 & No & \\
\hline \multicolumn{11}{|c|}{$\begin{array}{l}\text { Notes: Table } 4.3 \text { reports OLS estimates for the } 9 \text { different models we employ. As input we use an equally weighted portfolio of surviving mutual funds in our sample. That is, } \\
\text { we exclude dead funds. For each model we provide an annualized alpha, betas, R } \mathrm{R}_{\text {wd }} \text { and loglikelihood. The last two columns provide an answer to the question whether the } \\
\text { explanatory of the new model differs significantly from the previous model (column } 10 \text { ) and whether it differs from the corresponding unconditional model (column } 11 \text { ). If } 2 \\
\text { times the difference in Log } L \text { between two models exceeds the corresponding critical value of a } \chi^{2} \text { ss (df) we report a "Yes". If not, a "No" is reported, indicating that the new } \\
\text { model does not significantly add explanatory value in assessing mutual fund performance. } \\
\text { significant at the } 1 \% \text { level. } \\
\text { significant at the } 5 \% \text { level. } \\
\text { significant at the } 10 \% \text { level. }\end{array}$} \\
\hline
\end{tabular}


Table 4.4: Empirical Results on investment style level: 1962:01 - 2000:12

Significant

increase in $\log L$

Significant

Model

Alpha Market

SMB

HML PRIYR

Bond

$R^{2}$

model ?

to unconditional

\section{AGGRESSIVE GROWTH}

(1) Unconditional CAPM

(2) Unconditional FF

$-0.78 \quad 1.18^{m}$

(3) Unconditional FF + Momentum

$0.49 \quad 1.02^{\cdots *}$

(4) Unconditional FF + Momentum + Bond

$1.02^{* *}$

$0.51^{\cdots}$

$0.51^{\cdots}$

$-0.15 \cdots$

$1.04^{\cdots *} \quad 0.54^{\cdots *}$

-0.12
$-0.12^{\cdots}$

$0.10^{\cdots *}$

$0.10^{\ldots . .}$

$-0.03^{\circ}$

$\begin{array}{ll}0.87 & 1508.79\end{array}$

$0.96 \quad 1736.33$

$0.96 \quad 1758.72$

$0.96 \quad 1759.87$

Yes

(5) Conditional CAPM

$-0.47$

(6) Conditional FF

0.94

(7) Conditional FF + Momentum

$-0.63$

(8) Conditional FF + Momentum + Bond

$-0.60$

$0.87 \quad 1514.24$

$0.97 \quad 1780.38$

$0.97 \quad 1822.92$

$0.97 \quad 1825.50$

$0.97 \quad 1826.53$

Conditional Alpha

\section{GROWTH}

(1) Unconditional CAPM

(2) Unconditional FF

(3) Unconditional FF + Momentum

(4) Unconditional FF + Momentum + Bond

$-0.01$

$-0.01$

0.42
-0.28

$0.94^{\circ+0}$

$0.89^{* \cdots}$

$0.89^{\cdots}$

$0.14^{* * *}$

$-0.07^{\cdots *}$

$0.90^{\cdots *}$

$0.14^{\cdots}$

$-0.05 \cdots$

$-0.05^{\cdots . .}$

$0.05 \cdots$

$0.90 \quad 1983.00$

$0.91 \quad 2014.94$

$0.92 \quad 2019.47$

$0.92 \quad 2022.55$

Yes

(5) Conditional CAPM

0.01

(6) Conditional FF

0.47

(7) Conditional FF + Momentum

0.47
-0.09

(8) Conditional FF + Momentum + Bond

(9) Conditional FF + Momentum + Bond +

$0.90 \quad 1991.96$

$0.92 \quad 2037.56$

$0.93 \quad 2047.44$

$0.93 \quad 2056.35$

$0.94 \quad 2057.52$

Conditional Alpha 


\begin{tabular}{|c|c|c|c|c|c|c|c|c|c|c|}
\hline Model & Alpha & Market & SMB & HML & PRIYR & Bond & $\mathbf{R}^{2}$ at & $\log L$ & $\begin{array}{r}\text { Significant } \\
\text { increase in Log } L \\
\text { to previous } \\
\text { model? }\end{array}$ & $\begin{array}{r}\text { Significant } \\
\text { increase in Log } L \\
\text { to unconditional } \\
\text { model ? }\end{array}$ \\
\hline \multicolumn{11}{|l|}{ GROWTH / INCOME } \\
\hline (1) Unconditional CAPM & -0.46 & 0.92 & & & & & 0.96 & 2231.51 & & \\
\hline (2) Unconditional FF & $-0.91^{* *}$ & $0.96^{* \ldots}$ & $-0.09^{\cdots}$ & $0.07^{\cdots *}$ & & & 0.97 & 2286.16 & Yes & \\
\hline (3) Unconditional FF + Momentum & $-0.66^{\circ}$ & $0.96^{\ldots . .}$ & $-0.10^{\ldots}$ & $0.07^{* \ldots *}$ & $-0.02^{\circ}$ & & 0.97 & 2287.92 & No & \\
\hline (4) Unconditional FF + Momentum + Bond & $-0.68^{\circ}$ & $0.96^{* \cdots}$ & $-0.10^{* \cdots}$ & $0.07^{\cdots *}$ & $-0.02^{\circ}$ & -0.02 & 0.97 & 2288.86 & No & \\
\hline (5) Conditional CAPM & $-0.69^{\circ}$ & & & & & & 0.97 & 2248.58 & & Yes \\
\hline (6) Conditional FF & $-0.89^{* *}$ & & & & & & 0.98 & 2375.27 & Yes & Yes \\
\hline (7) Conditional FF + Momentum & $-0.79^{* \cdots}$ & & & & & & 0.98 & 2389.01 & Yes & Yes \\
\hline (8) Conditional FF + Momentum + Bond & $-0.79^{\cdots}$ & & & & & & 0.98 & 2391.71 & No & Yes \\
\hline $\begin{array}{l}\text { (9) Conditional FF + Momentum + Bond + } \\
\text { Conditional Alpha }\end{array}$ & & & & & & & & 2392.85 & No & \\
\hline \multicolumn{11}{|l|}{ INCOME } \\
\hline (1) Unconditional CAPM & -0.13 & $0.72^{000}$ & & & & & 0.82 & 1233.51 & & \\
\hline (2) Unconditional FF & $-2.31^{\cdots *}$ & $0.83^{\cdots \cdots}$ & $-0.15^{\ldots *}$ & $0.27^{\cdots *}$ & & & 0.90 & 1315.52 & Yes & \\
\hline (3) Unconditional FF + Momentum & $-1.52^{\circ}$ & $0.83^{\cdots}$ & $-0.16 \ldots$ & $0.25 \cdots$ & $-0.05^{\cdots *}$ & & 0.90 & 1319.50 & Yes & \\
\hline (4) Unconditional FF + Momentum + Bond & $-1.52^{\circ}$ & $0.83^{\cdots *}$ & $-0.16^{* *}$ & $0.25^{\cdots *}$ & $-0.05^{\cdots *}$ & 0.00 & 0.90 & 1319.50 & No & \\
\hline (5) Conditional CAPM & -0.91 & & & & & & 0.84 & 1248.71 & & Yes \\
\hline (6) Conditional FF & $-2.75^{\cdots}$ & & & & & & 0.92 & 1361.77 & Yes & Yes \\
\hline (7) Conditional FF + Momentum & $-1.93^{\ldots}$ & & & & & & 0.93 & 1370.44 & Yes & Yes \\
\hline (8) Conditional FF + Momentum + Bond & $-1.86^{\cdots *}$ & & & & & & 0.93 & 1376.07 & Yes & Yes \\
\hline $\begin{array}{l}\text { (9) Conditional FF + Momentum + Bond + } \\
\text { Conditional Alpha }\end{array}$ & & & & & & & 0.93 & 1384.81 & Yes & \\
\hline \multicolumn{11}{|c|}{$\begin{array}{l}\text { Notes: Table } 4.4 \text { reports OLS estimates for the } 9 \text { different models we employ. As input we use } 4 \text { equally weighted portfolios of mutual funds, based on self-reported } \\
\text { investment styles. For each model we provide an annualized alpha, betas, } R_{\text {adj }} \text { and loglikelihood. The last two columns provide an answer to the question whether the } \\
\text { explanatory of the new model differs significantly from the previous model (column } 10 \text { ) and whether it differs from the corresponding unconditional model (column } 11 \text { ). If } 2 \\
\text { times the difference in Log } L \text { between two models exceeds the corresponding critical value of a } \chi^{2} \text { s (df) we report a "Yes". If not, a "No" is reported, indicating that the new } \\
\text { model does not significantly add explanatory value in assessing mutual fund performance. } \\
\text { significant at the } 1 \% \text { level. "significant at the } 5 \% \text { level. "significant at the } 10 \% \text { level. }\end{array}$} \\
\hline
\end{tabular}


Figure 4.2: Time-varying alpha and beta for the income portfolio, 1962:01-2000:12

Apta

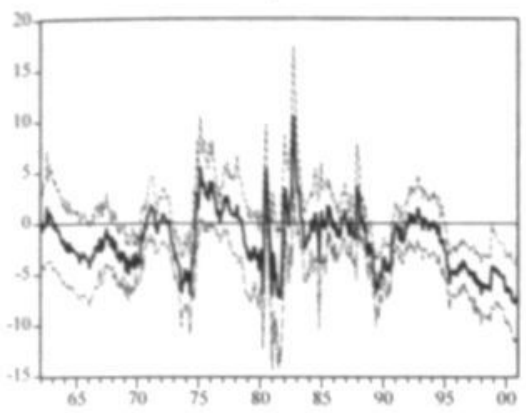

SMB

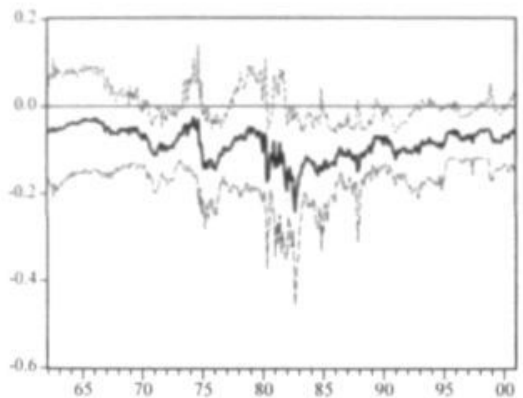

PRIYR

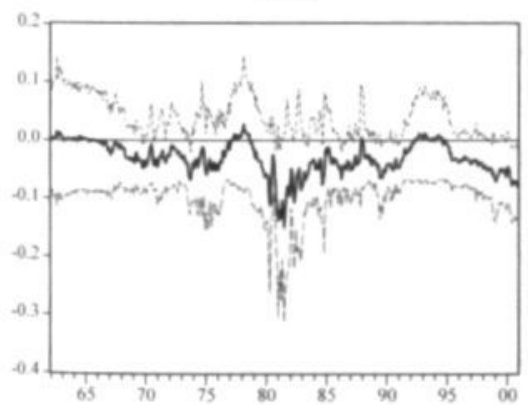

Market

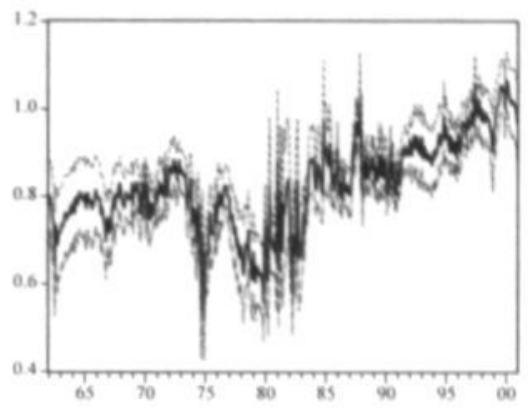

HMI

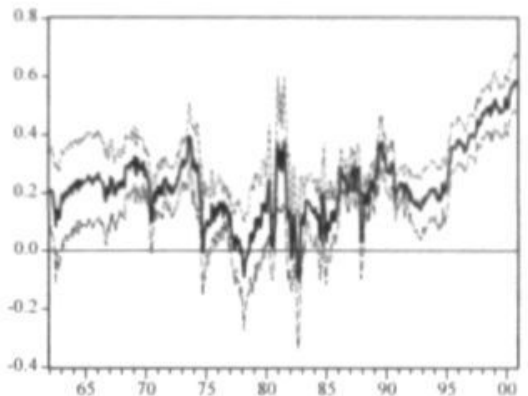

Boed

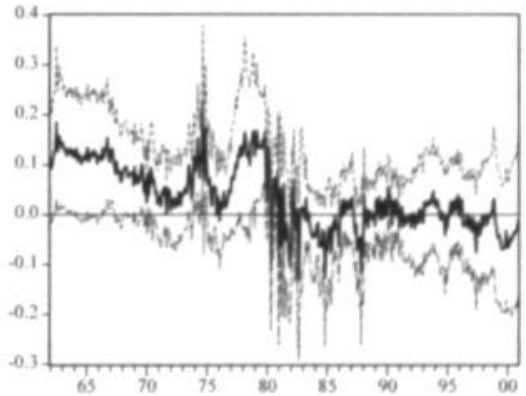

Notes: This figure presents the time-varying alpha, market beta, SMB, HML, PRIYR and Bond for the income portfolio. In order to introduce time-variation we allow the alpha, market beta, SMB, HML, PRIYR and Bond to vary over time as a function of (1) the 1 month T-bill rate, (2) dividend yield (3) the slope of the term structure and (4) the quality spread. Given are the time-varying parameter estimates (solid line), while $95 \%$ confidence bounds are indicated using dashed lines. 


\subsection{Discussion of the Results and Conclusion}

During the past 30 years the ability of mutual fund managers to beat the market gave rise to a fierce debate. For example Jensen (1968) and Sharpe (1966) argue mutual funds underperform the market by the amount of expenses they charge the investor. Ippolito (1989) however documented significantly positive risk-adjusted net returns of US mutual funds. More recently several authors argued the prior studies where either subject to data biases (survivorship) and/or model misspecification. For instance it was argued that also nonS\&P500 holdings and time-variation in risk and return must be accounted for.

This chapter provides a comprehensive assessment of existing mutual fund performance models, using a survivor-bias free database of all US mutual funds. Starting with the most basic single factor CAPM model, we then explore the added value of introducing extra variables like size, book-to-market, momentum and a bond index. In addition to that we evaluate the use of introducing time-variation in betas and alpha. Our main goal is to determine which model is best suitable to measure mutual fund performance. This is done by assessing both the statistical and economic relevance of a range of model specifications. The added value of this study lies both in the step-wise process of adding new factors, and the use of a rich US mutual fund database.

Our results reveal five major conclusions. First, we document a severe survivorship bias if dead funds are not included in the database. This leads to a significant overestimation of raw returns of $0.51 \%$ and an overestimation of alphas of up to $0.64 \%$ per year. Second, within an unconditional setting we find the 4-factor model, including market beta, SMB, HML and PRIYR momentum is best able to explain mutual fund returns. Third, conditioning betas on publicly available information proves to be a strong improvement in mutual fund performance measurement. All conditional models are superior to their unconditional peers. Within the conditional setting the 4-factor model is again statistically the strongest model. Fourth, we find only very little evidence of time-variation in fund alphas. Only at the investment style level the portfolio containing funds in the income style exhibits timevariation in alpha. Fifth, at the aggregate level, 'all funds portfolio', the alpha estimate does not change that much when going from an unconditional CAPM model (1) to for instance a conditional Carhart model (7). At the investment style level however, the economic relevance of using a more elaborate model is more significant. 2 out of 4 portfolios exhibit significant under-performance when using the conditional 4-factor model, while using the unconditional CAPM model their performance was indistinguishable from zero.

Returning now to the question which model to use for performance measurement, we will again make distinguish between statistical and economic relevance. Purely based on statistical significance, the more elaborate multi-factor conditional models are clearly superior to the unconditional models. If we however consider the economic relevance of the elaborate 
models another conclusion can be drawn. When measuring performance at an aggregated level the influence of using elaborate conditional models is not that obvious. At the investment style level however, the use of richer models does have a clear impact on alpha estimates for a great deal of funds. In addition it can be said that conditional models add strong economic relevance because of the ability to detect patterns in fund betas. This enables the investor to monitor the dynamic behavior of mutual fund managers.

In the next chapter we will apply these more elaborate model specifications again on European mutual funds. Besides measuring performance we explore persistence, survivorship bias and the influence of fund characteristics on the relative performance of European mutual funds. 


\section{Chapter 5}

\section{European Mutual Fund Performance ${ }^{30}$}

\subsection{Introduction}

After exploring the structure of the European mutual fund industry in chapter 3, this chapter will be mainly devoted to the performance of European funds. Based on the results in chapter 4, we will evaluate European fund performance using more elaborate model specifications.

By the end of 1998 the US mutual fund industry reached record levels with almost \$ 5.2 trillion in assets. With the number of mutual funds being $60 \%$ larger than the number of listed securities and a $20 \%$ stake in total US financial assets, the attention mutual funds get in both the financial press and academia seems justified. Numerous academics for instance addressed the performance of professional money managers.

Starting with Jensen (1969), most academic studies conclude that the net performance of mutual funds (after expenses) is inferior to that of a comparable passive market proxy. During the late 80 s and early 90 s however some contradictory studies emerged. Grinblatt \& Titman (1989, 1992) and Ippolito (1989) found mutual funds did posses enough private information to offset the expenses they made. Moreover Hendricks, Patel \& Zeckhauser (1993), Goetzmann \& Ibbotson (1994) and Brown \& Goetzmann (1995) find evidence of persistence in mutual fund performance over short-term horizons. Carhart (1997) however argues that this effect is mainly attributable to simple momentum strategies, and not to superior fund management.

In two recent overview articles, Malkiel (1995) and Gruber (1996) claim that most of the older studies are subject to survivorship bias. When they adjust for this effect it is argued

\footnotetext{
${ }^{30}$ This Chapter is based on R. Otten and D. Bams, 'European Mutual Fund Performance', European Financial Management, Vol. 8(1), 2002, pp. 75-101
} 
that mutual funds on average under-perform the market proxy, by the amount of expenses they charge the investor. Investing in a low cost index fund accordingly is preferred over choosing an actively managed fund.

All of these studies focus on the US market as long-term data is available and investor interest is well developed. The European market for mutual funds however lags the US market when it comes to both size and market importance. Nevertheless during the last 5 years the European market has experienced large inflows, which encourages us to carry out this study on European mutual fund performance evaluation.

As far as we know the only comprehensive study on European mutual fund performance is conducted by Grübichler \& Pleschiutschnig (1999). They investigate performance persistence by looking at a sample of surviving funds, investing in the European region. This study however will focus on the performance of European funds (both dead and surviving) only investing in their domestic market. We think this allows us to dig deeper into the determinants of mutual fund performance and enables us to consider the influence of investment style on fund performance. For instance to investigate whether the specialization of mutual fund companies into growth or small cap stocks is based on any unique skill, or whether this is simply a marketing strategy to attract capital.

Although comprehensive European research is scarce, several authors have studied individual countries. For instance Dermine (1992) and McDonald (1973) study French mutual funds, Shukla \& Imwegen (1995), Ward \& Saunders (1976) and Blake \& Timmerman (1998) consider UK funds. German funds are evaluated by Wittrock \& Steiner (1995). Dutch funds are examined in Ter Horst, Nijman \& De Roon (1998), and finally Dahlquist, Engström and Söderlind (2000) consider Swedish mutual funds.

The purpose of this chapter is to give an overview of the largely unexploited European mutual fund area. To do this we evaluate fund performance using a survivorship bias controlled database that consists of 506 mutual funds from 5 different European countries. ${ }^{31}$ Applied are both unconditional and conditional versions of the Carhart (1997) 4-factor model. In addition we investigate whether past performance predicts future performance, the socalled "hot hands effect". Finally the influence of several fund characteristics (e.g. management expenses, fund assets, age) on risk-adjusted performance is considered.

Our overall results suggest that European mutual funds, and especially small cap funds are able to add value, as indicated by their positive after cost alphas. If we add back management expenses (before cost alphas) 4 out of 5 countries exhibit significant outperformance at an aggregate level. Finally we detect strong persistence in mean returns for funds investing in the United Kingdom. The strategy of buying last years winners and selling last years losers yields a return of $6.08 \%$ per year, which cannot be explained by common factors in stock returns.

\footnotetext{
${ }^{31}$ This database is similar to the one used in chapter 3, only the sample period now runs through 12-1998.
} 
The remainder of this chapter is organized as follows. In section 5.2 some basic features of the European mutual fund industry are presented. Section 5.3 provides information on the data. The performance of European mutual funds will be discussed in section 5.4. Section 5.5 considers persistence in performance, while section 5.6 explores the influence of fund characteristics on risk-adjusted performance. Section 5.7 concludes the chapter.

\subsection{The European Mutual Fund Industry}

By the end of 1998 there was $\$ 2.66$ trillion of assets under management in European mutual funds. This is about half the size of the US industry, which had almost \$ 5.2 trillion in assets by the end of $1998 .^{32}$ From table 5.1 some more interesting features of the European mutual fund industry arise. As a proxy for the European market we consider the 6 most important European mutual fund markets. Together they account for almost $90 \%$ of total mutual fund assets in Europe.

Table 5.1: Characteristics of Major Mutual Fund Markets

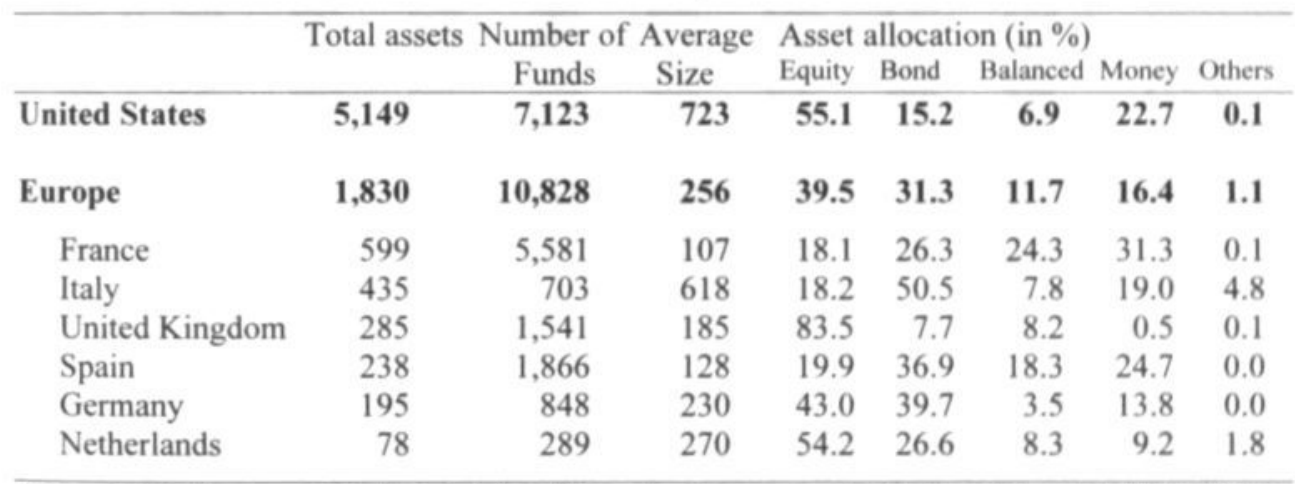

Notes: This table presents the characteristics of the major European mutual fund markets and the United States. All figures are obtained from FEFSI and are of December 31, 1998. The first column presents the total market value (million US dollar). The second column the number of funds, the third column the average size and the last 5 columns the asset allocation of all mutual funds.

It appears that while the 6 most important European mutual fund markets together account for less than half of the US mutual fund market, the European number of funds exceeds the US number of funds. If we combine the smaller total market size and the higher number of funds it is evident that the average size of the European mutual fund is much smaller than the average size of the US fund, \$256 million as opposed to the average US fund which has \$723 million in assets. Another striking difference between the US and the European mutual fund market is the dominance of equity-oriented funds in the US, while European investors also

\footnotetext{
${ }^{32}$ See FEFSI statistics 1999.
} 
invest heavily in bond funds. Like already stated in chapter 3, we suspect this is due to a different equity culture, strong presence of banks and a different pension system. Figure 5.1 however puts this observation into perspective. It gives the development of the asset allocation of European mutual funds through time. From this table it becomes clear that the percentage of assets invested in equity mutual funds actually has been rising dramatically from just over $10 \%$ in 1990 to almost $40 \%$ in 1998 . This increase has mainly been at the expense of money market funds, which possessed $40 \%$ of the market in 1990 and only $16.4 \%$ in 1998 .

Figure 5.1: Asset Allocation of European mutual funds through time, 1990 - 1998

$100 \%$
$90 \%$
$80 \%$
$70 \%$
$60 \%$
$50 \%$
$40 \%$
$30 \%$
$20 \%$
$10 \%$
$0 \%$

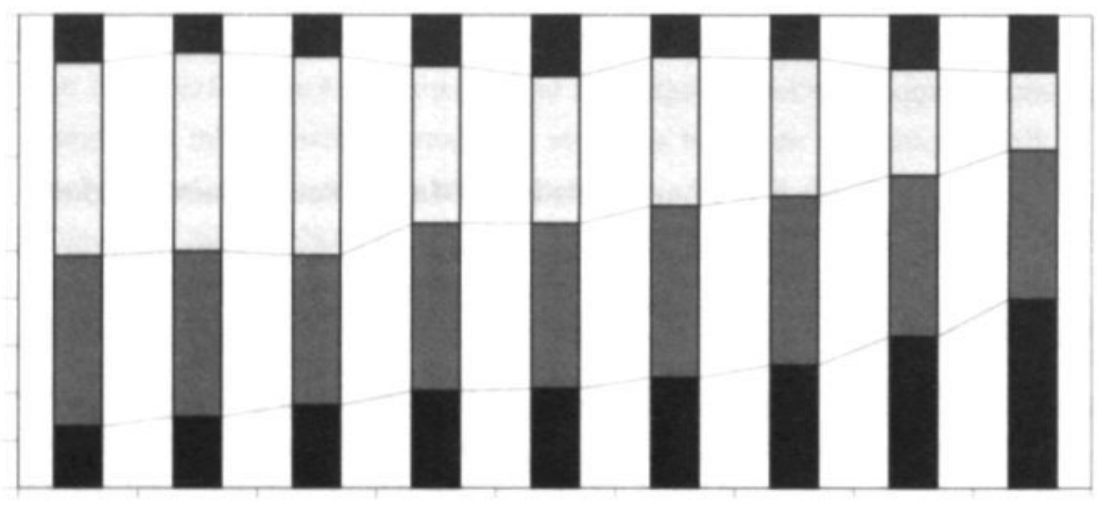

$1990 \quad 1991 \quad 1992 \quad 1993 \quad 1994 \quad 1995 \quad 1996 \quad 1997 \quad 1998$
E quity
$\square$ B o n d
M M
B a la nced

Notes: Figure 5.1 provides the average asset allocation of the six main European mutual fund markets, being France, Germany, Italy, the Netherlands, Spain and the United Kingdom. Data are from 12/90 through 12/98 and are obtained from FEFSI Statistics 1999.

The results from the previous paragraph indicate that the European (equity) mutual fund market is smaller than the market in the United States. However, it is not necessarily true that Europeans have less exposure to the equity market as they can also purchase equities themselves or through other institutions like pension funds and insurance companies. Table 2 presents a statistic that indicates the importance of equity mutual funds at their domestic equity market. The statistic is calculated as the total market value of all equity mutual funds divided by the domestic market capitalization. The 1998 figure for the United States is $27 \%$, which is roughly two-and-a-half times as big as the average European figure. Therefore the European mutual fund sector is indeed not as important as its American counterpart indicating 
that individuals possibly purchase equities through other channels. Finally the increasing importance of the mutual fund sector in general can be derived from the increasing percentage through time, both in the United States and in Europe.

Table 5.2: Equity mutual funds as a percentage of total stock market capitalization

\begin{tabular}{|c|c|c|c|c|c|c|c|}
\hline & 1992 & 1993 & 1994 & 1995 & 1996 & 1997 & 1998 \\
\hline United States & $16 \%$ & $20 \%$ & $22 \%$ & $26 \%$ & $28 \%$ & $26 \%$ & $27 \%$ \\
\hline Europe & $6 \%$ & $8 \%$ & $8 \%$ & $8 \%$ & $8 \%$ & $11 \%$ & $11 \%$ \\
\hline France & $13 \%$ & $12 \%$ & $13 \%$ & $11 \%$ & $11 \%$ & $11 \%$ & $12 \%$ \\
\hline Germany & $3 \%$ & $5 \%$ & $7 \%$ & $7 \%$ & $6 \%$ & $8 \%$ & $8 \%$ \\
\hline Italy & $8 \%$ & $9 \%$ & $12 \%$ & $11 \%$ & $9 \%$ & $13 \%$ & $14 \%$ \\
\hline Netherlands & $6 \%$ & $8 \%$ & $7 \%$ & $9 \%$ & $9 \%$ & $10 \%$ & $10 \%$ \\
\hline Spain & $0 \%$ & $1 \%$ & $1 \%$ & $1 \%$ & $2 \%$ & $9 \%$ & $14 \%$ \\
\hline United Kingdom & $10 \%$ & $11 \%$ & $11 \%$ & $11 \%$ & $10 \%$ & $11 \%$ & $11 \%$ \\
\hline
\end{tabular}

\subsection{Data}

\subsubsection{European Mutual Funds}

To study the performance of European mutual funds we construct a database containing the 5 most important mutual fund countries, being France, Germany, Italy, The Netherlands and the United Kingdom. Together these countries cover over $85 \%$ of total assets in European funds. ${ }^{33}$ We restrict our sample to pure domestic equity funds with at least 24 months of data. That is, we exclude balanced and guaranteed funds and equity funds that invest internationally. This leads to a sample of 506 open-ended equity mutual funds with monthly logarithmic returns from January 1991 through December 1998. All returns are in local currency.

To obtain information on the characteristics of the individual equity funds we use several sources: Standard \& Poor's Micropal (France, Italy), Hoppenstedt Fondsfürer 1998 (Germany), ABN-AMRO Beleggingsinstellingen (Netherlands) and the Unit Trust Yearbook 1998 (United Kingdom). Collected are fund type or investment style, size, age and management fees. Within a country we divide all funds using stated investment styles to test whether this yields differences in performance. Return data are collected from Datastream (Germany, Italy, the Netherlands and the United Kingdom) and Standard \& Poor's Micropal (France). All returns are inclusive of any distributions, net of annual management fees and in local currency.

\footnotetext{
${ }^{33}$ For Spain no comprehensive return data was available.
} 
As several studies have shown before (see for example Brown et al. (1992)), survivorship issues can influence the results severely, that is when a database consists only of funds that have data available during the whole sample period. This derives from the fact that funds with bad performance are frequently being shut down or merged into another one. This gives an overestimation of the average performance as only surviving funds are evaluated. The only specialized commercial vendor of European mutual fund data, Standard \& Poor's Micropal, however only collects data on surviving funds. It therefore is impossible to create a survivorship bias free database using this source. To circumvent this problem we use Datastream, which does collect data on dead funds for most countries. Through the national mutual fund publications (for instance the Unit Trust Yearbook for the UK) we were able to track dead funds. Return data for these funds was then collected from Datastream. Dead funds were included in the sample until they disappeared. After that the portfolios are re-weighted accordingly.

The percentage of disappearing funds through out the sample period for Germany, Italy, the Netherlands and the United Kingdom was respectively $5 \%, 6 \%, 11 \%$ and $25 \%{ }^{34}$ The influence of this becomes apparent if we compare the mean returns of all funds (dead + surviving) with the return on surviving funds only. Restricting our sample to surviving funds would lead us to overestimate average returns by $0.12 \%$ (Germany), $0.45 \%$ (Italy), $0.11 \%$ (Netherlands) and $0.15 \%$ (United Kingdom) per year. Note that the overestimation for European funds is less severe than the $0.51 \%$ survivor bias for US funds found in chapter 4 . Table 5.3 gives a first impression of the European data we use in our subsequent analyses.

\subsubsection{Benchmarks}

In constructing our (European) version of the Carhart (1997) 4-factor model we consider all stocks that are in the Worldscope universe for each country. ${ }^{35}$ For the excess market return we take all stocks in the Worldscope universe that are larger than $\$ 25$ million, minus the 1month interbank rate. ${ }^{36}$ We then rank all stocks based on size and assign the bottom $20 \%$ of total market capitalization to the small portfolio. The remaining part goes into the large portfolio. SMB is the return difference between small and large. For the HML factor all stocks are ranked on their book-to-market ratio. The top $30 \%$ of market capitalization is assigned to the high book-to-market portfolio and the bottom $30 \%$ to the low book-to-market

\footnotetext{
${ }^{34}$ Because Datastream does not cover French mutual funds we had to rely on Standard \& Poor's Micropal for our French sample. As this source does not collect data on dead funds the French sample is possibly subject to survivorship bias.

${ }_{15}$ Worldscope covers over $98 \%$ of total market capitalization per country. Which is much broader than the average $\mathrm{MSCl}$ index $(70 \%)$.

36 Instead of Worldscope we also used similar local indices like the CAC40, DAX30, Mibtel, AEX and FTAllshare to test for benchmark sensitivity. We found this did not alter our conclusions.
} 
portfolio. HML is obtained by subtracting the low from the high book-to-market return. The momentum

Table 5.3: Summary Statistics for European mutual funds 1991-1998

\begin{tabular}{|c|c|c|c|c|c|}
\hline & $\begin{array}{l}\text { No } \\
\text { Funds }\end{array}$ & $\begin{array}{l}\text { Mean } \\
\text { Return }\end{array}$ & Stdev & Size & $\begin{array}{l}\text { Exp. } \\
\text { ratio }\end{array}$ \\
\hline \multicolumn{6}{|l|}{ France } \\
\hline Growth & 55 & 10.9 & 14.2 & 396 & 1.1 \\
\hline Index & 20 & 10.0 & 17.3 & 65 & 1.2 \\
\hline Smaller Companies & 24 & 11.8 & 14.3 & 81 & 1.3 \\
\hline All funds & 99 & 10.9 & 14.8 & 258 & 1.2 \\
\hline \multicolumn{6}{|l|}{ Germany } \\
\hline General & 45 & 14.3 & 17.6 & 369 & 0.8 \\
\hline Growth & 5 & 12.5 & 17.5 & 125 & 0.8 \\
\hline Income & 2 & 15.0 & 18.4 & 660 & 1.0 \\
\hline Smaller Companies & 5 & 11.0 & 15.5 & 121 & 0.9 \\
\hline All funds & 57 & 13.9 & 17.5 & 335 & 0.8 \\
\hline \multicolumn{6}{|l|}{ Italy } \\
\hline Italian equity & 21 & 14.2 & 18.2 & 261 & 2.0 \\
\hline Italian specialist & 16 & 16.5 & 21.3 & 223 & 1.8 \\
\hline All funds & 37 & 15.2 & 19.6 & 242 & 2.0 \\
\hline \multicolumn{6}{|l|}{ Netherlands } \\
\hline Growth & 5 & 22.1 & 16.2 & 500 & 0.6 \\
\hline Index & 3 & 23.0 & 21.3 & 50 & 0.4 \\
\hline Smaller Companies & 1 & 18.0 & 15.5 & 505 & 0.6 \\
\hline All funds & 9 & 22.0 & 16.6 & 350 & 0.5 \\
\hline \multicolumn{6}{|l|}{ United Kingdom } \\
\hline Growth/Income & 79 & 12.6 & 13.6 & 326 & 1.1 \\
\hline Income & 72 & 12.6 & 13.6 & 260 & 1.2 \\
\hline Growth & 102 & 12.8 & 13.7 & 215 & 1.3 \\
\hline Smaller Companies & 51 & 10.5 & 14.9 & 222 & 1.3 \\
\hline All funds & 304 & 12.3 & 13.9 & 256 & 1.2 \\
\hline
\end{tabular}


factor portfolio is formed by ranking all stocks on their prior 6-month return. ${ }^{37}$ The return difference between the top $30 \%$ and bottom $30 \%$ by market capitalization then provides us with the Pr6m factor returns. Summary statistics on these portfolios are displayed in table 5.4.

\subsection{Performance Measurement}

\subsubsection{Mutual Fund Performance Models}

Most mutual fund studies prior to the 90's make use of a CAPM based single index model. ${ }^{38}$ The intercept of such a model, $\alpha_{i}$, gives the Jensen alpha, which is usually interpreted as a measure of out- or under-performance relative to the used market proxy. ${ }^{39}$

$$
R_{i t}-R_{f t}=\alpha_{i}+\beta_{i}\left(R_{m t}-R_{f t}\right)+\varepsilon_{i t}
$$

where $R_{i t}$ is the return on fund $i$ in month $t, R_{f}$ the return on a one month T-bill in month $t$, $R_{m t}$ the return on the local equity benchmark in month $t$ and $\varepsilon_{i t}$ an error term. Such a CAPM based model however assumes that a fund's investment hehavior can he annroximated using only one single market index. Because of the wide diversity of stated investment styles, ranging from growth to small cap, it is however preferable to use a multi-factor model to account for all possible investment strategies.

The rationale for using a multi-factor asset-pricing model lies in the recent literature on the cross-sectional variation of stock returns (see, e.g. Fama \& French $(1993,1996)$ and Chan, Jegadeesh \& Lakonishok (1996)). The results of these studies lead us to question the adequacy of a single index model to explain mutual fund performance. Therefore the Fama \& French (1993) 3-factor model has been considered to give a better explanation of fund behavior. Besides a value-weighted market proxy two additional risk factors are used, size and book-to-market. Although this model already improves average CAPM pricing errors, it is not able to explain the cross-sectional variation in momentum-sorted portfolio returns. Therefore Carhart (1997) extends the Fama-French model by adding a fourth factor that captures the Jegadeesh \& Titman (1993) momentum anomaly. The resulting model is consistent with a market equilibrium model with four risk factors, which can also be interpreted as a performance attribution model, where the coefficients and premia on the factor-mimicking portfolios indicate the proportion of mean return attributable to four elementary strategies.

\footnotetext{
${ }^{37}$ We choose not to use the 12-month momentum to stick as close as possible to Rouwenhorst (1998), who uses a 6- month momentum in his analysis of European momentum strategies.

${ }^{38}$ For an overview see Ippolito (1989)

${ }^{39}$ See Jensen (1968)
} 
Table 5.4: Summary statistics for Carhart 4-factor model benchmarks, 1991-1998

\begin{tabular}{|c|c|c|c|c|c|c|}
\hline \multirow{2}{*}{$\begin{array}{l}\text { Factor } \\
\text { Portfolio }\end{array}$} & \multirow{2}{*}{$\begin{array}{l}\text { Excess } \\
\text { Return }\end{array}$} & \multirow{2}{*}{$\begin{array}{l}\text { Standard } \\
\text { deviation }\end{array}$} & \multicolumn{4}{|c|}{ Cross correlations } \\
\hline & & & Market & SMB & HML & PR6m \\
\hline \multicolumn{7}{|l|}{ France } \\
\hline Market & 3.57 & 15.08 & 1.00 & & & \\
\hline SMB & -2.96 & 12.99 & -0.16 & 1.00 & & \\
\hline $\mathrm{HML}$ & -2.24 & 11.21 & 0.16 & -0.10 & 1.00 & \\
\hline PR6m & -1.43 & 9.98 & -0.30 & -0.35 & -0.44 & 1.00 \\
\hline
\end{tabular}

\section{Germany}

$\begin{array}{lrrrrrr}\text { Market } & 7.38 & 15.24 & 1.00 & & & \\ \text { SMB } & -7.99 & 8.84 & -0.59 & 1.00 & & \\ \text { HML } & 4.03 & 9.41 & -0.03 & 0.06 & 1.00 & \\ \text { PR6m } & -0.14 & 10.23 & 0.18 & -0.35 & -0.41 & 1.00\end{array}$

\section{Italy}

$\begin{array}{lcrrrrr}\text { Market } & 4.92 & 25.04 & 1.00 & & & \\ \text { SMB } & -6.20 & 12.35 & -0.20 & 1.00 & & \\ \text { HML } & 1.87 & 13.10 & 0.24 & 0.49 & 1.00 & \\ \text { PR6m } & 12.00 & 14.55 & 0.01 & -0.28 & -0.33 & 1.00\end{array}$

\section{Netherlands}

$\begin{array}{lrrrrrr}\text { Market } & 14.59 & 14.98 & 1.00 & & & \\ \text { SMB } & -4.57 & 8.17 & -0.16 & 1.00 & & \\ \text { HML } & -0.41 & 12.15 & 0.27 & 0.30 & 1.00 & \\ \text { PR6m } & 9.02 & 11.81 & -0.05 & -0.31 & -0.40 & 1.00\end{array}$

\section{United Kingdom}

\begin{tabular}{lrrrrrr} 
Market & 7.49 & 13.58 & 1.00 & & & \\
SMB & -4.86 & 11.31 & -0.10 & 1.00 & 1.00 & \\
HML & -3.24 & 8.67 & 0.15 & 0.34 & -0.46 & 1.00 \\
PR6m & 11.49 & 9.24 & -0.18 & -0.36 & -0.46 \\
\hline
\end{tabular}

Notes: The Market factor is the return on the total Universe of the individual countries according to Worldscope. Companies smaller than \$25 million are excluded. Number of companies; France (936), Germany (829), Italy (323), Netherlands (244), United Kingdom (2454). The excess return is calculated by subtracting the 1-month interbank rate. The SMB factor is constructed as the difference between the bottom $20 \%$ of market capitalization ranked by size minus the top $80 \%$ of market capitalization. HML is obtained by ranking all companies by their book-to-market and then take the return difference between the top 30\% of market capitalization and the bottom 30\%. PR6m is constructed by ranking all stocks on prior six months return and then take the top $30 \%$ of market capitalization minus the bottom $30 \%$. All portfolios are cap weighted and rebalanced annually, except for the Pr6m portfolio which is rebalanced every 6 months. Returns and standard deviations are stated as annual figures in the table. 
Formally:

$$
R_{i t}-R f_{t}=\alpha_{i}+\beta_{0 i}\left(R m_{t}-R f_{t}\right)+\beta_{1 i} S M B_{t}+\beta_{2 i} H M L_{t}+\beta_{3 i} P R 6 m_{t}+\varepsilon_{i t}
$$

where

$\begin{array}{ll}\mathrm{SMB}= & \begin{array}{l}\text { the difference in return between a small cap portfolio and a } \\ \text { large cap portfolio }\end{array} \\ \text { HML } \quad=\quad \begin{array}{l}\text { the difference in return between a portfolio of high } \\ \text { book-to-market stocks and a portfolio of low book-to-market } \\ \text { stocks } \\ \text { the difference in return between a portfolio of past winners and } \\ \text { a portfolio of past losers }\end{array}\end{array}$

Table 5.4 reports summary statistics on the factor portfolios we use for each country. Note that the premium on the SMB factor is negative in each country, indicating that small stocks suffered during the period examined. The momentum portfolio provides an interesting result, momentum strategies only add value in three out of five countries. Where especially in Italy and the United Kingdom momentum strategies offer huge returns, in France and Germany they seem to be absent or rather contrarian oriented. This is contrary to Rouwenhorst (1998) who documents positive momentum returns for all European countries. The fact that we consider a different sample period, 1991-1998 as opposed to Rouwenhorst who uses the 19801995 period, can partly explain this difference. Furthermore his sample covers MSCI stocks only, which are biased to the larger firms in each market. Because of the negative correlation between our SMB and PR6m factors (see table 5.4) it could be that stock price momentum is more pervasive amongst large stocks than small stocks, at least during the 1991-1998 period. The low cross-correlations in table 5.4 suggest that multicollinearity does not substantially affect the estimated factor loadings. Results not reported in the table provide strong evidence for our 4-factor model as opposed to the single index model. For about $85 \%$ of the funds in the sample we reject the hypothesis that the SMB, HML and Pr6m factor are jointly 0 at the $5 \%$ level. Which is in line with our US findings in chapter 4 . The remaining $15 \%$ of funds mainly concerns index funds, for which it is self-evident that the market index should be the sole benchmark to use. 


\subsubsection{Results}

Table 5.5 reports the results for the 4-factor model. For each country we form equally weighted portfolios containing all funds within a particular investment style. In addition we construct a portfolio consisting of all funds within a particular country (all funds). Because this only provides an aggregate picture of mutual fund performance we also estimate equation (5.2) for each fund individually. The last column of table 5.5 presents the distribution of individually estimated $\alpha$ 's per investment style. We report the percentage of significantly positive $\alpha$ 's (+), significantly negative $\alpha$ 's (-) and $\alpha$ 's which are insignificantly different from zero $(0)$.

A first glance at the factor loadings reveals significant positive SMB loadings for the majority of funds, indicating the returns of funds being driven relatively more by smaller stocks. The HML factor seems to add a little bit less explanatory power, as only half of the style loadings are significant (at the $5 \%$ level). On average funds seem to follow a more value oriented style. The fourth factor, Pr6m, also shows up significantly in about half of the cases, while the sign of the coefficients is mostly negative, indicating contrarian strategies.

At first these results provide some understanding of the preferences of mutual fund managers as revealed by their portfolio holdings. European mutual funds seem to prefer smaller stocks and stocks with high book-to-market ratios (value). ${ }^{40}$ Carhart (1997) and Gruber (1996) examine US fund preferences and report funds prefer smaller stocks and stocks with low book-to-market ratios (growth). ${ }^{41}$ Lakonishok, Shleifer \& Vishny (1994) argue the latter is due to agency problems within institutions. Because Carhart's and Gruber's sample respectively ended in 1993 and 1994 they possibly did not pick up the influence of the Fama \& French (1992) study, which demonstrated that high book-to-market stocks produce higher risk-adjusted returns than low book-to-market stocks do. As our sample ends in 1998, the value preference of most European funds seems relevant, based on the 1992 findings by Fama \& French. Finally it seems European mutual funds are not employing simple momentum strategies like we have seen for US funds in Carhart (1997). The results are somewhat mixed as they suggest that European funds are both contrarian and momentum oriented. Because we investigate European mutual fund performance we will now focus on 4-factor alphas. On an aggregate country level (all funds portfolio) we observe negative alphas for Germany, where all other countries produce positive alphas. Significant out-performance however can only be found with UK funds. If we take a closer look at investment style level we find that small cap funds deliver significant out-performance in 3 out of 4 countries. The individual results in the last column confirm this result as $28 \%$ of all small cap alphas are significantly positive (at the

\footnotetext{
${ }^{40}$ Except for France.

${ }^{41}$ Falkenstein (1996) also analyzes fund preferences and concludes funds prefer large value stocks. His sample period however covers only 2 years of portfolio holdings, 1991 through 1992.
} 
Table 5.5: Summary Statistics for the Carhart 4-factor model for the period 1991 - 1998

\begin{tabular}{|c|c|c|c|c|c|c|c|c|}
\hline & $\alpha$ & $\mathbf{M}$ & SMB & HML & Pr6m & $\mathbf{R}_{\text {adj }}^{2}$ & $\begin{array}{l}\text { No } \\
\text { funds }\end{array}$ & $\begin{array}{c}\alpha \text { distribution } \\
+/ 0 /-\end{array}$ \\
\hline \multicolumn{9}{|l|}{ France } \\
\hline Growth & 0.36 & $0.87^{\circ \cdots}$ & 0.00 & $-0.09^{* \cdots}$ & -0.02 & 0.95 & 55 & $2 / 94 / 4$ \\
\hline Index & -1.68 & $1.03^{\cdots *}$ & $-0.21^{\cdots *}$ & $-0.06^{\circ}$ & $-0.10^{* *}$ & 0.97 & 20 & $0 / 75 / 25$ \\
\hline Small companies & $2.28^{\circ}$ & $0.78^{* *}$ & $0.50^{\cdots *}$ & -0.01 & $0.15^{\cdots *}$ & 0.91 & 24 & $33 / 63 / 4$ \\
\hline All funds & 0.22 & $0.89^{* *}$ & $0.06{ }^{* *}$ & $-0.07^{* \ldots}$ & 0.01 & 0.97 & 99 & \\
\hline \multicolumn{9}{|l|}{ Germany } \\
\hline General & -1.32 & $1.05^{* *}$ & -0.01 & 0.04 & $0.08^{* *}$ & 0.96 & 45 & $2 / 84 / 14$ \\
\hline Growth & -1.68 & $1.12^{\cdots}$ & 0.00 & $0.07^{\circ}$ & $0.11^{\circ *}$ & 0.95 & 5 & $0 / 100 / 0$ \\
\hline Income & -2.40 & $1.04^{\circ *}$ & -0.03 & 0.05 & $0.08^{\circ *}$ & 0.95 & 2 & $0 / 50 / 50$ \\
\hline Small companies & 0.56 & $1.21 \cdots$ & $0.91^{\cdots}$ & $-0.09^{\circ}$ & -0.03 & 0.89 & 5 & $40 / 60 / 0$ \\
\hline All funds & -1.20 & $1.07^{* *}$ & 0.06 & 0.03 & $0.07^{* *}$ & 0.97 & 57 & \\
\hline \multicolumn{9}{|l|}{ Italy } \\
\hline Italian equity & 0.72 & $0.67^{\circ . *}$ & $0.07^{\circ}$ & $0.10^{\circ *}$ & $0.06^{* 0}$ & 0.95 & 21 & $5 / 95 / 0$ \\
\hline Italian specialist & 1.20 & $0.77^{* . *}$ & 0.04 & $0.12^{\cdots *}$ & $0.11 \cdots$ & 0.95 & 16 & $0 / 94 / 6$ \\
\hline All funds & 0.84 & $0.71^{\ldots}$ & 0.06 & $0.10^{* . *}$ & 0.08 & 0.95 & 37 & \\
\hline \multicolumn{9}{|l|}{ Netherlands } \\
\hline Growth & 1.80 & $0.95^{\circ \cdot *}$ & $0.18^{\cdots \cdot}$ & $0.09^{* * *}$ & 0.01 & 0.94 & 5 & $0 / 100 / 0$ \\
\hline Index & 1.20 & $1.06 \%$ & $0.14^{\cdots *}$ & $0.11^{\cdots}$ & -0.04 & 0.94 & 3 & $0 / 100 / 0$ \\
\hline Small companies & $3.96^{\circ}$ & $0.84^{\circ . *}$ & $0.80^{* *}$ & 0.00 & -0.06 & 0.76 & 1 & $0 / 100 / 0$ \\
\hline All funds & 1.80 & $0.95^{\ldots \ldots *}$ & $0.24^{\ldots \ldots}$ & $0.08^{* * *}$ & -0.01 & 0.95 & 9 & \\
\hline \multicolumn{9}{|l|}{ United Kingdom } \\
\hline Growth/Income & 0.84 & $0.95 \cdots$ & $0.07^{\cdots . *}$ & $0.08 \cdots$ & $-0.05^{\circ}$ & 0.97 & 79 & $9 / 87 / 4$ \\
\hline Income & 1.56 & $0.92^{\cdots \cdots}$ & $0.15^{\cdots}$ & $0.14^{\cdots}$ & $-0.05^{\circ}$ & 0.96 & 72 & $19 / 77 / 4$ \\
\hline Growth & $1.32^{\circ}$ & $0.98 \ldots$ & $0.22 \cdots$ & 0.00 & $-0.06^{\circ}$ & 0.98 & 102 & $16 / 79 / 5$ \\
\hline Small companies & $2.04^{* *}$ & $0.87^{\cdots}$ & $0.98^{* *}$ & $-0.11^{\cdots *}$ & $0.05^{\circ}$ & 0.97 & 51 & $25 / 73 / 2$ \\
\hline All funds & $1.33^{* *}$ & $0.94^{\ldots * *}$ & $0.29^{\cdots *}$ & $0.04^{* *}$ & $-0.04^{\circ}$ & 0.98 & 304 & \\
\hline
\end{tabular}

Notes: The table reports the results of the estimation of equation (5.2) for the period between 1991 and 1998 . Reported are the OLS estimates for equally weighted portfolios per investment style.

$$
R_{1}-R f_{1}=\alpha+\beta_{0}\left(R m_{4}-R f_{6}\right)+\beta_{1} S M B_{1}+\beta_{2} H L_{4}+\beta_{3} P R 6 m_{1}+\varepsilon_{i t}
$$

Where $R_{1}$ is the fund return, $R f_{1}$ the risk-free rate, $R m$ the return on the total Universe according to Worldscope. and SMB and HML. the factor-mimicking portfolios for size and book-to-market. Prom is a factor-mimicking portfolio for the 6-month return momentum. All alphas in the table are annualized. The last column gives the distribution of individually estimated $\alpha$ 's for all funds in a specific investment style. Reported are the $\%$ of significantly positive $\alpha$ 's $(+)$, significantly negative $\alpha$ 's $(-)$ and $\alpha$ 's which are insignificantly different from zero $(0)$, at the $5 \%$ level. "All funds" is an equally weighted portfolio of all mutual funds within a specific country. T. stats are heteroskedasticity consistent. "Significant at the $1 \%$ level ${ }^{~ "}$ Significant at the $5 \%$ level ${ }^{\circ}$ Significant at the $10 \%$ level 
$5 \%$ level). So even after adjusting for size, book-to-market and short-term return momentum small cap funds seem to add value. ${ }^{42}$

Finally the percentage of significantly positive alphas is rather high for UK funds. This may be driven by the negative exposure of most funds to the momentum portfolio, which yielded over $11 \%$ a year. In paragraph 5.4 .3 we will explore this possibility further. All other investment styles perform as we would expect them to do, with alphas insignificantly different from zero.

\subsubsection{Robustness of the Results}

The results observed before could be influenced by a missing factor in our analysis. Elton, Gruber, Das \& Hlavka (1993) for instance propose the inclusion of a bond index in mutual fund performance assessment. They argue that some funds invest in higher yielding and risky bonds, which is not picked up by the risk-free rate (Rf). If corrected for the impact of bonds on mutual fund returns, they find this lowers risk-adjusted performance (alpha) for all mutual funds.

We test for this possible bias in our analysis by introducing the excess return on a local Government bond index in equation (5.2), which now consists of 5 factors. We find that European mutual funds are only to a small extent exposed to bond returns. While most bond betas are between -0.03 and 0.06 , none of examined fund categories (on country and style level) produce significant loadings on the bond index..$^{43}$ More importantly the observed alpha estimates do not change significantly if we include a bond index. Therefore we think the exclusion of a bond index does not influence the conclusions to be drawn from our 4 factormodel.

Instead of a missing factor another possibility could be over-specification of our model. While the Fama-French factors SMB and HML are both based on actual investment strategies, the momentum factor is not that clearly defined in asset management. Morningstar for instance only uses size and book-to-market to identify mutual fund styles. Moreover, empirical work by Elton, Gruber \& Blake (1999) documented only weak support for a momentum factor, if compared to adding a mutual fund growth factor (MGO).

To consider the influence of the momentum factor we repeat our performance analysis using the Fama-French 3-factor model, so excluding the momentum variable. In table 5.6 we compare the results using both the 3 and 4-factor model. Using the 3 -factor model the performance (alpha) of Germany and the United Kingdom decreases, of Italy and the Netherlands improves, while finally French fund performance seems unaffected. The two biggest changes occur with Italian and UK funds. This can be explained as follows; Italian

\footnotetext{
${ }^{42}$ An F-test to examine whether all small cap alphas (for 4 countries) jointly are equal to zero is rejected at the $5 \%$ level.

${ }^{43}$ Results are available upon request with the authors.
} 
funds exhibit a positive 4-factor loading on the momentum factor (see table 5.5) while the return of this momentum portfolio is quite high (see table 5.4). Dropping the momentum factor therefore increases alpha c.p. UK funds on the other hand produce a negative loading on the momentum factor (see table 5.5) while the return on the momentum portfolio is also quite high (see table 5.4). Deleting the momentum factor drives their alpha down c.p. This causes the significance of overall UK out-performance to drop to the $10 \%$ level, instead of the $5 \%$ level before.

The question remains which model is better able to explain European mutual fund performance. To examine this we turn to the $\mathrm{R}_{\text {adj }}^{2}$ of both the 3 and 4 -factor model. From table 5.6 we learn that the $\mathrm{R}_{\text {adj }}^{2}$ of the 3 -factor model is equal to or lower than the $\mathrm{R}^{2}$ adj of the 4-factor model in all cases. In addition to this we report loglikelihoods of both models, which enable us to perform a standard LR test (see table 5.6, last column). This confirms the results of examining the differences in $\mathrm{R}^{2}$ adj. All loglikelihoods of the 3-factor model are lower, and in even 8 out of 21 cases significantly lower than the ones obtained from the 4 -factor model.

Based on the influence on alpha and fit, we do not think our main conclusion until now, out-performance of small cap funds, is driven by the inclusion of the Carhart (1997) momentum factor. Therefore the remaining analyses, unless stated otherwise, are based on 4factor results. $^{44}$

Based on the results from chapter 4 we now test for the influence of time-varying risks on performance measurement. Consider the following case were $\mathbf{Z}_{1 \cdot 1}$ is a vector of lagged predetermined instruments. Assuming that the beta for a fund varies over time, and that this variation can be captured by a linear relation to the conditional instruments, then $\beta_{\mathrm{it}}=\beta_{\mathrm{i} 0}+\mathbf{B}_{\mathrm{i}}^{\prime}$ $\mathbf{Z}_{\uparrow-1}$, where $\mathbf{B}_{i}^{\prime}$ is a vector of response coefficients of the conditional beta with respect to the instruments in $\mathbf{Z}_{1-1}$. For a single index model the equation to be estimated then becomes

$$
R_{i t}-R f_{t}=\alpha_{i}+\beta_{i 0}\left(R m_{t}-R f_{i}\right)+B_{i}^{\prime} Z_{i-1}\left(R m_{t}-R f_{t}\right)+\varepsilon_{i t}
$$

This equation can easily be extended to incorporate multiple factors, which results in a conditional Carhart 4-factor model with time-varying betas. The instruments we use are (1) the 1-month T-bill rate, (2) dividend yield on the market index, (3) the slope of the term structure and finally (4) the quality spread, by comparing the yield of government and corporate bonds. All instruments are lagged 1 month and collected for each country separately.

\footnotetext{
${ }^{44}$ All 3-factor results are however available upon request from the authors.
} 
Table 5.6: Results Carhart 4-factor versus Fama-French 3-factor model

\begin{tabular}{|c|c|c|c|c|c|c|}
\hline & $\begin{array}{r}\text { Carhart } \\
\text { 4-factor } \\
\text { alpha } \\
\end{array}$ & $\mathbf{R}_{\text {adj }}^{2}$ & $\log L$ & $\begin{array}{c}\text { FF } \\
\text { 3-factor } \\
\text { alpha }\end{array}$ & $\mathbf{R}_{\text {adj }}^{2}$ & $\log L$ \\
\hline \multicolumn{7}{|l|}{ France } \\
\hline Growth & 0.36 & 0.95 & -101.00 & 0.37 & 0.95 & -101.17 \\
\hline Index & -1.68 & 0.97 & -105.61 & -1.41 & 0.96 & $-108.43^{\prime \prime}$ \\
\hline Small companies & $2.28^{\circ}$ & 0.91 & -123.74 & 1.95 & 0.89 & $-127.00^{\prime \prime}$ \\
\hline All funds & 0.22 & 0.97 & -88.63 & 0.23 & 0.96 & -88.67 \\
\hline \multicolumn{7}{|l|}{ Germany } \\
\hline General & -1.32 & 0.96 & -125.61 & -1.40 & 0.96 & $-127.65^{\prime \prime}$ \\
\hline Growth & -1.68 & 0.95 & -144.33 & -1.85 & 0.95 & $-147.37^{\prime \prime}$ \\
\hline Income & -2.40 & 0.95 & -163.11 & $-2.96^{\circ}$ & 0.92 & -163.38 \\
\hline Small companies & 0.56 & 0.89 & -168.73 & 0.42 & 0.89 & -168.81 \\
\hline All funds & -1.20 & 0.97 & -122.98 & -1.32 & 0.96 & -124.74 \\
\hline \multicolumn{7}{|l|}{ Italy } \\
\hline Italian equity & 0.72 & 0.95 & -151.55 & 1.45 & 0.94 & $-153.48^{\prime \prime}$ \\
\hline Italian specialist & 1.20 & 0.95 & -161.72 & 2.42 & 0.94 & $-166.76^{\prime \prime}$ \\
\hline All funds & 0.84 & 0.95 & -154.77 & 1.81 & 0.94 & $-157.88^{\prime \prime}$ \\
\hline \multicolumn{7}{|l|}{ Netherlands } \\
\hline Growth & 1.80 & 0.94 & -138.26 & 1.90 & 0.94 & -138.32 \\
\hline Index & 1.20 & 0.94 & -153.96 & 0.88 & 0.94 & -154.46 \\
\hline Small companies & $3.96^{\circ}$ & 0.76 & -187.42 & $3.44^{\circ}$ & 0.75 & -187.69 \\
\hline All funds & 1.80 & 0.95 & -133.54 & $2.02^{\circ}$ & 0.95 & -133.65 \\
\hline \multicolumn{7}{|l|}{ United Kingdom } \\
\hline Growth/Income & 0.84 & 0.97 & -86.16 & 0.35 & 0.97 & -87.69 \\
\hline Income & 1.56 & 0.96 & -102.84 & 1.00 & 0.96 & -103.97 \\
\hline Growth & $1.32^{\circ}$ & 0.98 & -80.35 & 0.67 & 0.97 & $-83.15^{\prime \prime}$ \\
\hline Small companies & $2.04^{\circ}$ & 0.97 & -91.76 & $2.55^{\cdots *}$ & 0.97 & -93.13 \\
\hline All funds & $1.33^{* *}$ & 0.98 & -71.62 & $0.93^{\circ}$ & 0.98 & -73.00 \\
\hline \multicolumn{7}{|c|}{ 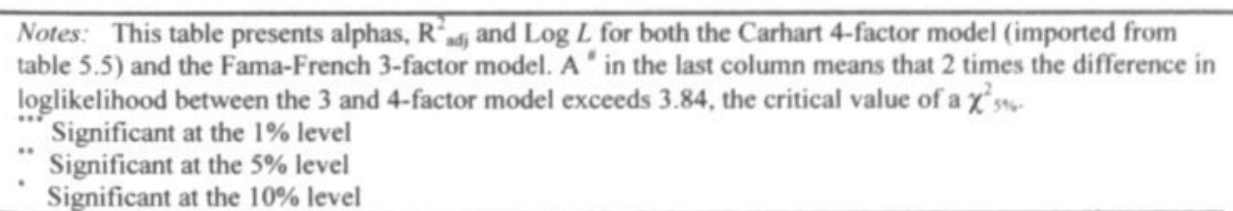 } \\
\hline
\end{tabular}


Table 5.7 presents the results of the conditional Carhart 4-factor model for the individual countries. While column 2 repeats the unconditional alphas from table 5.5 , the conditional alphas are in column 4 . In over $2 / 3$ of the cases the hypothesis of constant betas can be rejected at the $5 \%$ level (see Wald test statistics in column 6 ), indicating strong time-variation in betas. The estimated conditional alphas however do not differ that much from the unconditional ones. On average they increase and make several investment style portfolios significant out-performers. From this we conclude that our results are not driven by timevariation in betas. Nevertheless from now on we report results on subsequent tests for both unconditional and conditional models, as it seems the conditional model adds sufficiently explanatory power in most cases.

As a final robustness check we consider the influence our fund-weighting scheme exerts on the results observed in section 5.4.2. For that reason we construct portfolios of funds based on individual asset size and examine 4-factor alphas. From results not reported in this chapter it appears that on average fund alphas rise by about $0.4 \%$ a year if capitalization weighted portfolios are used instead of equally weighted portfolios. ${ }^{45}$ We therefore think the use of equally weighted portfolios does not severely influence the earlier results, as cap weighting only strengthens our results.

\subsubsection{Management Fees}

Until now we have only considered mutual fund returns net of costs. This means management fees were already deducted from the fund's return. ${ }^{46}$ From US evidence we know that most mutual funds are quite able to follow the market, with alphas insignificantly different from zero. If however management fees are deducted funds under-perform the market by the amount of fees they charge the investor. To examine the influence of fees on European mutual fund performance we first present average country alphas (after costs) for both the unconditional and conditional model. From table 5.8 column 2 we learn that most funds perform as we would expect them to do, with alphas insignificantly different from zero. The only exception to this are UK funds, which out-perform significantly using both models.

\footnotetext{
${ }^{45}$ Results are available upon request from the authors.

${ }^{46}$ Loads however are not considered.
} 
Table 5.7: Unconditional versus Conditional performance evaluation

\begin{tabular}{|c|c|c|c|c|c|}
\hline & $\begin{array}{l}\text { Unconditional } \\
\text { alpha }\end{array}$ & $\mathbf{R}_{\text {adj }}^{2}$ & $\begin{array}{c}\text { Conditional } \\
\text { alpha }\end{array}$ & $\mathbf{R}_{\text {adj }}^{2}$ & $\begin{array}{l}\text { Wald } \\
\text { (p-value) }\end{array}$ \\
\hline \multicolumn{6}{|l|}{ France } \\
\hline Growth & 0.36 & 0.95 & 0.81 & 0.96 & 0.027 \\
\hline Index & -1.68 & 0.97 & -1.95 & 0.96 & 0.904 \\
\hline Small companies & $2.28^{\circ}$ & 0.91 & $3.74^{* *}$ & 0.93 & 0.003 \\
\hline All funds & 0.22 & 0.97 & 0.80 & 0.97 & 0.001 \\
\hline \multicolumn{6}{|l|}{ Germany } \\
\hline General & -1.32 & 0.96 & -2.15 & 0.97 & 0.022 \\
\hline Growth & -1.68 & 0.95 & -2.68 & 0.96 & 0.074 \\
\hline Income & -2.40 & 0.95 & -2.98 & 0.94 & 0.001 \\
\hline Small companies & 0.56 & 0.89 & 0.18 & 0.91 & 0.007 \\
\hline All funds & -1.20 & 0.97 & -2.17 & 0.97 & 0.028 \\
\hline \multicolumn{6}{|l|}{ Italy } \\
\hline Italian equity & 0.72 & 0.95 & 0.51 & 0.96 & 0.000 \\
\hline Italian specialist & 1.20 & 0.95 & 0.90 & 0.97 & 0.000 \\
\hline All funds & 0.84 & 0.95 & 0.43 & 0.97 & 0.000 \\
\hline \multicolumn{6}{|l|}{ Netherlands } \\
\hline Growth & 1.80 & 0.94 & $2.74^{\circ *}$ & 0.96 & 0.000 \\
\hline Index & 1.20 & 0.94 & 1.35 & 0.94 & 0.303 \\
\hline Small companies & $3.96^{\circ}$ & 0.76 & $6.49^{\circ *}$ & 0.80 & 0.011 \\
\hline All funds & 1.80 & 0.95 & $3.08^{* *}$ & 0.96 & 0.006 \\
\hline \multicolumn{6}{|l|}{ United Kingdom } \\
\hline Growth/Income & 0.84 & 0.97 & 0.73 & 0.98 & 0.062 \\
\hline Income & 1.56 & 0.96 & 1.51 & 0.97 & 0.012 \\
\hline Growth & $1.32^{\circ}$ & 0.98 & 1.04 & 0.98 & 0.253 \\
\hline Small companies & $2.04^{\circ *}$ & 0.97 & $2.96^{\circ *}$ & 0.97 & 0.275 \\
\hline All funds & $1.33^{* *}$ & 0.98 & $1.40^{* *}$ & 0.98 & 0.080 \\
\hline \multicolumn{6}{|c|}{$\begin{array}{l}\text { Notes: This table presents the results from the unconditional (column } 2 \text { and } 3 \text { ) and conditional } \\
\text { (column } 4 \text { and } 5 \text { ) performance model. The results from the unconditional model are imported from } \\
\text { table } 5.6 \text { column 2, the conditional model results stem from the multifactor version of equation ( } 5.3 \text {. } \\
\text { Here we allow the market, SMB, HML and PR6m betas to vary over time as a function of (1) the I } \\
\text { month T-bill rate, (2) dividend yield (3) the slope of the term structure and (4) the quality spread. The } \\
\text { last column of table } 5.7 \text { provides results for heteroskedasticity-consistent Wald tests to examine } \\
\text { whether the conditioning information adds marginal explanatory power to the unconditional model. } \\
\text { All alphas are annualized. } \\
\text { - Significant at the } 1 \% \text { level } \\
\text { Significant at the } 5 \% \text { level } \\
\text { Significant at the } 10 \% \text { level }\end{array}$} \\
\hline
\end{tabular}


If we now add back management fees (observable from table 5.3) to fund returns and repeat our analysis, column 3 appears. This column reports average country alphas before costs are deducted. Most funds now exhibit positive alphas on the models that are adapted. Only German funds still under-perform, though insignificantly. The number of significantly outperforming countries increases. UK and Italian funds out-perform at the $5 \%$ level and French and Dutch funds at the $10 \%$ level, using the unconditional Carhart 4-factor model. Based on conditional model results even 4 out of 5 countries out-perform at the $5 \%$ level. This suggests that European funds (in contrast to US funds) are sufficiently successful in finding and implementing new information to offset their expenses, and therefore add value for the investor.

Table 5.8: Performance after and before management fees are deducted

\begin{tabular}{|c|c|c|}
\hline Country & $\begin{array}{c}\text { After fees } \\
\text { alpha }\end{array}$ & $\begin{array}{c}\text { Before fees } \\
\text { alpha }\end{array}$ \\
\hline \multicolumn{3}{|l|}{ France } \\
\hline unconditional & 0.22 & $1.40^{\circ}$ \\
\hline conditional & 0.80 & $2.04^{\circ *}$ \\
\hline \multicolumn{3}{|l|}{ Germany } \\
\hline unconditional & -1.20 & -0.36 \\
\hline conditional & -2.17 & -1.32 \\
\hline \multicolumn{3}{|l|}{ Italy } \\
\hline unconditional & 0.84 & $2.88^{\circ *}$ \\
\hline conditional & 0.43 & $2.32^{\circ *}$ \\
\hline \multicolumn{3}{|l|}{ Netherlands } \\
\hline unconditional & 1.80 & $2.64^{\circ}$ \\
\hline conditional & $3.08^{\circ *}$ & $3.59^{\circ \cdots}$ \\
\hline \multicolumn{3}{|l|}{ United Kingdom } \\
\hline unconditional & $1.33^{\circ *}$ & $2.56^{\circ * *}$ \\
\hline conditional & $1.40^{\circ}$ & $2.59^{* *}$ \\
\hline \multicolumn{3}{|c|}{$\begin{array}{l}\text { Notes: This table gives both unconditional and conditional } \\
\text { average country alphas after costs are deducted (column 2) and } \\
\text { before (column } 3 \text { ) costs are deducted from fund returns. All } \\
\text { alphas are annualized. } \\
\text { - Significant at the } 1 \% \text { level } \\
\text { - Significant at the } 5 \% \text { level } \\
\text { Significant at the } 10 \% \text { level }\end{array}$} \\
\hline
\end{tabular}

\subsection{Persistence}

The hypothesis that mutual funds with an above average return in this period will also have an above average return in the next period is called the hypothesis of persistence in performance. This topic has been well documented in the finance literature. Hendricks, Patel \& Zeckhauser (1993) and Brown \& Goetzmann (1995) find evidence of persistence in mutual fund 
performance over short-term horizons where Grinblatt \& Titman (1992) and Elton, Gruber, Das \& Blake (1996) document mutual fund return predictability over longer horizons. Carhart (1997) shows that this "hot hands" effect is mainly due to persistence in expense ratios and the pursuing of momentum strategies. Contrary evidence comes from Jensen (1969), who does not find predictive power for alpha estimates. The importance of persistence analysis is stressed by Sirri and Tufano (1998) who document large money inflows into last year's top performers and extractions from last year's losers. Finally Zheng (1999) finds that this newly invested money is able to predict future fund performance, in that portfolios of funds that receive more money subsequently perform significantly better than those that lose money.

To investigate whether persistence in mutual fund performance is also present for European funds we rank all funds within a specific country, based on past 12-month return. Funds with the highest previous 12-month return (selection period) go into portfolio 1 and funds with the lowest past 12-month return go into portfolio 3 (Germany and Italy), 4 (France) or 10 (UK). ${ }^{47}$ For France and the UK the high and low portfolios are further subdivided on the same measure, for added detail. These equally weighted portfolios are then held for 1 year (performance period) before we rebalance them again, based on their last 12 month return. This is continued throughout the sample period until we get a time series of monthly returns on these portfolios. Funds that disappear during the year are included until they disappear, after which portfolio weights are re-adjusted accordingly.

Table 5.9 reports the result of this exercise in column two, were excess returns on the rank portfolios are given. For all examined countries we observe a monotonically decreasing excess return if we move from the high- to the low- past performance portfolio. The average spread between the high- and low -portfolios ranges from $0.83 \%$ per year for France to $6.08 \%$ per year for the UK. The only significant spread however is exhibited by UK funds. A cause for this weak persistence for France, Germany and Italy could be the rather small number of funds in the sample, respectively 99,57 and 37 . This makes it much harder to detect a persistent pattern using only 3 or 4 portfolios. That is probably why the UK, with over 300 funds, does allow us to infer significant conclusions from this persistence analysis.

Because it could be argued that the funds in portfolio 1 receive higher returns because they take on more risk, we then use the unconditional Carhart (1997) 4-factor model to control for several risk factors. Columns four through nine (table 5.9) report the results of this analysis.

\footnotetext{
${ }^{47}$ Because we only have 9 Dutch funds in our sample we do not examine Dutch mutual fund persistence.
} 
Table 5.9: Mutual fund persistence based on 12-month lagged return, 4-factor model

\begin{tabular}{|c|c|c|c|c|c|c|c|c|c|c|c|}
\hline \multicolumn{3}{|l|}{ France } & \multicolumn{6}{|c|}{ Unconditional 4-factor model } & \multicolumn{2}{|c|}{ Conditional $4 \mathrm{f}$} & \multirow{2}{*}{$\begin{array}{l}\text { Wald } \\
\text { P-value }\end{array}$} \\
\hline Portfolio & $\begin{array}{l}\text { Excess } \\
\text { return }\end{array}$ & Stdev & Alpha & Market & SMB & HML & PR6m & $\overline{R^{2}}{ }_{\text {adj }}$ & Alpha & $\overline{\mathrm{R}^{2}}{ }_{\Delta \mathrm{dj}}$ & \\
\hline IA & 4.65 & 13.36 & 1.77 & $0.87 \ldots$ & $0.26 \ldots$ & -0.03 & $0.08^{\circ}$ & 0.90 & 1.87 & 0.92 & 0.067 \\
\hline IB & & 13.42 & & & $0.16 \ldots$ & & 0.0 & & & 0.95 & 0.250 \\
\hline I (high) & 3.8 & 13.31 & 0.91 & $88 \ldots$ & $0.21^{\cdots \cdots}$ & -0.03. & 0.06 & & 1.2 & 0.94 & 0.129 \\
\hline 2 & & 14.15 & & $0.91^{\ldots \ldots . . .}$ & 0.00 & $-0.08 \cdots$ & -0.05. & 0.96 & -1.0 & 0.96 & 0.559 \\
\hline 3 & 3.79 & 14.55 & 0.25 & $0.92 \cdots$ & -0.05 & $-0.11 \cdots$ & $-0.11_{.}^{*}$ & 0.96 & 0.21 & 0.96 & 0.072 \\
\hline 4 (low) & & & & $0.90^{\circ \cdots}$ & 0.0 & -0.1 & $-0.14^{* *}$ & 0.9 & 2.3 & 0.93 & 0.083 \\
\hline $4 \mathrm{~A}$ & 3.29 & 14.77 & -0.44 & $0.92 \cdots$ & -0.02 & $-0.14 *$ & $-0.15^{* *}$ & 0.92 & 1.39 & 0.93 & 0.176 \\
\hline $4 \mathrm{~B}$ & 3.8 & 14.1 & & & 0.04 & $-0.11^{\circ *}$ & $-0.12^{* *}$ & 0.90 & 3.32 & 0.92 & 0.041 \\
\hline & & & 0.94 & & 0.20 & $0.10^{\circ}$ & $0.19^{\prime \prime}$ & 0.11 & -1.13 & 0.26 & 0.053 \\
\hline 1A-4B spread & 0.83 & 7.30 & 1.38 & -0.01 & $0.22{ }^{*}$ & 0.09 & $0.211^{*}$ & 0.07 & -1.45 & 0.27 & 0.024 \\
\hline
\end{tabular}

\begin{tabular}{|c|c|c|c|c|c|c|c|c|c|c|c|}
\hline \multicolumn{3}{|l|}{ Germany } & \multicolumn{6}{|c|}{ Unconditional 4-factor model } & \multicolumn{2}{|c|}{ Conditional $4 \mathrm{f}$} & \multirow{2}{*}{$\begin{array}{l}\text { Wald } \\
\text { P-value }\end{array}$} \\
\hline Portfolio & $\begin{array}{l}\text { Excess } \\
\text { return }\end{array}$ & Stdev & Alpha & Market & $\overline{\text { SMB }}$ & HML & PR6m & $\mathrm{R}^{2}$ asj & Alpha & $\overline{\mathrm{R}^{2}}$ & \\
\hline 1 (high) & 8.76 & 17.21 & -0.89 & $1.07 \mathrm{~m}$ & 0.01 & $0.07^{\circ}$ & 0.08 & 0.96 & -1.69 & 0.97 & 0.012 \\
\hline 2 & 8.43 & 17.17 & -1.33 & $1.04 \cdots$ & -0.06 & 0.02 & 0.04 & 0.96 & -2.17 & 0.96 & 0.020 \\
\hline 3 (low) & 7.23 & 16.31 & -1.61 & $1.06 \cdots$ & 0.08 & 0.02 & -0.01 & 0.97 & -2.85 & 0.97 & 0.015 \\
\hline 1.3 spread & 1.53 & 2.93 & 0.71 & 0.01 & -0.07 & 0.05 & $0.09^{\prime \prime}$ & 0.15 & 1.16 & 0.23 & 0.018 \\
\hline
\end{tabular}

\begin{tabular}{|c|c|c|c|c|c|c|c|c|c|c|c|}
\hline \multicolumn{3}{|l|}{ Italy } & \multicolumn{6}{|c|}{ Unconditional 4-factor model } & \multicolumn{2}{|c|}{ Conditional $4 \mathrm{f}$} & \multirow{2}{*}{$\begin{array}{l}\text { Wald } \\
\text { P-value }\end{array}$} \\
\hline Portfolio & $\begin{array}{l}\text { Excess } \\
\text { return }\end{array}$ & Stdev & Alpha & Market & SMB & HML & PR6m & $\overline{R_{a d j}^{2}}$ & Alpha & $\mathrm{R}_{\text {adj }}^{2}$ & \\
\hline I (high) & 8.51 & 19.77 & 1.56 & $0.72 \mathrm{~m}$ & $0.08^{\circ}$ & $0.12^{\prime \prime}$ & $0.14^{m}$ & 0.93 & 0.45 & 0.96 & 0.000 \\
\hline 2 & 7.01 & 19.75 & 1.08 & $0.73 \cdots$ & 0.06 & 0.10 & $0.06^{\circ}$ & 0.94 & -0.83 & 0.96 & 0.000 \\
\hline 3 (low) & 4.78 & 19.12 & -0.36 & $0.71^{\cdots *}$ & 0.00 & $0.09^{* *}$ & -0.01 & 0.96 & -0.74 & 0.96 & 0.048 \\
\hline 1-3 spread & $3.73^{\circ}$ & 4.78 & 1.92 & 0.01 & $0.08^{\circ}$ & 0.03 & $0.15^{\mathrm{m}}$ & 0.18 & 1.19 & 0.61 & 0.006 \\
\hline
\end{tabular}

\begin{tabular}{|c|c|c|c|c|c|c|c|c|c|c|c|}
\hline \multicolumn{3}{|l|}{ UK } & \multicolumn{6}{|c|}{ Unconditional 4-factor model } & \multicolumn{2}{|c|}{ Conditional $4 \mathrm{f}$} & \multirow{2}{*}{\begin{tabular}{|l} 
Wald \\
P-value
\end{tabular}} \\
\hline Portfolio & $\begin{array}{l}\text { Excess } \\
\text { return }\end{array}$ & Stdev & Alpha & Market & SMB & HML & PR6m & $\mathbf{R}^{2}$ adj & Alpha & $\mathrm{R}_{\text {adj }}$ & \\
\hline IA & 9.59 & 12.83 & $6.53 \mathrm{~m}$ & $0.84 \%$ & $0.54 \cdots$ & -0.04 & -0.05 & 0.90 & $7.68^{10 .}$ & 0.92 & 0.000 \\
\hline IB & 8.34 & 12.70 & $4.48 \ldots$ & $0.87^{\cdots} \ldots$ & $0.43^{\cdots *}$ & -0.07 & -0.08 & 0.95 & $6.05 \cdots$ & 0.93 & 0.002 \\
\hline IC & 8.68 & 12.20 & $4.03 \ldots$ & $0.86 \ldots$ & $0.47^{\cdots . . .}$ & -0.06 & 0.06 & 0.93 & $4.14^{\cdots *}$ & 0.95 & 0.000 \\
\hline 1 (high) & 8.88 & 12.45 & $5.13 \ldots$ & $0.86 \ldots$ & $0.48 \ldots$ & -0.06 & -0.02 & 0.96 & $5.94 \ldots$ & 0.95 & 0.000 \\
\hline 2 & 7.29 & 12.72 & $2.98^{* \ldots *}$ & $0.91^{\cdots}$ & $0.34 \ldots$ & -0.04 & $-0.07^{\circ *}$ & 0.96 & $3.42^{\cdots}$ & 0.96 & 0.046 \\
\hline 3 & 7.46 & 12.73 & $2.29 \ldots$ & $0.92 \cdots$ & $0.20^{* . *}$ & 0.01 & $-0.07^{* *}$ & 0.90 & $2.31 \cdots$ & 0.97 & 0.000 \\
\hline 4 & 7.84 & 12.75 & $2.51^{\cdots}$ & $0.93 \cdots$ & $0.19^{* * *}$ & 0.02 & $-0.06^{\circ}$ & 0.95 & $2.84^{\cdots *}$ & 0.97 & 0.063 \\
\hline 5 & 7.22 & 13.03 & 1.26 & $0.95 \ldots$ & $0.24 \ldots$ & 0.03 & -0.04 & 0.93 & $1.39^{* *}$ & 0.98 & 0.202 \\
\hline 6 & 7.30 & 13.23 & $1.74^{\circ}$ & $0.96 \cdots$ & $0.18^{* . *}$ & 0.04 & -0.06. & 0.96 & 0.94 & 0.98 & 0.135 \\
\hline 7 & 6.73 & 13.47 & 1.13 & $0.98 \ldots$ & $0.23 \ldots$ & 0.02 & $-0.05^{\circ}$ & 0.96 & 0.56 & 0.97 & 0.019 \\
\hline 8 & 6.93 & 13.61 & 0.91 & $0.99 \cdots$ & $0.27^{* *}$ & 0.04 . & 0.01 & 0.96 & 0.06 & 0.97 & 0.078 \\
\hline 9 & 5.50 & 13.24 & 0.46 & $0.94 \ldots$ & $0.35 \ldots$ & $0.07^{\circ}$ & -0.01 & 0.92 & -0.38 & 0.96 & 0.001 \\
\hline 10 (low) & 4.50 & 14.14 & -0.23 & $0.96 \ldots$ & $0.49^{\cdots \cdots}$ & $0.12^{* *}$ & 0.01 & 0.92 & -1.14 & 0.95 & 0.000 \\
\hline $10 \mathrm{~A}$ & 5.97 & 14.70 & 0.71 & $1.00^{* . *}$ & $0.42^{\ldots . . .}$ & $0.15 \cdots$ & 0.01 & 0.96 & -0.51 & 0.93 & 0.003 \\
\hline $10 B$ & 3.97 & 14.40 & -0.83 & $0.98^{* \ldots *}$ & $0.46 \ldots$ & $0.09^{\circ}$ & -0.02 & 0.92 & -0.32 & 0.94 & 0.000 \\
\hline $10 \mathrm{C}$ & 3.50 & 13.77 & -0.75 & $0.90^{* \cdots}$ & $0.58^{\cdots *}$ & $0.12^{\circ *}$ & 0.06 & 0.90 & $-2.81^{\circ *}$ & 0.93 & 0.001 \\
\hline 1-10 spread & $4.37^{\circ}$ & 6.63 & $5.36^{\prime \prime}$ & $-0.10^{\prime \prime}$ & -0.01 & $-0.18^{\prime \prime}$ & -0.04 & 0.06 & 7.08 & 0.48 & 0.000 \\
\hline 1A-10C spread & $6.08^{* *}$ & 7.20 & $7.28^{* \cdots}$ & -0.06 & -0.04 & $-0.16^{\circ}$ & -0.11 & 0.03 & $10.49^{\ldots * *}$ & 0.39 & 0.000 \\
\hline
\end{tabular}

Notes: Each year, all funds are ranked based on their previous 12-month return. The portfolios are equally weighted and weights are readjusted (monthly) whenever a fund disappears. Funds with the highest previous 12-month return go into portfolio I and funds with the lowest go into portfolio 3 (Germany and Italy), 4 (France) or 10 (UK). For France and the UK the high and low portfolios are further subdivided on the same measure. Columns 4 through 9 present the results for the unconditional model and column 10 and 11 for the conditional model. The last column provides results for heteroskedasticityconsistent Wald tests to examine whether the conditioning information adds marginal explanatory power to the unconditional model. " Significant at the $1 \%$ level " Significant at the $5 \%$ level ${ }^{*}$ Significant at the $10 \%$ level 
Controlling for market risk, book-to-market, size and stock price momentum does not consume the spread between the high and low portfolios. As before however, the only significant result is observed with UK funds, which exhibit a $7.28 \%$ spread in yearly riskadjusted returns between portfolio $1 \mathrm{~A}$ and portfolio $10 \mathrm{C}$. This is in line with for instance Blake \& Timmerman (1998) who document similar results for the UK. Columns 10 and 11 report the results for the conditional model that was derived in section 5.4.3. Conditioning on publicly available information does not alter our conclusions, France, Germany and Italy still exhibit weak or no persistence. UK funds show even stronger persistence using the conditional model. Note that the more elaborate conditional model is especially strong. compared to the unconditional model, when explaining the spread portfolios, judging from the heteroskedasticity-consistent Wald tests in the last column of table 5.9.

In paragraph 5.4.3 we considered the influence of using the 3-factor Fama-French model instead of the 4-factor Carhart model. Although the influence on alpha was moderate, our persistence analysis is potentially more sensitive to this. This can best be illustrated by looking at the UK momentum loadings for the top portfolios compared to the bottom portfolios (1a-10c: -0.11). This obviously increases alpha because of the high return on Prom $(11.49 \%)$ and could therefore induce spurious persistence. To examine this we repeat our analysis after dropping the momentum factor. These results are reported in table 5.10. From this some interesting conclusions can be drawn. First, the persistence of France and Germany remains weak. Secondly, Italian funds now exhibit strong and significant persistence using the 3 -factor model. This result however seems to be driven by time-variation in betas, as the conditional alpha is not significantly different from zero. Finally the persistence of UK funds is somewhat lowered by the exclusion of the momentum factor, but still remains strongly significant.

From this we conclude that most European funds provide only weak evidence of persistence in performance, except for UK funds. ${ }^{48}$ Buying last year's top portfolio of UK mutual funds and selling last year's bottom portfolio of funds yields a return of $6.08 \%$ per year. This spread cannot be explained by common factors or time-varying risk. ${ }^{49}$ This is contrary to Carhart (1997), who finds that half of the spread for US funds can be explained by common factors.

\footnotetext{
${ }^{43}$ We also used a 6-month rebalancing period (instead of 12 months) but found that this did not alter our findings.

${ }^{49}$ Here we do not consider the transaction costs of such a strategy, which of course lowers profits.
} 
Table 5.10: Mutual fund persistence based on 12-month lagged return, 3-factor model

\begin{tabular}{|c|c|c|c|c|c|c|c|c|c|c|}
\hline \multicolumn{3}{|l|}{ France } & \multicolumn{5}{|c|}{ Unconditional 3-factor model } & \multicolumn{2}{|c|}{ Conditional $3 \mathrm{f}$} & \multirow{2}{*}{$\begin{array}{l}\text { Wald } \\
\text { P-value }\end{array}$} \\
\hline Portfolio & $\begin{array}{l}\text { Excess } \\
\text { return }\end{array}$ & Stdev & Alpha & Market & SMB & HML & $\overline{\mathrm{R}_{\text {adj }}^{2}}$ & Alpha & $\mathbf{R}_{a d j}^{2}$ & \\
\hline IA & 4.65 & 13.36 & 1.66 & $0.86^{\mathrm{m}}$ & $0.23 \mathrm{~m}$ & -0.06 & 0.90 & 1.49 & 0.92 & 0.003 \\
\hline IB & 3.10 & 13.42 & 0.02 & $0.88^{\cdots *}$ & $0.15 \cdots$ & -0.04 & 0.95 & 0.20 & 0.96 & 0.021 \\
\hline I (high) & 3.88 & 13.31 & 0.84 & $0.87^{* \ldots *}$ & $0.19^{\cdots *}$ & -0.05 & 0.93 & 0.85 & 0.95 & 0.007 \\
\hline 2 & 3.81 & 14.15 & 0.45 & $0.92 \ldots$ & 0.02 & $-0.06 \%$ & 0.96 & -0.03 & 0.96 & 0.365 \\
\hline 3 & 3.79 & 14.55 & 0.39 & $0.94^{* \ldots .}$ & -0.01 & $-0.07^{* *}$ & 0.96 & 0.49 & 0.96 & 0.024 \\
\hline 4 (low) & 3.56 & 14.40 & 0.15 & $0.92^{\cdots \cdots}$ & 0.06 & $-0.08^{\circ}$ & 0.92 & 1.42 & 0.92 & 0.103 \\
\hline $4 \mathrm{~A}$ & 3.29 & 14.77 & -0.24 & $0.94^{\cdots . .}$ & 0.03 & $-0.09^{* *}$ & 0.92 & 0.85 & 0.92 & 0.180 \\
\hline $4 \mathrm{~B}$ & 3.83 & 14.10 & 0.54 & $0.90^{* \cdots}$ & $0.09^{* *}$ & $-0.07^{\circ}$ & 0.90 & 1.99 & 0.91 & 0.050 \\
\hline 1-4 spread & 0.32 & 6.10 & 0.70 & -0.05 & $0.13^{\mathrm{m}}$ & 0.03 & 0.11 & -0.57 & 0.25 & 0.008 \\
\hline IA-4B spread & 0.83 & 7.30 & 1.12 & -0.04 & $0.14^{* *}$ & 0.02 & 0.07 & -0.49 & 0.27 & 0.002 \\
\hline
\end{tabular}

\begin{tabular}{|c|c|c|c|c|c|c|c|c|c|c|}
\hline \multicolumn{3}{|l|}{ Germany } & \multicolumn{5}{|c|}{ Unconditional 3-factor model } & \multicolumn{2}{|c|}{ Conditional $3 \mathrm{f}$} & \multirow{2}{*}{$\begin{array}{l}\text { Wald } \\
\text {-value }\end{array}$} \\
\hline Portfolio & $\begin{array}{l}\text { Excess } \\
\text { return }\end{array}$ & Stdev & Alpha & Market & SMB & HML. & $\overline{R_{\text {adj }}^{2}}$ & Alpha & $\overline{\mathrm{R}_{\text {adf }}^{2}}$ & \\
\hline I (high) & 8.76 & 17.21 & -0.99 & $1.06 \mathrm{~m}$ & 0.04 & 0.03 & 0.96 & -1.35 & 0.97 & 0.035 \\
\hline 2 & 8.43 & 17.17 & -1.37 & $1.04^{* \cdots}$ & -0.08 & 0.00 & 0.96 & -1.74 & 0.96 & 0.033 \\
\hline 3 (low) & 7.23 & 16.31 & -1.60 & $1.06^{* *}$ & $0.09^{\circ}$ & 0.03 & 0.97 & -2.02 & 0.97 & 0.204 \\
\hline 1.3 spread & 1.53 & 2.93 & 0.61 & 0.00 & $-0.13^{\prime \prime}$ & 0.00 & 0.09 & 0.67 & 0.24 & 0.008 \\
\hline
\end{tabular}

\begin{tabular}{|c|c|c|c|c|c|c|c|c|c|c|}
\hline \multicolumn{3}{|l|}{ Italy } & \multicolumn{5}{|c|}{ Unconditional 3-factor model } & \multicolumn{2}{|c|}{ Conditional $3 \mathrm{f}$} & \multirow{2}{*}{$\begin{array}{l}\text { Wald } \\
\text { P-value }\end{array}$} \\
\hline Portfolio & $\begin{array}{l}\text { Excess } \\
\text { return }\end{array}$ & Stdev & Alpha & Market & SMB & HML & $\mathbf{R}^{2}=0$ & Alpha & $\overline{\mathrm{R}_{\text {adj }}^{2}}$ & \\
\hline I (high) & 8.51 & 19.77 & $3.53^{\circ}$ & $0.73 \mathrm{~m}$ & 0.07 & 0.06 & 0.92 & 1.11 & 0.96 & 0.000 \\
\hline 2 & 7.01 & 19.75 & 1.92 & $0.73 \cdots$ & 0.06 & $0.08^{\circ}$ & 0.93 & -0.68 & 0.96 & 0.000 \\
\hline 3 (low) & 4.78 & 19.12 & -0.52 & $0.71^{\cdots *}$ & 0.00 & $0.10^{* *}$ & 0.96 & -0.61 & 0.96 & 0.189 \\
\hline 1-3 spread & $3.73^{\circ}$ & 4.78 & $4.05^{270}$ & 0.02 & 0.07 & -0.04 & 0.02 & 1.72 & 0.48 & 0.000 \\
\hline
\end{tabular}

\begin{tabular}{|c|c|c|c|c|c|c|c|c|c|c|}
\hline \multicolumn{3}{|l|}{ UK } & \multicolumn{5}{|c|}{ Unconditional 3-factor model } & \multicolumn{2}{|c|}{ Conditional $3 \mathrm{f}$} & \multirow{2}{*}{$\begin{array}{l}\text { Wald } \\
\text { P-value }\end{array}$} \\
\hline Portfolio & $\begin{array}{l}\text { Excess } \\
\text { return }\end{array}$ & Stdev & Alpha & Market & SMB & HML & $\mathbf{R}_{\text {adj }}^{2}$ & Alpha & $\overline{R^{2} \text { adj }}$ & \\
\hline IA & 9.59 & 12.83 & $6.07^{\mathrm{m}}$ & $0.85^{\mathrm{m}}$ & $0.55^{\mathrm{me}}$ & -0.03 & 0.88 & $6.88^{\mathrm{m}}$ & 0.92 & 0.000 \\
\hline IB & 8.34 & 12.70 & $4.07^{* *}$ & $0.88^{* *}$ & $0.45^{\cdots *}$ & -0.04 & 0.91 & $5.16 \ldots$ & 0.93 & 0.000 \\
\hline ic & 8.68 & 12.20 & $4.61 \cdots$ & $0.85 \cdots$ & $0.46 \cdots$ & -0.09 & 0.93 & $3.92^{\cdots *}$ & 0.95 & 0.000 \\
\hline i (high) & 8.88 & 12.45 & $4.92^{\cdots}$ & $0.86 \cdots$ & $0.48^{\cdots}$ & -0.05 & 0.92 & $5.31 \cdots$ & 0.95 & 0.000 \\
\hline 2 & 7.29 & 12.72 & $2.26^{\circ}$ & $0.92^{\cdots *}$ & $0.36 \cdots$ & -0.01 & 0.96 & 2.96 & 0.96 & 0.004 \\
\hline 3 & 7.46 & 12.73 & $1.64^{\circ}$ & $0.93^{* * *}$ & $0.21^{\cdots}$ & 0.03 & 0.96 & $2.09^{* *}$ & 0.97 & 0.030 \\
\hline 4 & 7.84 & 12.75 & $1.95^{\circ}$ & $0.93^{\cdots}$ & 0.20 & 0.04 & 0.97 & $2.71^{\cdots}$ & 0.97 & 0.013 \\
\hline 5 & 7.22 & 13.03 & 0.87 & $0.955^{* * *}$ & $0.15^{* . *}$ & 0.04 & 0.97 & 1.23 & 0.98 & 0.244 \\
\hline 6 & 7.30 & 13.23 & 1.14 & $0.97^{* \cdots}$ & $0.20^{\ldots .}$ & 0.06 & 0.97 & 1.29 & 0.98 & 0.524 \\
\hline 7 & 6.73 & 13.47 & 0.66 & $0.99^{* *}$ & $0.24 \ldots$ & 0.04 & 0.97 & 0.78 & 0.97 & 0.026 \\
\hline 8 & 6.93 & 13.61 & 1.02 & $0.99^{* \cdots}$ & 0.26 & 0.03 & 0.96 & 0.20 & 0.97 & 0.142 \\
\hline 9 & 5.50 & 13.24 & 0.39 & $0.94^{\cdots \cdot}$ & $0.36 \cdots$ & $0.07^{\circ}$ & 0.95 & -0.12 & 0.96 & 0.001 \\
\hline 10 (low) & 4.50 & 14.14 & -0.09 & $0.96^{\ldots *}$ & $0.48^{* * *}$ & $0.12^{\circ *}$ & 0.92 & -0.86 & 0.95 & 0.000 \\
\hline $10 \mathrm{~A}$ & 5.97 & 14.70 & 0.78 & $1.00 \ldots$ & $0.42^{\cdots *}$ & $0.15^{*}$ & 0.91 & -0.30 & 0.93 & 0.000 \\
\hline $10 B$ & 3.97 & 14.40 & -1.04 & $0.98^{* \cdots}$ & 0.46 & $0.10^{\circ}$ & 0.91 & -0.55 & 0.94 & 0.000 \\
\hline $10 \mathrm{C}$ & 3.50 & 13.77 & -0.17 & $0.90^{* * *}$ & $0.57^{* \cdots}$ & $0.10^{* *}$ & 0.90 & $-1.90^{\circ}$ & 0.93 & 0.000 \\
\hline $1-10$ spread & $4.37^{\circ}$ & 6.63 & $5.01^{\prime \prime}$ & $-0.10^{\prime \prime}$ & -0.00 & $-0.17^{\prime \prime}$ & 0.07 & $6.17^{\mathrm{m}}$ & 0.48 & 0.000 \\
\hline IA-10C spread & $6.08^{* *}$ & 7.20 & $6.24 *$ & -0.05 & -0.02 & $-0.13^{\circ}$ & 0.01 & $8.78^{\ldots *}$ & 0.39 & 0.000 \\
\hline
\end{tabular}

Notes: Each year, all funds are ranked based on their previous 12 -month return. The portfolios are equally weighted and weights are readiusted (monthly) whenever a fund disappears. Funds with the highest previous 12-month return go into portfolio 1 and funds with the lowest go into portfolio 3 (Germany and Italy), 4 (France) or I0 (UK). For France and the UK the high and low portfolios are further subdivided on the same measure. Columns 4 through 9 present the results for the unconditional model and column 10 and 11 for the conditional model. The last column provides results for heteroskedasticity-consistent Wald tests to examine whether the conditioning information adds marginal explanatory power to the unconditional model.

Significant at the $1 \%$ level Significant at the $5 \%$ level ${ }^{\circ}$ Significant at the $10 \%$ level 


\subsection{The Influence of Fund Characteristics on Risk-Adjusted Performance}

In general mutual fund managers claim that expenses do not reduce performance, since investors are paying for the quality of the manager's information. So if management expenses are high one would expect returns to increase as well, relative to a low cost fund. To evaluate this claim we measure the marginal effect of expense ratios and other variables on riskadjusted performance.

Estimated is:

$$
\alpha_{i}=c_{0}+c_{1} \text { Expense ratio }_{i}+c_{2} \text { LN Assets }{ }_{i}+c_{3} L N \text { Age }_{i}+\varepsilon_{i}
$$

where

$\begin{array}{lll}\alpha_{i} & \text { conditional 4-factor alpha for fund } \mathrm{i} \\ \text { Expense ratio }_{i}= & \text { Expense ratio for fund } \mathrm{i} \text { (end 1998) } \\ \mathrm{LN} \mathrm{Assets}_{\mathrm{i}}= & \mathrm{LN} \text { of total fund assets for fund i (end 1998) } \\ \mathrm{LN} \mathrm{Age}_{\mathrm{i}} & = & \mathrm{LN} \text { of Fund i's Age in number of years (end 1998) }\end{array}$

The results in table 5.11 indicate a strong relationship between expense ratio, assets under management and to a lesser extent fund age. Contrary to what mutual fund managers often claim, the relationship between management expenses and risk-adjusted performance (alpha) is significantly negative in three out of four European countries. ${ }^{50}$ Ippolito (1989) found riskadjusted returns are unrelated to expense ratio for US funds. Elton, Gruber, Das \& Hlavka (1993) however adjust for style and then find a negative correlation between expense ratios and risk-adjusted performance. This result is confirmed by Carhart (1997). Malkiel (1995) also reports a negative relationship. If he however splits the total expense ratio up into investment advisory and non-advisory expenses, he finds the former to be positively related to risk-adjusted performance, whereas non-advisory expenses (for instance marketing costs) are negatively related.

The second fund characteristic that is used to explain risk-adjusted return is total fund assets. As all countries show a significantly positive relationship between the log of fund assets and risk-adjusted performance we suspect there are still economies of scale available in the European fund market. If we consider the size of the average European fund, \$256 million compared to $\$ 723$ million for the average US fund, it seems European funds still have to grow

\footnotetext{
${ }^{50}$ Because individual fund characteristics were not available for Italian funds we do not report results for Italy.
} 
to reach an efficient asset size. If funds however get too large diseconomies of scale become apparent, like we for instance learned from the closedown of the Fidelity Magellan fund. ${ }^{51}$

Finally the influence of fund age is considered. From the results in table 5.11 we tend to believe younger funds perform better than older funds. While all coefficients are negative, only 2 countries show a significantly negative relation between fund age and risk-adjusted performance.

Table 5.11: The influence of fund characteristics on risk-adjusted performance

\begin{tabular}{lccccc}
\hline \multicolumn{1}{c}{ Country } & Constant & Expense ratio & LN Assets & LN Age & R $^{2}{ }_{\text {adi }}$ \\
\hline France & -2.52 & -0.32 & $0.80^{* \cdots}$ & -0.64 & 0.04 \\
& $(-1.01)$ & $(-0.33)$ & $(2.68)$ & $(-0.91)$ & \\
Germany & 0.83 & $-3.19^{* *}$ & $0.32^{* *}$ & $-0.85^{* *}$ & 0.15 \\
& $(0.53)$ & $(-2.76)$ & $(2.03)$ & $(-1.99)$ & \\
Netherlands & 2.51 & $-3.05^{* *}$ & $0.50^{* *}$ & -0.01 & 0.53 \\
& $(0.80)$ & $(-2.06)$ & $(2.38)$ & $(-0.01)$ & \\
United Kingdom & $3.03 *$ & $-1.11^{* *}$ & $0.54^{* *}$ & $-1.02^{* *}$ & 0.08 \\
& $(2.12)$ & $(-2.14)$ & $(3.93)$ & $(-3.54)$ & \\
\hline
\end{tabular}

Notes: Reported are the results for the following estimation:

$$
\alpha_{i}=c_{0}+c_{1} \text { Expense ratio }{ }_{i}+c_{2} L N \text { Assets } i+c_{3} L N A g e_{i}+\varepsilon_{i}
$$

were $\alpha_{i}$ is the conditional 4-factor alpha for fund $i$, expense ratio is the funds's expense ratio (end 1998), LN Assets, is based upon total fund assets at the end of 1998 and LN Age, is a fund's Age in years. The table gives the estimated coefficients with heteroskedasticity robust t-statistics within parentheses.

Significant at the $1 \%$ level

" Significant at the $5 \%$ level

- Significant at the $10 \%$ level

\footnotetext{
${ }^{51}$ Because we use end of 1998 data on fund characteristics, it could be argued that our results suffer from selfinduced correlation. For instance if well performing funds attract positive inflows through out the sample period. these funds would show up as large funds at the end of 1998 and therefore create a positive correlation with riskadjusted performance. Of course it therefore would be preferable to use time series of fund characteristics. This however is not possible for European funds, because the best one can get is a yearly snapshot.
} 


\subsection{Summary and Conclusions}

This chapter investigates the performance of European equity funds using a survivorship bias controlled sample of 506 funds from the 5 most important mutual fund countries. In contrast to chapter 3, we here use several model specifications to examine fund performance. In line with chapter 4, we find the Carhart (1997) 4-factor asset-pricing model to be the most suitable model. This multi-factor model enables us to correct mutual fund performance by using factor-mimicking portfolios for size, book-to-market and stock price momentum.

Some interesting results follow from the 4-factor model. First of all it reveals a preference of European funds for small and high book-to-market stocks (value). Secondly, we show that small cap mutual funds as an investment style out-perform their benchmark, even after we control for common factors in stock returns. Finally 4 out of 5 countries deliver positive aggregate alphas, where only UK funds out-perform significantly. These observations appeared to be quite robust to the inclusion of a bond index, the weighting scheme of portfolios, time-variation in betas and the exclusion of the momentum factor.

The search for a "hot hands" effect provided only weak evidence of persistence in mutual fund performance, except for UK funds. Buying last year's top portfolio of UK mutual funds and selling last year's bottom portfolio of funds yields a return of $6.08 \%$ per year, which cannot be explained by common factors, stock price momentum or time-varying risks.

From US evidence, we know that most funds are able to follow the market before costs are deducted, with alphas insignificantly different from zero. We therefore examine European fund returns with costs added back. Now an interesting picture appears. French, Italian, Dutch and UK funds out-perform significantly, while German funds still underperform the market, though not significantly.

Finally, we investigate the influence of fund characteristics on risk-adjusted performance. We find expense ratio and age to be negatively related to risk adjusted performance, while fund assets are positively related.

Our results suggest that most European mutual funds, besides the obvious advantages of easy diversification and lower transaction costs, also deliver positive risk-adjusted performance to their investors. Contrary to most US evidence, the majority of European funds seems to be able to find and implement new information to offset their expenses, and therefore add value for the investor. A factor influencing this could be the smaller market importance of the European versus the US industry. While the US industry holds almost $30 \%$ of the domestic equity market, European funds are rather small players (up to $11 \%$ domestic market importance). If the mutual fund sector grows larger, relative to the market, it becomes more difficult to out-perform the market as a group. Because of their smaller market importance European mutual funds might be in a better position to follow or even beat the market. Especially European small cap funds seem to be able to profit from their market 
niche, as they significantly out-perform the market as a group. Along these lines it would be interesting to see what happens to European fund performance when the relative importance of this market grows in the future. 


\section{Chapter 6}

\section{Ethical Mutual Funds ${ }^{52}$}

\subsection{Introduction}

One of the astonishing new developments in the financial community is the rise of social and ethical investments during the last decade. ${ }^{53}$ While the origins of ethical investing date back many hundreds of years, the modern roots of social investing can be traced to the political climate of the 1960 's. ${ }^{54}$ Issues like the environment, civil rights and nuclear energy served to increase the social awareness of investors. Accordingly, mutual funds were set up which met the demand for incorporating ethical criteria in the investment process. This led to a dramatic increase in ethically managed mutual fund assets, an industry which now represents \$153 billion in the United States. If we would also include all US private and institutional ethically screened portfolios this number tops the \$2 trillion mark at the end of $20000^{55}$ At the moment almost $12 \%$ of money under professional management in the United States is part of a socially responsible portfolio.

Because of the sheer size and importance of this movement, both academics and practitioners have investigated the financial consequences of investing ethically, in other words: does it cost money to be ethical? The existing empirical evidence on US data suggests that ethical screening leads to similar or slightly less performance relative to comparable unrestricted portfolios. Among others, Diltz (1995), Guerard (1997) and Sauer (1997)

\footnotetext{
52 This chapter is based on R. Bauer, K. Koedijk and R. Otten, 'International Evidence on Ethical Fund Performance and Investment Style', LIFE Working Paper, 2002

${ }^{53}$ The term Ethical Investing will be used throughout this paper, instead of the US equivalent, Socially Responsible Investing (SRI).

${ }^{54}$ Ethical investing has ancient origins. In biblical times, Jews made laws with directives on how to invest according to ethical values. In the US, George Fox founded the Quakers in the $16^{\text {th }}$ century. This was a group of investors that applied social criteria to investing. based on their beliefs in human equality and non-violence. They were considered to be the first group of ethical investors.

${ }^{55}$ Figures by Social Invest Forum (2001 Trends Report)
} 
concluded that there were no statistically significant differences between the returns of ethically screened and unscreened universes.

Evidence on the performance of ethical mutual funds is mostly limited to the US and UK markets. Hamilton, Jo and Statman (1993) and Statman (2000) compared the returns of ethical and non-ethical US funds to each other, and to both the S\&P 500 and the Domini Social Index (DSI). Using Jensen's alpha it was concluded that no significant differences between risk-adjusted returns for ethical and non-ethical funds existed. Goldreyer and Diltz (1999) used an extended sample of ethical funds including equity, bond and balanced funds. Based on Jensen's alpha, Sharpe and Treynor ratios they found that social screening does not affect the investment performance of ethical mutual funds in any systematic way.

For the UK market four influential papers appeared during the last decade. The early studies compared ethical funds to market-wide indices like the FT all-share index. Using this methodology Luther, Matatko and Corner (1992) investigated the returns of 15 ethical unit trusts. Their results provided some weak evidence that ethical funds tend to out-perform general market indices. In addition a bias towards smaller companies for ethical funds was documented. Luther and Matatko (1994) confirmed this small cap bias and showed that comparing ethical funds to a small cap benchmark, improved their relative performance substantially. Subsequently Mallin, Saadouni and Briston (1995) attempted to solve this benchmark problem by using a matched pair analysis. Using a sample matched on the basis of fund size and formation date, they provide evidence of ethical mutual fund out-performance, based on Jensen's alpha. Finally Gregory, Matatko and Luther (1997) argued that matching based on fund size does not control for a small cap bias in the ethical portfolios. Based on a 2factor Jensen's alpha approach (including a small cap benchmark) they first confirm their prior observation of the small cap bias. Secondly, no significant difference between the financial performance of ethical and non-ethical unit trusts is found.

In addition to this small cap bias, a set of US papers appeared which attributed the recent out-performance of the DSI index, to sector and style biases. For instance Dibartolomeo (1996), Guerard (1997) and Kurtz (1997) report that the large-cap growth exposures of the DSI were driving ethical out-performance and not a so-called social factor.

The purpose this chapter is to review and to extend previous research on ethical mutual funds. More explicitly, we investigate the investment styles of ethical funds and adjust their performance for any style tilts. In order to do so we employ more elaborate multi-factor models that control for size, book to market, momentum and time-variation in betas. More specifically, we will build upon the work of Carhart (1997) and Ferson and Schadt (1996), which presents the current standard methodology on conventional mutual fund performance. As far as we know, no other studies on ethical mutual funds employ conditional multi-factor models to evaluate both performance and investment style.

Using an international sample of 103 US, UK and German ethical funds we address the central question whether ethical funds differ in terms of risk-adjusted return and 
investment style from conventional funds. Principal objective will be to investigate whether the return on ethical investments transcends market cycles and style preferences. ${ }^{56}$

The remainder of this chapter is organized as follows. Section 6.2 provides information on our data. Section 6.3 presents the empirical results. In section 6.4 we evaluate performance and investment style through time and finally we conclude in section 6.5.

\subsection{Data}

\subsubsection{General Market Overview}

Table 6.1 presents some figures on the size of the ethical mutual fund market in several selected countries. While the US market for ethical mutual funds rose from $\$ 12$ billion in 1995 to $\$ 153$ billion at the end of 2000 , the European market for ethical funds is still in an early stage of development. For instance in Belgium, France and Germany ethical funds do not even account for $1 \%$ of the total domestic market for mutual funds. Frontrunners in Europe are Sweden, The Netherlands and the United Kingdom. But even their relative importance is only half that of ethical funds in the US. Overall it can be said that the entire ethical mutual fund market still presents only a marginal part of the traditional market.

Table 6.1: Overview of Ethical Mutual Fund Market as of 30/12/2000

\begin{tabular}{|c|c|c|c|}
\hline Country & $\begin{array}{l}\text { \# of Ethical } \\
\text { Mutual funds }\end{array}$ & $\begin{array}{l}\text { Ethical assets } \\
\text { under } \\
\text { management in } \\
\text { million USD }\end{array}$ & $\begin{array}{c}\text { As a } \% \text { of total } \\
\text { mutual fund } \\
\text { assets }\end{array}$ \\
\hline Belgium ${ }^{\circ}$ & 26 & 602 & $0.80 \%$ \\
\hline France ${ }^{\circ}$ & 14 & 371 & $0.01 \%$ \\
\hline Germany & 22 & 1,317 & $0.04 \%$ \\
\hline Italy & 5 & 2,077 & $0.45 \%$ \\
\hline Sweden & 42 & 1,190 & $1.46 \%$ \\
\hline Switzerland ${ }^{*}$ & 22 & 1,011 & $1.12 \%$ \\
\hline The Netherlands & 11 & 1,309 & $1.20 \%$ \\
\hline United Kingdom & 55 & 6,390 & $1.35 \%$ \\
\hline United States & 230 & 153,000 & $2.26 \%$ \\
\hline \multicolumn{4}{|c|}{$\begin{array}{l}\text { Notes: This table presents the characteristics of the major European ethical mutual fund } \\
\text { markets and the United States. The first column presents the total number of ethical mutual } \\
\text { funds within a country. The second column provides the amount of total ethical mutual } \\
\text { fund assets under management (in USD). The last column presents the \% of the total } \\
\text { domestic fund market that is possessed by ethical funds. Sources: Avenzi, VBDO, EIRIS } \\
\text { Socialinvest, Arèse, IMUG Size at 31/12/99 }\end{array}$} \\
\hline
\end{tabular}

\footnotetext{
"S As we are not interested in individual ethical fund performance we will concentrate on the ethical market as a whole, by grouping funds into portfolios. Although we acknowledge that ethical funds employ a wide variety of ethical screens (for instance exclusion versus best-in-class) we think grouping funds enables us to address the question whether the ethical industry is efficient enough as a whole.
} 


\subsubsection{Ethical Mutual Funds}

To study the international performance and style of ethical mutual funds we construct a database containing the two most developed markets for ethical mutual funds, the United States and the United Kingdom. In addition we consider Germany, which is a relatively young but rapidly growing market. This allows us to consider the influence of experience and age on the relative performance of ethical versus conventional funds. We restrict our sample to pure domestic equity funds with at least 12 months of data, excluding balanced and guaranteed funds.

Using Morningstar (US), EIRIS (UK) and Ecoreporter (Germany) we constructed portfolios of mutual funds that invested their assets based on ethical screening. As a reference group we selected all other equity mutual funds in a certain country that did not explicitly claim to use ethical screening. Furthermore we divided funds into investment categories based on regional focus (domestic versus international), to enhance comparability. Return data was then collected from the CRSP Survivor-bias Free US Mutual Fund Database (United States) and Datastream (Germany and the United Kingdom). All returns are inclusive of any distributions, net of annual management fees and in local currency. This leads to a total sample of 103 ethical open-ended equity mutual funds and 4384 conventional funds with monthly logarithmic returns from January 1990 through March 2001.

As pointed out by Brown, Goetzmann, Ibbotson and Ross (1992), leaving out dead funds leads to an overestimation of average performance. Our US data was survivorship-bias free. To avoid a possible survivorship bias for Germany and the UK, we additionally add back funds that were closed at any point during the sample period. Through the national mutual fund publications (Unit Trust Yearbook and Hoppenstedt Fondsführer) we were able to identify dead German and UK funds. Return data for these funds was then collected from Datastream. Dead funds were included in the sample until they disappeared. After that the portfolios are re-weighted accordingly.

The percentage of disappearing funds throughout the sample period for Germany, the United Kingdom and the United States was $6 \%, 28 \%$ and $19 \%$ respectively. The influence of this becomes apparent if we compare the mean returns of all funds (dead + surviving) with the return on surviving funds only. Restricting our sample to surviving funds would lead us to overestimate average returns by $0.14 \%$ (Germany), $0.17 \%$ (United Kingdom) and $0.31 \%$ (United States) per year.

Table 6.2 describes the data we use in our subsequent analyses. Based on returns and Sharpe ratios it seems German and domestic US ethical funds under-perform both their conventional peers and the relevant indices. Only UK ethical funds appear to be able to match conventional funds when it comes to risk and return. If we look at some basic features of ethical mutual funds the smaller size and higher expense ratio becomes apparent. 
Table 6.2: Summary Statistics on Mutual Funds 1990:01 - 2001:03

\begin{tabular}{|c|c|c|c|c|c|c|}
\hline Country & Return & $\begin{array}{l}\text { Standard } \\
\text { deviation }\end{array}$ & $\begin{array}{r}\text { Sharpe } \\
\text { ratio }\end{array}$ & Size & $\begin{array}{r}\text { Expense } \\
\text { ratio }\end{array}$ & $\begin{array}{r}\text { \# of } \\
\text { Funds }\end{array}$ \\
\hline
\end{tabular}

\section{International}

Ethical

Conventional

4.77

14.13

$-0.06$

73

1.40

16

MSCI World

7.52

15.97

0.13

323

1.04

114

$\begin{array}{lll}11.97 & 19.06 & 0.33\end{array}$

\section{United Kingdom}

\section{Domestic}

Ethical

Conventional

9.81

13.11

0.16

48

1.24

20

9.58

13.64

0.14

176

1.19

300

FT-All

10.95

14.22

0.22

\section{International}

Ethical

8.92

15.16

0.08

89

1.49

12

Conventional

8.18

14.74

0.03

107

1.33

MSCI World

$8.52 \quad 15.99$

0.05

\section{United States}

\section{Domestic}

Ethical

Conventional

\subsection{9}

13.32

0.61

154

1.49

50

S\&P 500

15.38

13.89

0.75

\section{International}

Ethical

Conventional

11.95

13.91

0.57

140

1.71

5

\section{MSCI World}

11.88

13.59

0.58

385

1.62

1068

\section{Notes: Table 6.2}

\subsection{5}

12.51

0.83 regional objective. Ethical and conventional fund returns are calculated based on an equally weighted portfolio of all funds. The return data are annualized with reinvestment of all distributions, based on local currencies. All returns are net of expenses. Besides fund returns we also provide summary statistics on relevant market-wide benchmarks for each country and/or region. Average fund sizes are in million US dollars as of 31/12/2000. Costs are presented as a percentage of the assets invested. 


\subsubsection{Benchmarks}

In the basic 1-factor Jensen's alpha analysis we make use of well-known equity indices for each country. For all international funds we use the MSCI World index in local currency, while for domestic UK funds the FT-ALL share index, and for domestic US funds the S\&P 500 is employed. Besides these indices we also consider the explanatory power of several ethical indices that have been launched recently. These include the Domini Social index (DSI), the ethical balanced index by Ethical Investment Research Service (EIRIS) and the Dow Jones Sustainability indices (DJSGI). In constructing our version of the Carhart (1997) 4-factor model we consider all stocks in the Worldscope universe for each country/region. ${ }^{57}$ For the excess market return we take the return of all stocks in the Worldscope universe that are larger than \$25 million, minus the 1-month inter-bank rate. We then rank all stocks based on size and assign the bottom $20 \%$ of total market capitalization to the small portfolio. The remaining part goes into the large portfolio. SMB is the return difference between small and large. For the HML factor all stocks are ranked on their book-to-market ratio. In line with Fama and French (1992) we then assign the top 30\% of market capitalization to the high book-to-market portfolio and the bottom $30 \%$ to the low book-to-market portfolio. HML is obtained by subtracting the low from the high book-to-market return. The momentum factor portfolio is formed by ranking all stocks on their prior 12-month return. The return difference between the top $30 \%$ and bottom $30 \%$ by market capitalization then provides us with the momentum factor returns. ${ }^{58}$

\subsection{Empirical Results}

\subsubsection{CAPM Model}

The main model used in studies on ethical mutual fund performance is a CAPM based single index model. The intercept of such a model, $\alpha_{i}$, gives the Jensen alpha, which is usually interpreted as a measure of out- or under-performance relative to the used market proxy.

$$
R_{i t}-R_{f t}=\alpha_{i}+\beta_{i}\left(R_{m t}-R_{f t}\right)+\varepsilon_{i t}
$$

where $R_{i t}$ is the return on fund $i$ in month $t, R_{f}$ the return on a one month T-bill in month $t$, $R_{m t}$ the return on the local equity benchmark in month $t$ and $\varepsilon_{\mathrm{it}}$ an error term.

Table 6.3 presents the results of applying equation (6.1) on our database. Per country and within a country by region, we compute Jensen's alpha for both the portfolio of ethical funds

\footnotetext{
${ }^{37}$ Worldscope covers over $98 \%$ of total market capitalization per country. Which is much broader than the average $\mathrm{MSCl}$ index coverage $(70 \%)$.

${ }^{8}$ The construction of these factor portfolios was done using the on-line research tool by Style Research Ltd.
} 
and the portfolio of conventional funds. To enhance comparability we also add a portfolio which is constructed by subtracting conventional fund returns from ethical fund returns. This portfolio is then used to examine differences in risk and return between the two investment approaches.

From this table several conclusions can be drawn. First, it is clear that German and US ethical funds under-perform both the index and their conventional counterparts. Although only domestic US ethical funds exhibit significant (at 10\% level) under-performance, the differences in alpha estimates are larger than we would expect based on prior research. Second, German and UK ethical funds exhibit significantly less market risk, while for US funds no significant difference in market beta can be established. UK ethical funds finally seem to outpace conventional funds, but not significantly.

As ethical funds are constructed using several ethical, social and environmental screens, the common equity benchmarks used before might not be perfectly suitable to measure performance. To assess such possible bias we alternatively use several ethical indices to measure ethical fund performance. For all international funds we use the Dow Jones Sustainability Global Index (DJSI). Domestic UK funds are evaluated using the Ethical balanced index from EIRIS and domestic US funds are investigated by using both the Dow Jones Sustainability US Index and the Domini Social Index (DSI).

In table 6.4 we present the results of applying alternative ethical indices using a 1 factor model. For reasons of comparison we only investigate the 1994-2000 period, as the Dow Jones indices were launched in 1994. Accordingly, the results on the CAPM model with common indices are also based on the 1994-2000 period.

By using ethical indices three striking observations emerge. First, the ethical indices are less powerful in explaining fund performance compared to standard, non-ethical indices. In all but one case the $\mathrm{R}^{2}$ adj for the model with ethical indices is lower than the $\mathrm{R}^{2}{ }_{\text {adj }}$ of the standard CAPM model. Second, ethical funds are not able to out-perform their ethical index. Third, the conclusions based on the CAPM model with standard, non-ethical indices, seems to be quite robust to the use of ethical indices instead.

These results create an unexpected view on ethical mutual fund performance and investment behavior. It looks like standard non-ethical indices are more useful in explaining ethical fund returns than ethical indices. This raises the question whether ethical funds are really following distinct ethical investment styles. Or are ethical funds riding the wave of media attention for ethical investments, while in reality they are conventional funds in disguise. In the remainder of this chapter we will examine this concern in more detail, using more elaborate multi-factor models, which enable us to perform a style analysis. 
Table 6.3: Results CAPM model

\begin{tabular}{llll}
\hline Country/region & Alpha & Market & $\mathrm{R}^{2}{ }_{\text {adi }}$ \\
\hline Germany & & \\
\hline
\end{tabular}

\section{International}

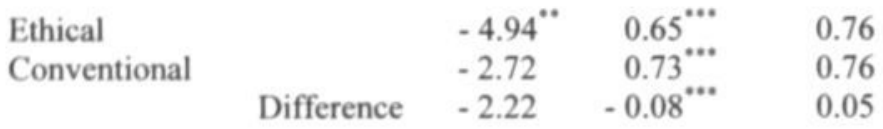

\section{United Kingdom}

\section{Domestic}

\begin{tabular}{|c|c|}
\hline Ethical & \\
\hline Conventional & \\
\hline
\end{tabular}

\section{International}

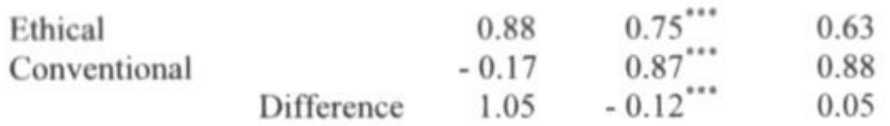

\section{United States}

\section{Domestic}

\begin{tabular}{|c|c|}
\hline Ethical & $0.89^{\cdots . . .}$ \\
\hline Conventional & $0.88^{* * *}$ \\
\hline & 0.01 \\
\hline
\end{tabular}

\section{International}

\begin{tabular}{|c|c|c|c|}
\hline Ethical & & -2.13 & $0.97^{\ldots . .}$ \\
\hline Conventional & & -1.92 & $0.94^{\cdots *}$ \\
\hline & Difference & -0.21 & 0.03 \\
\hline
\end{tabular}

Notes: The table reports the results of the estimation of equation (6.1) for the 1990:01 - 2001:03 period. Reported are the OLS estimates for each country and/or region, and within countries for both ethical and conventional funds. Difference is a portfolio which is constructed by subtracting conventional from ethical fund returns.

$$
R_{n}-R_{n}=\alpha_{i}+\beta_{i}\left(R_{m t}-R_{n}\right)+\varepsilon_{n}
$$

Where $R_{4}$ is the fund return, $R f_{4}$ the risk-free rate and $R m_{t}$ the return on the relevant benchmark of the individual countries. All returns are in local currencies and net of costs. All alphas are annualized.

-.. Significant at the $1 \%$ level

- Significant at the $5 \%$ level

- Significant at the $10 \%$ level 
Table 6.4: Alternative indices 1994-2000

\begin{tabular}{|c|c|c|c|c|c|c|c|c|c|c|c|c|}
\hline Country / region & $\begin{array}{c}\text { CAPM } \\
\text { alpha }\end{array}$ & Market & $\mathrm{R}^{2}$ adj & $\begin{array}{l}\text { DJSI } \\
\text { alpha }\end{array}$ & Market & $\mathrm{R}_{\text {adi }}^{2}$ & $\begin{array}{c}\text { EIRIS } \\
\text { alpha }\end{array}$ & Market & $\mathbf{R}_{\text {adi }}^{2}$ & $\begin{array}{l}\text { DSI } \\
\text { alpha }\end{array}$ & Market & $\mathbf{R}_{\text {adi }}^{2}$ \\
\hline \multicolumn{13}{|l|}{ Germany } \\
\hline $\begin{array}{l}\text { International } \\
\text { Ethical } \\
\text { Conventional } \\
\quad \text { Difference }\end{array}$ & $\begin{array}{l}-2.14 \\
-0.06 \\
-2.08\end{array}$ & $\begin{array}{r}0.69^{\cdots *} \\
0.80^{\cdots \cdots} \\
-0.11^{\cdots}\end{array}$ & $\begin{array}{l}0.80 \\
0.83 \\
0.10\end{array}$ & $\begin{array}{l}-3.20 \\
-1.95 \\
-1.25\end{array}$ & $\begin{aligned} & 0.69^{\cdots *} \\
& 0.85^{\cdots \cdots} \\
- & 0.16^{\cdots *}\end{aligned}$ & $\begin{array}{l}0.67 \\
0.78 \\
0.11\end{array}$ & & & & & & \\
\hline \multicolumn{13}{|l|}{ United Kingdom } \\
\hline $\begin{array}{l}\text { Domestic" } \\
\text { Ethical } \\
\text { Conventional } \\
\quad \text { Difference }\end{array}$ & $\begin{array}{r}-1.32 \\
-1.40 \\
0.08\end{array}$ & $\begin{array}{r}0.83^{\cdots \cdots} \\
0.92^{\cdots \cdots} \\
-0.09^{\cdots *}\end{array}$ & $\begin{array}{l}0.80 \\
0.90 \\
0.13\end{array}$ & & & & $\begin{array}{r}-1.12 \\
-1.44 \\
0.32\end{array}$ & $\begin{array}{r}0.82^{* \cdots} \\
0.89^{\cdots *} \\
-0.07^{\cdots *}\end{array}$ & $\begin{array}{l}0.80 \\
0.86 \\
0.06\end{array}$ & & & \\
\hline \begin{tabular}{l} 
International \\
Ethical \\
Conventional \\
\multicolumn{1}{c}{ Difference }
\end{tabular} & $\begin{array}{r}0.37 \\
-2.06 \\
2.43\end{array}$ & $\begin{array}{r}0.69^{\cdots *} \\
0.87^{\cdots *} \\
-0.18^{\cdots}\end{array}$ & $\begin{array}{l}0.55 \\
0.87 \\
0.12\end{array}$ & $\begin{array}{c}-1.91 \\
-5.04^{\circ *} \\
3.13\end{array}$ & $\begin{array}{c}0.62^{\cdots *} \\
0.80^{\cdots *} \\
-0.18^{* *}\end{array}$ & $\begin{array}{l}0.50 \\
0.84 \\
0.13\end{array}$ & & & & & & \\
\hline United States & & & & & & & & & & & & \\
\hline $\begin{array}{l}\text { Domestic } \\
\text { Ethical } \\
\text { Conventional } \\
\quad \text { Difference }\end{array}$ & $\begin{array}{l}-1.99 \\
-1.18 \\
-0.80\end{array}$ & $\begin{array}{l}0.90^{\cdots \cdots} \\
0.92^{\cdots *} \\
-0.02\end{array}$ & $\begin{array}{l}0.87 \\
0.78 \\
0.00\end{array}$ & $\begin{array}{r}-0.27 \\
0.69 \\
-0.96\end{array}$ & $\begin{array}{c}0.66^{\cdots} \\
0.67^{\cdots \cdots} \\
-0.01\end{array}$ & $\begin{array}{l}0.71 \\
0.62 \\
0.00\end{array}$ & & & & $\begin{array}{l}-1.83 \\
-0.87 \\
-0.96\end{array}$ & $\begin{array}{l}0.84^{\cdots \cdots} \\
0.84^{\cdots *} \\
0.00\end{array}$ & $\begin{array}{l}0.85 \\
0.74 \\
0.01\end{array}$ \\
\hline $\begin{array}{l}\text { International } \\
\text { Ethical } \\
\text { Conventional } \\
\quad \text { Difference }\end{array}$ & $\begin{array}{r}-1.93 \\
-2.86 \\
0.93 \\
\end{array}$ & $\begin{array}{l}0.95^{\cdots *} \\
0.93^{\cdots} \\
0.02\end{array}$ & $\begin{array}{l}0.75 \\
0.75 \\
0.00 \\
\end{array}$ & $\begin{array}{r}-3.12 \\
-3.92^{\circ} \\
0.80\end{array}$ & $\begin{array}{l}0.90^{\cdots *} \\
0.87^{\cdots *} \\
0.03\end{array}$ & $\begin{array}{l}0.83 \\
0.81 \\
0.01\end{array}$ & & & & & & \\
\hline $\begin{array}{l}\text { Notes: Table } 6.4 \text { repo } \\
\text { Indices (DJSI), the EIRI } \\
\text { the CAPM and alternati } \\
\text { 1991:01 - 1999:05 }\end{array}$ & $\begin{array}{l}\text { its the resu } \\
\mathrm{S} \text { balanced } \\
\text { e benchmar } \\
\text { Significant }\end{array}$ & $\begin{array}{l}\text { ts of using } \\
\text { thical index } \\
\text { ks results. } \\
\text { at the } 1 \% \text { lev }\end{array}$ & $\begin{array}{l}\text { altern: } \\
\text { and the } \\
\text { el " Sis }\end{array}$ & $\begin{array}{l}\text { tive indice: } \\
\text { DSI index. } \\
\text { nificant at t }\end{array}$ & $\begin{array}{l}\text { in estimatin } \\
\text { As the DJSI } \\
\text { he } 5 \% \text { level }\end{array}$ & $\begin{array}{l}8 \text { equati } \\
\text { vas laun } \\
\text { Signif }\end{array}$ & $\begin{array}{l}\text { on (6.1). } 7 \\
\text { ched in } 19 \\
\text { cant at the }\end{array}$ & $\begin{array}{l}\text { he indices } \\
94 \text { we only } \\
10 \% \text { level }\end{array}$ & $\begin{array}{l}\text { ed are } \\
\text { insider }\end{array}$ & $\begin{array}{l}\text { he Dow } \\
\text { he } 1994\end{array}$ & $\begin{array}{l}\text { Jones Sust } \\
2000 \text { perio }\end{array}$ & $\begin{array}{l}\text { inability } \\
\text { for both }\end{array}$ \\
\hline
\end{tabular}




\subsubsection{Multi-Factor Model}

The need for a multi-factor asset-pricing model stems from the recent literature on the crosssectional variation of stock returns (see, e.g. Fama \& French (1993, 1996) and Chan, Jegadeesh \& Lakonishok (1996)). The results of these studies lead us to question the adequacy of a single index model to explain mutual fund performance. Therefore the Fama \& French (1993) 3-factor model has been considered to give a better explanation of fund behavior. Besides a value-weighted market proxy, two additional risk factors are used, size and book-to-market. Although this model already improves average CAPM pricing errors, it is not able to explain the cross-sectional variation in momentum-sorted portfolio returns. Therefore Carhart (1997) extends the Fama-French model by adding a fourth factor that captures the Jegadeesh \& Titman (1993) momentum anomaly. The resulting model is consistent with a market equilibrium model with four risk factors, which can also be interpreted as a performance attribution model, where the coefficients and premia on the factor-mimicking portfolios indicate the proportion of mean return attributable to four elementary strategies.

Formally

$$
R_{i t}-R f_{t}=\alpha_{i}+\beta_{0 i}\left(R m_{t}-R f_{t}\right)+\beta_{1 i} S M B_{t}+\beta_{2 i} H M L_{t}+\beta_{3 i} M_{0 m}+\varepsilon_{i t}
$$

where

\begin{tabular}{|c|c|c|}
\hline \multirow[t]{2}{*}{$\mathrm{SMB}_{1}$} & $=$ & the difference in return between a small cap portfolio and a \\
\hline & & large cap portfolio at time $t$ \\
\hline \multirow[t]{3}{*}{$\mathrm{HML}_{1}$} & $=$ & the difference in return between a portfolio of high \\
\hline & & book-to-market stocks and one of low book-to-market \\
\hline & & stocks at time $\mathrm{t}$ \\
\hline \multirow[t]{2}{*}{ Mom $_{1}$} & $=$ & the difference in return between a portfolio of past 1 months \\
\hline & & winners and a portfolio of past 12 month losers at time $t$ \\
\hline
\end{tabular}

Table 6.5 summarizes the results of applying the multi-factor model. First, we notice a sharp increase in average $\mathrm{R}^{2}$ adj for the multi-factor model $(0.90)$, compared to the 1-factor CAPM model $(0.79)$. This indicates that the extended model is better able to explain mutual fund returns. Second, German and UK ethical funds exhibit significantly less market exposure compared to conventional funds, which corroborates our previous 1 -factor results. Third, German and UK ethical funds are heavily exposed to small caps while US funds on the other 
Table 6.5: 4-factor Carhart Model

\begin{tabular}{|c|c|c|c|c|c|c|}
\hline Country / region & $\begin{array}{c}\text { 4-factor } \\
\text { Alpha }\end{array}$ & Market & SMB & HML & Mom & $\mathbf{R}_{\text {adi }}^{2}$ \\
\hline \multicolumn{7}{|l|}{ Germany } \\
\hline \multicolumn{7}{|l|}{ International } \\
\hline $\begin{array}{l}\text { Ethical } \\
\text { Conventional } \\
\quad \text { Difference }\end{array}$ & $\begin{array}{l}-3.81^{*} \\
-2.26 \\
-1.55\end{array}$ & $\begin{array}{r}0.73 \cdots \\
0.82 \cdots \\
-0.09\end{array}$ & $\begin{array}{l}0.33^{*} \\
0.15^{\circ} \\
0.18^{\cdots}\end{array}$ & $\begin{array}{l}-0.03^{\circ} \\
-0.01 \\
-0.02\end{array}$ & $\begin{array}{r}0.05^{* *} \\
0.12^{* *} \\
-0.07^{* *}\end{array}$ & $\begin{array}{l}0.82 \\
0.83 \\
0.13\end{array}$ \\
\hline \multicolumn{7}{|l|}{ United Kingdom } \\
\hline \multicolumn{7}{|l|}{ Domestic } \\
\hline $\begin{array}{l}\text { Ethical } \\
\text { Conventional } \\
\quad \text { Difference }\end{array}$ & $\begin{array}{r}0.37 \\
-0.24 \\
0.61\end{array}$ & $\begin{array}{r}0.83 \cdots \\
0.92 \cdots \\
-0.09\end{array}$ & $\begin{array}{l}0.47 \cdots \\
0.32 \cdots \\
0.15 \cdots\end{array}$ & $\begin{array}{l}-0.05^{\cdots} \\
0.03^{\circ} \\
-0.07^{\cdots}\end{array}$ & $\begin{array}{l}0.04 . * \\
0.03 . \\
0.01\end{array}$ & $\begin{array}{l}0.93 \\
0.98 \\
0.37\end{array}$ \\
\hline \multicolumn{7}{|l|}{ International } \\
\hline $\begin{array}{l}\text { Ethical } \\
\text { Conventional } \\
\quad \text { Difference }\end{array}$ & $\begin{array}{l}2.26 \\
0.09 \\
2.17\end{array}$ & $\begin{array}{r}0.80^{\cdots} \cdots \\
0.90^{\cdots} \\
-0.10^{\cdots}\end{array}$ & $\begin{array}{l}0.71 \cdots \\
0.12 \cdots \\
0.59 \%\end{array}$ & 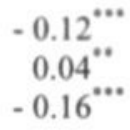 & $\begin{array}{l}0.13 \cdots \\
0.11 \cdots \\
0.02\end{array}$ & $\begin{array}{l}0.80 \\
0.92 \\
0.26\end{array}$ \\
\hline \multicolumn{7}{|l|}{ United States } \\
\hline \multicolumn{7}{|l|}{ Domestic } \\
\hline $\begin{array}{l}\text { Ethical } \\
\text { Conventional } \\
\quad \text { Difference }\end{array}$ & $\begin{array}{r}-0.46 \\
0.73 \\
-1.19\end{array}$ & $\begin{array}{l}0.91^{\cdots} \cdots \\
0.93^{\cdots} \\
-0.02\end{array}$ & $\begin{aligned} & 0.08 \cdots \\
& 0.18 \cdots \cdots \\
&-0.10 \cdots\end{aligned}$ & $\begin{array}{r}0.01 \\
0.03 \\
-0.02\end{array}$ & $\begin{array}{r}-0.01^{\circ} \\
0.03^{\circ} \\
-0.04^{\circ}\end{array}$ & $\begin{array}{l}0.96 \\
0.96 \\
0.19\end{array}$ \\
\hline \multicolumn{7}{|l|}{ International } \\
\hline $\begin{array}{l}\text { Ethical } \\
\text { Conventional } \\
\quad \text { Difference }\end{array}$ & $\begin{array}{l}-0.97 \\
-0.31 \\
-0.66\end{array}$ & $\begin{aligned} & 0.92 \cdots \\
& \cdots \\
- & 0.02\end{aligned}$ & $\begin{array}{r}-0.04 \\
0.20 \\
-0.24\end{array}$ & $\begin{array}{r}0.06 \\
0.08 . \\
-0.02\end{array}$ & $\begin{array}{l}0.20 \cdots \\
0.17 \% \\
0.03\end{array}$ & $\begin{array}{l}0.89 \\
0.94 \\
0.21\end{array}$ \\
\hline
\end{tabular}

Notes: The table reports the results of the estimation of equation (6.2) for the 1990:01 - 2001:03. Reported are the OLS estimates for each country and/or region, and within regions for both ethical and conventional funds. Difference is a portfolio which is constructed by subtracting conventional from ethical fund returns.

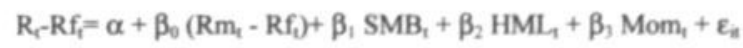

Where $R_{1}$ is the fund return, $\mathbf{R f}_{1}$ the risk-free rate, $\mathbf{R m}$ the return on the total Universe according to Worldscope, and SMB and HML the factor-mimicking portfolios for size and book-to-market. Mom is a factor-mimicking portfolio for the 12-month return momentum. All alphas in the table are annualized. Tstats are heteroskedasticity consistent.

-.. Significant at the $1 \%$ level

- Significant at the $5 \%$ level

Significant at the $10 \%$ level 
hand are relatively more invested in large caps. Fourth, all ethical funds are more growthoriented than value-oriented, if compared to conventional funds. This is in line with for instance Guerard (1997) who finds a growth bias in the DSI index. A reason for the high proportion of growth stocks may lie in the exclusion of traditional value sectors like chemical, energy and basic industries. As these represent a higher environmental risk, ethical portfolios are often under-weighted in them, which leads to a growth focus. Finally, after controlling for market risk, size, book-to-market and momentum the difference in return between ethical and conventional funds remains negative for Germany and the US, and positive for the UK. However, as none of the differences are significantly different from zero we cannot distinguish between the two.

\subsubsection{Conditional Multi-Factor Model}

It is well known that biases can arise if managers trade on publicly available information, in other words if dynamic strategies are employed. Average alphas calculated using a fixed beta estimate for the entire performance period are highly unreliable if expected returns and risks vary over time. Therefore Chen \& Knez (1996) and Ferson \& Schadt (1996) advocate conditional performance measurement. Based on our previous observations in chapter 4 and 5 we therefore test for the influence of introducing time-variation in betas on performance measurement.

Consider the following case were $\mathbf{Z}_{1-1}$ is a vector of lagged pre-determined instruments. Assuming that the beta for a fund varies over time, and that this variation can be captured by a linear relation to the conditional instruments, then $\beta_{i t}=\beta_{i 0}+\mathbf{B}_{i}^{\prime} \mathbf{Z}_{\uparrow-1}$, where $\mathbf{B}_{i}^{\prime}$ is a vector of response coefficients of the conditional beta with respect to the instruments in $\mathbf{Z}_{1-1}$. For a single index model the equation to be estimated then becomes

$$
R_{i t}-R f_{t}=\alpha_{i}+\beta_{i 0}\left(R m_{t}-R f_{t}\right)+B_{i}^{\prime} Z_{i-1}\left(R m_{t}-R f_{t}\right)+\varepsilon_{i t}
$$

Extending this model to a multi-factor version results in a conditional Carhart 4-factor model with time-varying betas. As instruments we use (1) the 1-month T-bill rate, (2) dividend yield on the market index, (3) the slope of the term structure and finally (4) the quality spread, by comparing the yield of government and corporate bonds. All instruments are lagged 1 month.

Table 6.6 presents the results of the conditional Carhart 4-factor model for the individual countries. While column 2 repeats the unconditional alphas from table 6.5 , the conditional alphas are in column 4 . In 8 out of 10 cases the hypothesis of constant betas can be rejected at the $5 \%$ level (see Wald test statistics in column 6 ), indicating strong time- 
Table 6.6: Unconditional versus Conditional performance evaluation

\begin{tabular}{|rrrrr}
\hline $\begin{array}{r}\text { Unconditional } \\
\text { 4f-alpha }\end{array}$ & $\mathbf{R}^{2}{ }_{\text {adj }}$ & $\begin{array}{r}\text { Conditional } \\
\text { 4f-alpha }\end{array}$ & $\mathbf{R}^{2}{ }_{\text {adj }}$ & $\begin{array}{c}\text { Wald } \\
\text { (p-value) }\end{array}$ \\
\hline Germany & & & & \\
\hline
\end{tabular}

\section{International}

\begin{tabular}{|llllll|} 
Ethical & $-3.81^{*}$ & 0.82 & $-3.45^{\circ}$ & 0.85 & 0.004 \\
Conventional & -2.26 & 0.83 & -1.06 & 0.87 & 0.000 \\
$\quad$ Difference & -1.55 & 0.13 & -2.39 & 0.20 & 0.003 \\
\hline United Kingdom & & & & & \\
\hline
\end{tabular}

\section{Domestic}

\begin{tabular}{lrrrrr} 
Ethical & 0.37 & 0.93 & 1.13 & 0.95 & 0.000 \\
Conventional & -0.24 & 0.98 & -0.36 & 0.98 & 0.050 \\
\multicolumn{1}{c}{ Difference } & 0.61 & 0.37 & $1.49^{\circ}$ & 0.51 & 0.000
\end{tabular}

\section{International}

$\begin{array}{lrrrrr}\text { Ethical } & 2.26 & 0.80 & 4.90^{* *} & 0.85 & 0.000 \\ \text { Conventional } & 0.09 & 0.92 & -1.01 & 0.92 & 0.120 \\ \quad \text { Difference } & 2.17 & 0.26 & 5.91 \cdots & 0.42 & 0.000\end{array}$

\section{United States}

Domestic

\begin{tabular}{lrrrrr} 
Ethical & -0.46 & 0.96 & -0.58 & 0.97 & 0.000 \\
Conventional & 0.73 & 0.96 & 0.99 & 0.98 & 0.000 \\
\multicolumn{1}{c}{ Difference } & -1.19 & 0.19 & $-1.57^{* *}$ & 0.45 & 0.000
\end{tabular}

International

\begin{tabular}{llllll} 
Ethical & -0.97 & 0.89 & -1.33 & 0.90 & 0.096 \\
Conventional & -0.31 & 0.94 & -0.54 & 0.94 & 0.004 \\
\multicolumn{1}{c}{ Difference } & -0.66 & 0.21 & -0.79 & 0.24 & 0.340 \\
\hline
\end{tabular}

Notes: This table presents the results from the unconditional (column 2 and 3 ) and conditional (column 4 and 5) performance model. The results from the unconditional model are imported from table 6.5 column 2 , the conditional model results stem from the multifactor version of equation (6.3). Here we allow the market, SMB, HML and PR6m betas to vary over time as a function of (1) the 1 month T-bill rate, (2) dividend yield (3) the slope of the term structure and (4) the quality spread. The last column of table 6.6 provides results for heteroskedasticity-consistent Wald tests to examine whether the conditioning information adds marginal explanatory power to the unconditional model. All alphas are annualized.

Significant at the $1 \%$ level

- Significant at the $5 \%$ level

- Significant at the $10 \%$ level 
variation in betas. The conditional alphas however strengthen our previous observations. German and US ethical funds under-perform, while UK ethical funds out-perform their conventional peers. Interestingly, US domestic ethical funds under-perform and UK ethical funds out-perform their conventional peers significantly using time-varying betas.

Finally, in figure 6.1 we present some dynamics of the relative style deviations of ethical funds versus conventional funds. As an example we consider UK domestic funds. The figure presents the differences in time-varying market beta, SMB, HML and Momentum between domestic UK Ethical and Conventional mutual funds. These results are obtained by evaluating the difference portfolio using the conditional multifactor version of equation (6.3).

This yields some interesting results concerning the consistency of ethical style deviations. First, ethical funds have lower betas throughout the 90 's. During the last 2 years however their beta rises dramatically and closely matches the conventional funds beta. Second, ethical funds are always relatively more invested in small caps, except for the beginning of the 90's and the last 2 years. Third, the growth bias in ethical portfolios is subject to quite some time-variation. Fourth, during our almost 12 year sample period ethical funds switched from contrarian to momentum strategies, relative to their conventional counterparts.

\subsection{Development of Relative Performance through Time}

The final issue we will touch upon in this study addresses the development of relative performance through time. In order to detect whether the rather young ethical investment sector is undergoing changes we divide our sample period into three non-overlapping subperiods. Table 6.7 reports the results for the 4 -factor model using 3 different sub-periods.

Examining the differences in alpha between ethical and conventional funds provides an interesting development. Where German and US funds under-perform their conventional peers significantly during the first 4 years of our sample period (1990-1993), this difference is gradually transformed into a slight out-performance during the most recent sub-period (19982001). It appears that US and German ethical funds went through a learning phase in which they first trailed conventional funds significantly while more recently they matched conventional fund performance. UK ethical fund performance clearly holds up with conventional funds throughout the almost 12 year period.

This intriguing development calls for further investigation. A possible source for the recent strong upsurge in relative ethical fund performance could be the launch of new funds, which could have learned from the "mistakes" from previous ones. For instance, Otten and Bams (2002) document a negative relationship between fund age and risk-adjusted performance for conventional European mutual funds. Evidence on the influence of age on ethical fund performance provides a different picture. According to Gregory, Matatko and 
Figure 6.1: Time-variation in differences between UK ethical and conventional fund exposures (domestic)
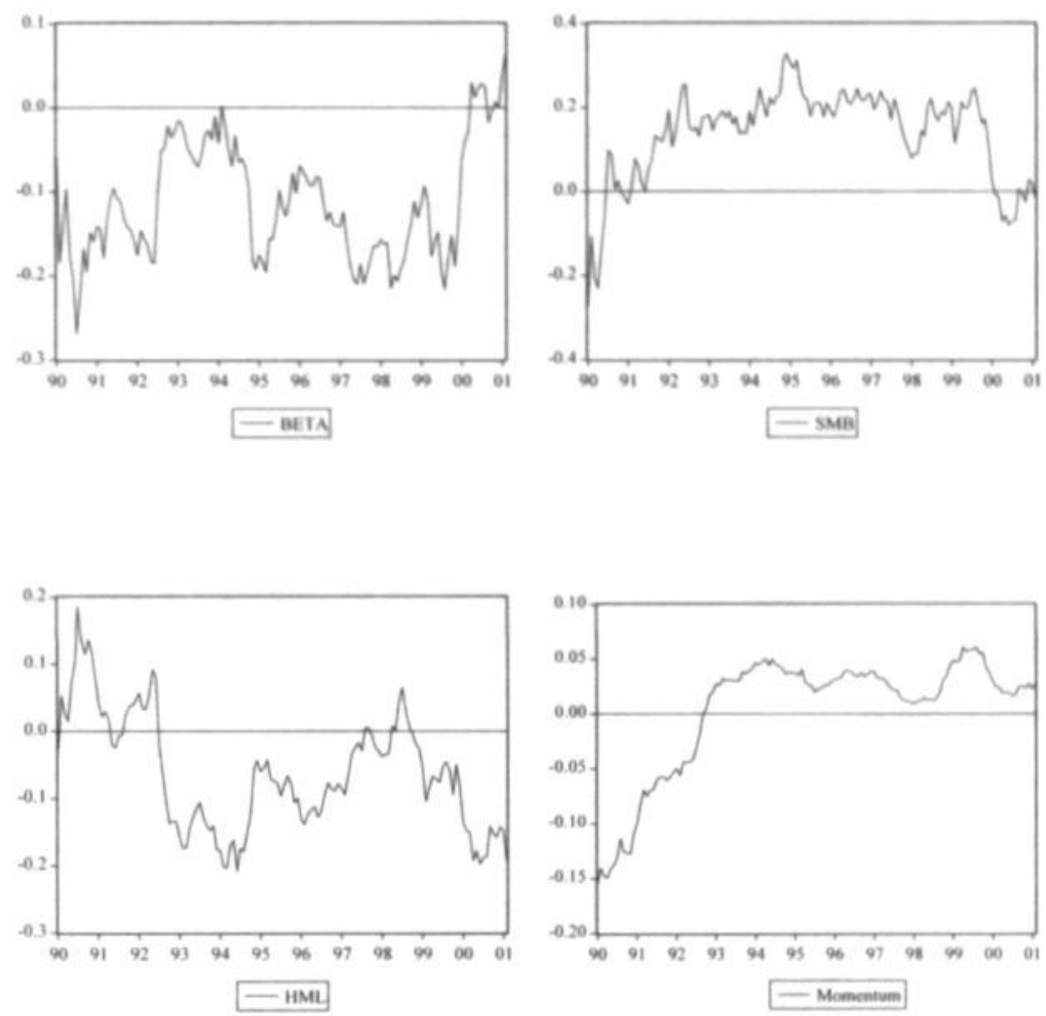

Notes: This figure presents the differences in time-varying market beta, SMB, HML and Momentum between domestic UK Ethical and Conventional mutual funds. These results are obtained by evaluating the difference portfolio using the conditional multifactor version of equation (6.3). In order to introduce time-variation we allow the market beta, SMB, HML and Momentum to vary over time as a function of (1) the 1 month T-bill rate, (2) dividend yield (3) the slope of the term structure and (4) the quality spread. Results are reported for the entire 1990:01-2001:03 period. 
Table 6.7: Difference between Ethical and Conventional funds for 3 Sub-periods

\begin{tabular}{lccc}
\hline Country / region & 4 factor alpha & 4 factor alpha & 4 factor alpha \\
$1990-1993$ & $1994-1997$ & $1998-2001$
\end{tabular}

Germany

$\begin{array}{llll}\text { International } & -2.56^{\circ} & -2.73^{\circ} & 1.12\end{array}$

\section{United Kingdom}

$\begin{array}{lrcr}\text { Domestic } & 0.65 & 1.33^{\circ} & 0.08 \\ \text { International } & -1.45 & 5.72^{* *} & 2.71\end{array}$

\section{United States}

\begin{tabular}{llll} 
Domestic & $-2.46^{\circ}$ & $-1.66^{\circ}$ & 1.63 \\
International & $-4.69^{\circ}$ & -0.53 & 1.18 \\
\hline
\end{tabular}

Notes: Table 6.7 presents the results of estimating equation (6.2) for 3 different subperiods. Reported are the differences between 4 factor alphas for ethical and conventional funds.

$R_{1}-R f_{1}=\alpha+\beta_{0}\left(R m_{1}-R f_{1}\right)+\beta_{1} S M B_{1}+\beta_{2} H L_{1}+\beta_{3} M_{10 m}+\varepsilon_{n}$

Where $R_{1}$ is the fund return, $R_{1}$ the risk-free rate, $R m$ the return on the total Universe according to Worldscope, and SMB and HML the factor-mimicking portfolios for size and book-to-market. Mom is a factor-mimicking portfolio for the 12-month return momentum. All alphas in the table are annualized. T-stats are heteroskedasticity consistent.

... Significant at the $1 \%$ level

Significant at the $5 \%$ level

Significant at the $10 \%$ level

Luther (1997) young funds perform worse. Their results however are somewhat sensitive to the definition of being a young fund.

In order to investigate the influence of new fund launches on the strong performance of ethical funds during 1998-2001, we construct two portfolios of funds based on age. The "Old" portfolio consists of funds that were launched before 1998, while the "Young" portfolio contains all funds that were launched in or after 1998, the start of our last subperiod.

Table 6.8 provides evidence to support the fact that ethical funds launched before 1998 (old) significantly out-performed funds that were set up after 1998 (young) in all 
countries and regions, except for the domestic UK funds. Especially the magnitude of this difference is striking as alphas are already corrected for investment style. Furthermore the new funds differ substantially from the older funds when it comes to market risk, size and book-to-market exposure. While the older funds have low market risk, the newer ones are significantly more exposed to the market index. In addition to that the small-cap growth bias for German and UK ethical funds is reduced significantly by the younger funds. These results indicate a switch in investment style by young ethical funds. Where the older funds had some distinctive loadings on certain investment styles, the younger funds are more closely following the general market, and more importantly, following their conventional counterparts.

The latter point is supported by table 6.9, which presents the difference in performance and investment style between old ethical funds versus conventional funds and young ethical funds versus conventional funds. While the older ethical funds clearly deviated from conventional funds with respect to market risk, small cap exposure and value/growth, the younger funds follow less pronounced styles. Especially their market beta is much closer to the conventional fund beta, which indicates a stricter following of general market movements. This is supported by the lower $\mathrm{R}^{2}$ adj of the difference between young ethical funds and conventional funds. Finally the differences in alpha appear to support the fact that the older funds finally have caught up with conventional funds, while funds that were launched recently still trailed their conventional peers. This could point towards a learning effect that ethical funds have to go through before their financial return is comparable to conventional mutual funds. ${ }^{59}$

\footnotetext{
${ }^{50}$ An alternative explanation for the under-performance of young ethical funds could be the recent bear market, starting at the end of 1999. As our multi-factor model however controls for market risk and style deviations this cannot fully explain the under-performance. Possibly the setting up of a new fund leads to high costs, which hurts investment performance.
} 
Table 6.8: Old versus Young Ethical Funds, 1998:01 - 2001:03

\begin{tabular}{|c|c|c|c|c|c|c|}
\hline Country / region & $\begin{array}{c}\text { 4-factor } \\
\text { Alpha }\end{array}$ & Market & SMB & HML & Mom & $\mathbf{R}_{\text {adj }}^{2}$ \\
\hline \multicolumn{7}{|l|}{ Germany } \\
\hline \multicolumn{7}{|l|}{ International } \\
\hline Old & 4.06 & $0.72^{\cdots *}$ & $0.44^{* * *}$ & $-0.18^{* *}$ & -0.07 & 0.78 \\
\hline Young & -1.30 & $0.90^{* \cdots}$ & 0.09 & -0.00 & 0.01 & 0.80 \\
\hline Difference & $5.36^{\circ "}$ & $-0.18^{\cdots *}$ & $0.35^{* *}$ & $-0.18^{* *}$ & -0.08 & 0.27 \\
\hline \multicolumn{7}{|l|}{ United Kingdom } \\
\hline \multicolumn{7}{|l|}{ Domestic } \\
\hline Old & 0.33 & $0.83^{\cdots *}$ & $0.42^{* *}$ & $-0.08^{* *}$ & $0.05^{\circ}$ & 0.94 \\
\hline Young & 0.16 & $0.93^{\cdots}$ & $0.27^{* . .}$ & $0.03^{\circ}$ & $0.03^{\circ}$ & 0.97 \\
\hline Difference & 0.17 & $-0.10^{\cdots *}$ & $0.15^{\cdots *}$ & $-0.11^{* *}$ & 0.02 & 0.51 \\
\hline \multicolumn{7}{|l|}{ International } \\
\hline Old & $9.57^{\circ}$ & $0.65^{* *}$ & $0.78^{* *}$ & $-0.42^{* * *}$ & -0.01 & 0.77 \\
\hline Young & -2.83 & $0.82^{\cdots . .}$ & $0.46^{\cdots . .}$ & $-0.15^{\circ}$ & 0.01 & 0.84 \\
\hline Difference & $12.59^{\circ}$ & $-0.17^{\circ 0}$ & 0.32 & $-0.27^{\circ}$ & -0.02 & 0.40 \\
\hline \multicolumn{7}{|l|}{ United States } \\
\hline \multicolumn{7}{|l|}{ Domestic } \\
\hline Old & 1.26 & $0.97 \cdots$ & $0.05^{\cdots *}$ & $-0.13^{\circ}$ & -0.01 & 0.98 \\
\hline Young & -3.54 & $1.09 \%$ & 0.28 & $-0.12^{* *}$ & -0.01 & 0.90 \\
\hline Difference & $4.80^{\circ}$ & $-0.12^{*}$ & $-0.23^{\cdots}$ & 0.01 & 0.00 & 0.47 \\
\hline \multicolumn{7}{|l|}{ International } \\
\hline Old & 4.18 & $0.92 \cdots$ & -0.02 & 0.05 & $0.32^{* * *}$ & 0.91 \\
\hline Young & -0.97. & $0.96 .$. & -0.03 & $0.18^{* *}$ & 0.14. & 0.88 \\
\hline Difference & $5.15^{* *}$ & $-0.04^{* *}$ & -0.01 & $-0.13^{* *}$ & $0.18^{* *}$ & 0.70 \\
\hline
\end{tabular}

Notes: Table 6.8 presents the results of estimating equation (6.2) for 2 sub-groups of ethical funds. All funds launched before 1998 go into the "Old" portfolio, while funds launched after 1998 are in the "Young" portfolio. Reported are the OLS estimates for each country and/or region, and within regions for both old and young ethical funds. Difference is a portfolio which is constructed by subtracting young from old fund returns.

$$
R_{1}-R f_{1}=\alpha+\beta_{0}\left(R m_{4}-R f_{3}\right)+\beta_{1} S M B_{1}+\beta_{2} H M L_{1}+\beta_{3} M o m_{4}+\varepsilon_{\mathrm{in}}
$$

Where $R_{1}$ is the fund return, $R f_{1}$ the risk-free rate, $R m$ the return on the total Universe according to Worldscope, and SMB and HML the factor-mimicking portfolios for size and book-to-market. Mom is a factor-mimicking portfolio for the 12-month return momentum. All alphas in the table are annualized. Tstats are heteroskedasticity consistent.

... Significant at the $1 \%$ level

. Significant at the $5 \%$ level

- Significant at the $10 \%$ level 
Table 6.9: Differences between ethical and conventional funds by age, 1998:01 - 2001:03

\begin{tabular}{|c|c|c|c|c|c|c|}
\hline Country / region & $\begin{array}{l}\text { 4-factor } \\
\text { Alpha }\end{array}$ & Market & SMB & HML & Mom & $\mathbf{R}_{\text {adi }}^{2}$ \\
\hline \multicolumn{7}{|l|}{ Germany } \\
\hline \multicolumn{7}{|l|}{ International } \\
\hline $\begin{array}{l}\text { Difference Old } \\
\text { Difference Young }\end{array}$ & $\begin{array}{r}3.26 \\
-2.09\end{array}$ & $\begin{array}{c}-0.17^{* *} \\
0.00\end{array}$ & $\begin{aligned} & 0.32^{* * *} \\
- & 0.01\end{aligned}$ & $\begin{array}{r}-0.02 \\
0.15\end{array}$ & $\begin{array}{l}-0.10^{\circ} \\
-0.02\end{array}$ & $\begin{array}{l}0.28 \\
0.24\end{array}$ \\
\hline \multicolumn{7}{|l|}{ United Kingdom } \\
\hline \multicolumn{7}{|l|}{ Domestic } \\
\hline $\begin{array}{l}\text { Difference Old } \\
\text { Difference Young }\end{array}$ & $\begin{array}{l}0.26 \\
0.16\end{array}$ & $\begin{array}{l}-0.09^{* *} \\
-0.05\end{array}$ & $\begin{array}{l}0.15^{* * *} \\
0.04\end{array}$ & $\begin{array}{l}-0.11^{*} \\
-0.13^{* .}\end{array}$ & $\begin{array}{l}0.01 \\
0.03\end{array}$ & $\begin{array}{l}0.51 \\
0.25\end{array}$ \\
\hline \multicolumn{7}{|l|}{ International } \\
\hline $\begin{array}{l}\text { Difference Old } \\
\text { Difference Young }\end{array}$ & $\begin{array}{l}10.39^{\circ} \\
-2.76\end{array}$ & $\begin{array}{l}-0.22^{\circ *} \\
-0.14^{\circ}\end{array}$ & $\begin{array}{l}0.68^{* \cdots} \\
0.40^{\cdots *}\end{array}$ & $\begin{array}{l}-0.45^{* *} \\
-0.17^{* *}\end{array}$ & $\begin{array}{l}-0.06 \\
-0.02\end{array}$ & $\begin{array}{l}0.61 \\
0.30\end{array}$ \\
\hline \multicolumn{7}{|l|}{ United States } \\
\hline \multicolumn{7}{|l|}{ Domestic } \\
\hline $\begin{array}{l}\text { Difference Old } \\
\text { Difference Young }\end{array}$ & $\begin{array}{r}0.63 \\
-4.16\end{array}$ & $\begin{array}{c}-0.07^{* .} \\
0.05\end{array}$ & $\begin{array}{c}-0.13^{\circ . *} \\
0.10^{\circ}\end{array}$ & $\begin{array}{l}-0.03 \\
-0.04\end{array}$ & $\begin{array}{l}-0.05^{\circ} \\
-0.04\end{array}$ & $\begin{array}{l}0.72 \\
0.13\end{array}$ \\
\hline International & & & & & & \\
\hline $\begin{array}{l}\text { Difference Old } \\
\text { Difference Young }\end{array}$ & $\begin{array}{r}3.75^{\circ} \\
-1.41 \\
\end{array}$ & $\begin{array}{l}0.00 \\
0.05\end{array}$ & $\begin{array}{l}-0.20^{* *} \\
-0.21^{* *}\end{array}$ & $\begin{array}{r}-0.11^{\circ} \\
0.02\end{array}$ & $\begin{array}{r}0.08^{\circ} \\
-0.10^{\circ} \\
\end{array}$ & $\begin{array}{l}0.51 \\
0.35\end{array}$ \\
\hline
\end{tabular}

Notes: Table 6.9 presents the results of estimating equation (6.2) for 2 sub-groups of ethical funds. All funds launched before 1998 go into the "Old" portfolio, while funds launched after 1998 are in the "Young" portfolio. Reported are the OLS estimates for the difference between old ethical funds and conventional funds (difference old) and the difference between young ethical fund and conventional funds (difference young).

$$
R_{1}-R_{i}=\alpha+\beta_{0}\left(R m_{1}-R f_{1}\right)+\beta_{1} S M B_{1}+\beta_{2} H L_{1}+\beta_{3} M o m_{1}+\varepsilon_{m}
$$

Where $R_{t}$ is the fund return, $\mathbf{R f}_{4}$ the risk-free rate, $\mathbf{R m}$ the return on the total Universe according to Worldscope, and SMB and HML the factor-mimicking portfolios for size and book-to-market. Mom is a factor-mimicking portfolio for the 12 -month return momentum. All alphas in the table are annualized. T. stats are heteroskedasticity consistent.

... Significant at the $1 \%$ level

- Significant at the $5 \%$ level

- Significant at the $10 \%$ level 


\subsection{Conclusion}

Although ethical mutual fund assets witnessed an unprecedented growth in assets during the last decade, the industry still only presents a small part of the total mutual fund market. A crucial factor that determines the incorporation of ethical mutual funds into the mainstream investment area is their financial performance. Using an international database of 103 ethical mutual funds we therefore analyze ethical fund performance and investment style.

While most of the previous work on ethical mutual fund performance is conducted using market wide indices, we explore the added value of more elaborate multi-factor models. This not only improves performance measurement but also enables us to investigate ethical mutual fund investment styles in more detail.

After employing a CAPM 1-factor model, using both standard an ethical indices, we consider a Carhart (1997) 4-factor asset-pricing model that controls for size, book-to-market and stock price momentum. From this four interesting results emerge. First, German and US ethical funds under-perform both their relevant indices and conventional peers, while UK ethical funds show a slight out-performance. None of these differences however are statistically significant after we control for common factors like size, book-to-market and momentum. Second, ethical indices perform worse than standard indices in explaining ethical fund performance. Third, ethical funds exhibit distinct investment styles if compared to conventional funds. For instance, German and UK ethical funds exhibit significantly less market exposure compared to conventional funds and are heavily exposed to small caps. US funds on the other hand are relatively more invested in large caps. In addition, all ethical funds are more growth-oriented than value-oriented, if compared to conventional funds. Fourth, allowing for time-variation in betas partly corroborates our previous results on performance. German and US ethical funds under-perform, while UK ethical funds outperform their conventional peers. Interestingly, US domestic ethical funds under-perform and UK ethical funds out-perform their conventional peers significantly using time-varying betas.

Subsequently we investigate the relative returns of ethical versus conventional funds through time, using 3 sub-periods. This provides support for the idea that German and US ethical funds went through a so-called learning phase. After significant under-performance in the beginning of the 1990's, they match conventional fund performance during the 1998-2001 period. In addition we find a strong age effect if funds are divided based on launch date. Funds that were set up before 1998 significantly out-performed funds that were launched after 1998. These younger funds also changed their investment style. While the older ethical funds clearly deviated from conventional funds with respect to market risk, small cap exposure and value/growth, the younger funds follow much less pronounced investment styles. Finally the differences in alpha appear to support the fact that the older funds finally have caught up with 
conventional funds, while funds that were launched recently still trail their conventional peers.

In conclusion, we document corroborative evidence for the result that ethical funds do not under-perform relative to conventional funds. Even after controlling for investment style we find no significant differences in risk-adjusted returns between ethical and conventional funds. However we differentiate previous results by documenting a learning effect. After a period of strong under-performance, older ethical funds finally are catching up, while younger funds continue to under-perform both the index and conventional peers. 



\section{Chapter 7}

\section{Return-Based Style Analysis ${ }^{60}$}

\subsection{Introduction}

The previous chapters mainly dealt with the performance of mutual funds, using asset-pricing models. For instance, chapter 5 describes European mutual fund performance and chapter 6 the performance of ethical mutual funds. In this chapter we take a slightly different approach. Using a UK database we perform a style analysis to examine whether mutual funds stick to their stated investment style, using an attribution analysis. Style analysis of mutual funds is an important tool that seeks to help investors to understand a mutual fund's investment policy and objective. No direct information is available on the actual portfolio composition of a mutual fund. Although reading the fund's prospectus seems an obvious starting point, recent research by DiBartolomeo and Witkowski (1997), Brown and Goetzmann (1997) and Kim, Shukla and Tomas (1999) presents evidence of serious misclassifications if self-reported investment objectives are compared to actual styles. This calls for better techniques to measure and analyze mutual fund portfolio composition and behavior.

A popular approach that is used for detecting mutual fund styles is return-based style analysis. Typically, the fund return is compared with the return on a number of selected passive style indices. The indices represent distinct investment styles within particular asset classes (e.g. value, growth, and small caps). Using regression analysis a mixture of indices is determined that has moved most with the fund. Style analysis thus is the construction of a portfolio of indices that best mimics the historical performance of a mutual fund. The style of the fund is represented by the loadings (regression coefficients) on the indices.

\footnotetext{
${ }^{\text {w0 }}$ This chapter is based on R. Otten and D. Bams, 'Statistical Tests for Return-Based Style Analysis', LIFE Working Paper, 2001
} 
Sharpe $(1988,1992)$ has proposed an econometric technique to conduct return-based style analysis. This technique involves a constrained regression that uses several asset classes to replicate the historical return pattern of a portfolio. The constraints are imposed to enhance an intuitive interpretation of the coefficients. First, to interpret the coefficients as weights within a portfolio the factor loadings are required to add up to one. Second, coefficients should be positive to reflect the short-selling constraint most fund managers are subject to. A non-linear regression analysis is proposed to arrive at point estimates for the portfolio weights. The ultimate idea is to check whether the estimated portfolio weights correspond with the targeted investment style of the mutual fund.

The point estimates for the portfolio weights only provide a limited picture of the information that is available in the historic fund returns. In addition to the point estimates, the asymptotic distribution function of the parameter estimates is helpful in determining the accurateness of the estimates. However, the constraints on the parameters make it less straightforward to arrive at the asymptotic distribution of the parameter estimates. Lobosco and DiBartolomeo (1997) propose approximate confidence intervals for the coefficients. When point estimates are not close to zero or one, this information is accurate in determining the preciseness of the style weights. These confidence intervals still provide limited information as they do not allow for tests on multiple coefficients. ${ }^{61}$ In this chapter we propose an exact approach to arrive at the asymptotic distribution of the parameter estimates. We employ the Kuhn-Tucker optimization algorithm to deal with the inequality constraints. In case of Sharpe's style analysis model the optimal parameter estimates for the model with constraints can be expressed in terms of the optimal parameter estimates for the model without the constraints. We then employ the bootstrapping algorithm to arrive at the asymptotic distribution of the parameters. In fact we are considering the impact of parameter uncertainty on style analysis. The effect of parameter uncertainty has also been incorporated in other academic studies. See for example Anderson, Hansen and Sargent (2000), Barberis (2000) and Maenhout (2000).

The purpose of this chapter is to show that the asymptotic distribution of the portfolio weights leads to relevant additional information beyond the information contained in the point estimates only. This information is useful for three reasons: (1) to assess the preciseness of estimated style coefficients, (2) to test whether coefficients are significantly different from zero and (3) to determine whether style coefficients are significantly different from each other. This extra information has important practical implications for the fund misclassification phenomenon. Incorporating the asymptotic distribution of style weights makes it easier to track down misclassified funds and subsequently analyze their behavior. To

\footnotetext{
${ }^{61}$ In case of non-binding restrictions at least also the covariance terms of parameter estimates are required. In general however the asymptotic distribution should be used, since the assumption of a asymptotic normal distribution does not apply anymore when constraints become binding.
} 
illustrate these three main improvements, and to exemplify the application with respect to the fund misclassification phenomenon, we consider a sample of UK equity mutual funds.

The remainder of the chapter is organized as follows. In section 7.2 some general remarks are made concerning return-based style analysis. In section 7.3 the econometric technique to arrive at the asymptotic distribution is derived. In section 7.4 we describe the data that will be used in the empirical application. Section 7.5 contains empirical results for our approach, while in section 7.6 we address the robustness of these results. Finally section 7.7 concludes the chapter.

\subsection{Stylized Facts of Sharpe's Model for Return-Based Style Analysis}

The theory of return-based style analysis asserts that a manager's investment style, both past and present, can be determined by comparing the manager's returns to the returns of a number of selected passive indices. Because of the minimal data requirements (only returns) and low level of sophistication needed, return-based style analysis has gained widespread attention among plan sponsors, investment consultants and private investors. Sharpe proposes the following econometric model:

$$
R_{t}=\alpha+\sum_{k=1}^{N} \beta_{k} I_{k}+u_{i} \quad t=1, \ldots, T
$$

where $R_{t}$ denotes the mutual fund return at time t, $N$ is the number of asset class factors, $\beta_{k}$ is a factor loading that expresses the sensitivity of the fund return to the factor-mimicking portfolio return of index $\mathrm{k}, I_{\mathrm{k} t}$ denotes the return of index $\mathrm{k}$ at time $\mathrm{t}$ and $u_{i}$ reflects idiosyncratic noise. The factor loadings are restricted to add-up to one, in order to give them the interpretation of portfolio weights:

$$
\sum_{i=1}^{N} \beta_{i}=1
$$

Finally, to meet the short-selling constraint that fund managers are mostly subject to, the following inequality constraints are imposed on the factor loadings:

$$
\beta_{k} \geq 0 \quad k=1, \ldots, N
$$


Equation (7.2) makes that we can interpret the factor loadings as portfolio weights. In this context $\sum_{k=1}^{N} \beta_{k} I_{k}$ has the interpretation of the return on a passive portfolio with the same style as the fund. In the next section we provide detailed information on the estimation algorithm for the factor loadings. Given parameter estimates for the factor loadings, the model in equation (7.1) subject to the constraints in (7.2) and (7.3) may have two applications: asset allocation and performance benchmarking.

Since the factor loadings have the interpretation of portfolio weights, return-based style analysis is a tool to determine the asset allocation of the particular mutual fund. Besides examining the prospectus, talking to a fund's management and investment consultants, returnbased style analysis helps the investor to determine a fund's investment style.

If we interpret the estimated style weights as exposures to passive indices, return based style analysis is also applicable as a performance measurement tool. The return obtained by a fund in each month can be compared with the return on a mix of asset classes with the same estimated style. In equation (7.1) the systematic difference between the fund return and the estimated style index is represented by the intercept, $\alpha$. Because the input for return-based style analysis are indices which are; (1) a viable alternative (2) not easily beaten (3) identifiable and (4) easily replicated, the major criteria for measuring performance are met.

A crucial ingredient that may heavily influence the outcome of return-based style analysis is the choice of the appropriate benchmarks. While Sharpe (1992) uses a detailed 12asset class factor model, simpler models often yield more sensible results, like for instance in Lobosco and DiBartolomeo (1997). A few prerequisites should be met before any reliable results are to be obtained. First, the benchmarks should be mutually exclusive. Secondly, they should not be linear combinations of other indices. For instance, a mid-cap index is probably replicated by a weighted combination of a large cap index and a small cap index, and should therefore not be included. A way to control for this possible problem is to look at cross correlations and standard deviations. If correlations between specific benchmarks are too high, we could consider dropping some of them to diminish multicollinearity problems. The resulting model should be able to span the whole portfolio asset mix.

\subsection{Econometric Method}

One shortcoming in Sharpe's style analysis is the fact that it only focuses on point estimates for the factor loadings, ignoring the information that is available in the asymptotic distribution of the parameter estimates. A practical reason for not reporting the asymptotic distribution may be that this is not a straightforward task. The restrictions in (7.2) and (7.3) complicate the calculation of this distribution. The standard OLS estimator does not suffice anymore, because this usually does not lead to parameter estimates that meet the restrictions. Yet, the 
asymptotic distribution may play an important role in testing significance of factor loadings (Is there statistical indication that the fund invests in a particular type of securities?). Another relevant test is to check whether a fund is more invested in one type of style than in another one, also requiring the asymptotic distribution.

In this section we describe the Kuhn-Tucker algorithm for Sharpe's style analysis model. For similar derivations and applications of statistical inference in constrained linear models see Gouriéroux, Holly and Monfort (1982), Gouriéroux and Monfort (1995) and Kodde and Palm (1986).

Sharpe's model as described in equation $(7.1)-(7.3)$ is compactly rewritten in matrix algebra terms as follows:

$$
\begin{aligned}
& Y=X \beta+u \\
& j^{\prime} \beta=1 \\
& \beta_{k} \geq 0 \quad k=2, \ldots, N+1
\end{aligned}
$$

where $\mathrm{Y}$ is a $(T \times 1)$ vector of fund returns, $\mathrm{X}$ denotes a $T \times(N+1)$ matrix where the elements in the first column are all one, and the other columns consist of $\mathrm{N}$ style index returns, $\mathrm{u}$ is a $T \times 1$ vector with error terms. The $(N+1) \times 1$ vector $\beta$ has as first element the intercept $\alpha$ and the other elements are the style index sensitivities denoted by $\beta_{k}(k=1, \ldots, N)$. In Sharpe's model the factor loadings add-up to one and all the factor loadings are non-negative. Note that $j$ is a $(N+1) \times 1$ vector where the first element is zero and the other elements are equal to one.

We are interested in the parameter estimates together with the associated asymptotic distribution for the vector $\beta$. Because of the inequality constraints we employ the estimation algorithm introduced by Kuhn-Tucker. In the appendix we show that in the case of a linear regression model this Kuhn-Tucker estimator, denoted as $b_{K T}$, can be written in terms of a socalled Lagrange estimator, $b_{L}$. A Lagrange estimator finds optimal parameter estimates subject to equality constraints. Next, the Lagrange estimator can be expressed in terms of the ordinary least squares (OLS) unconstrained estimator, $b_{t}$.

The principle behind the Kuhn-Tucker algorithm lies in the treatment of the inequality constraints on the factor sensitivities. When a particular constraint is non-binding then its estimator for the associated factor loading is equal to the OLS estimator. When the particular constraint is binding then its estimator is equal to the Lagrange estimator. Beforehand it is not known which constraints will be binding and which will be non-binding. Therefore we consider the estimators for all possible combinations of binding and non-binding restrictions. 
The combination that leads to the lowest residual sum of squares and that meets all constraints then leads to the optimal parameter estimate for $\beta$. In appendix 7A we show that the KuhnTucker solution is expressed in terms of the unconstrained least squares estimator as follows:

$$
b_{K T}=\min _{S \in \Omega}\left\{\left(Y-X b_{s}\right)\left(Y-X b_{s}\right) \mid f^{\prime} b_{s}=1 ; S b_{s}=0\right\}
$$

where

$$
\begin{aligned}
& b_{S}=\left[I_{N+1}-V S^{\prime}\left(S V S^{\prime}\right)^{-1} S\right] P+\left[I_{N+1^{-}} V S^{\prime}\left(S V S^{\prime}\right)^{-1} S\right]\left[l_{N+1}-P\right]_{b_{U}} \\
& P=\left(X^{\prime} X\right)^{-1} j\left[j^{\prime}\left(X^{\prime} X\right)^{-1} j\right]^{-1} \\
& V=\left(I_{N+1}-P j^{\prime}\right)\left(X^{\prime} X\right)^{-1}
\end{aligned}
$$

and $I_{N+1}$ is the $(N+1) \times(N+1)$ identity matrix. Let $\mathrm{S}$ be the matrix that represents the binding inequality constraints, i.e. the associated equality constraint reads

$$
S \beta=0
$$

For example, the following $2 \times(N+1)$ matrix represents the sub-problem where the second and the third parameter are binding:

$$
S=\left(\begin{array}{llllll}
0 & 1 & 0 & 0 & \cdots & 0 \\
0 & 0 & 1 & 0 & \cdots & 0
\end{array}\right)
$$

The set of all possible matrices $\mathrm{S}$ representing combinations of binding and non-binding constraints is given by $\Omega$. The expressions above show that the Kuhn-Tucker solution is identical to the Lagrange estimator $\left(b_{s}\right)$ for one of the possible sub-problems $(S \in \Omega)$, i.e. combination of binding and non-binding constraints. In equation (7.8) we show that this estimator is related to the unconstrained estimator and to some deterministic matrices. The unconstrained least squares estimator reads

$$
b_{U}=\left(X^{\prime} X\right)^{-1} X^{\prime} Y
$$

and the associated variance covariance matrix is given by 


$$
\hat{V}\left(b_{s}\right)=\hat{\sigma}^{2}\left(X^{\prime} X\right)^{-1}
$$

where $\hat{\sigma}^{2}$ is the variance of the residuals. The asymptotic distribution of the Kuhn-Tucker estimate follows by employing the standard bootstrapping technique. To arrive at this distribution we proceed as follows:

For a given $X$ and $b_{K T}$

1. Draw a sample for the error term, denoted with $u^{(i)} \sim N\left(0, \hat{\sigma}^{2} I_{T}\right)$

2. Construct a vector of dependent variables $y^{(i)}=X b_{K T}+u^{(i)}$

3. Estimate the model $y^{(i)}=X \beta+u$ subject to the constraints in (7.5) and (7.6)

4. This leads to an estimate $b_{k T}^{(i)}$

5. Repeat steps (1)-(4) 10,000 times. This gives a set $b_{\kappa T}^{(i)} \quad i=1, \ldots, 10000$

These 10.000 values represent the asymptotic distribution of the Kuhn-Tucker estimator.

\subsection{Data}

To illustrate the usefulness of our approach we consider a sample of 304 UK equity mutual funds for the 1991-1999 period, a total of 108 months. These funds are classified into four different investment objectives, based on the FT Unit Trust Yearbook. This enables us to check their style consistency. From the 304 individual mutual funds we calculate 6 equally weighted portfolios, which will be analyzed in more depth. We calculate an equally weighted portfolio containing all 304 funds, an equally weighted portfolio of funds that did not survive during the whole sample period (dead funds), and equally weighted portfolios of mutual funds within a particular investment objective (growth/income, income, growth and small cap).

As we only consider domestic equity funds, the relevant style benchmarks are all UK indices. We include a UK value index (the MSCI UK Value index), a UK growth index (MSCI UK Growth index), a UK small cap index (FT small cap UK index) and two fixed interest classes, cash (the 1-month inter-bank rate) and bonds (the JPM UK Government Bond index). This results in a 5-factor model, which is used to determine a fund's asset mix. Summary statistics on the different equally weighted portfolios (panel A) and benchmarks (panel B) are provided in table 7.1.

It appears that funds focusing on smaller companies delivered the highest performance $(15.56 \%)$ during the sample period. This however is also associated with the highest standard deviation $(15.23 \%)$. Note that over $30 \%$ of the funds in our sample did not survive during the entire period. Because these funds under-performed the average fund by about $2.2 \%$ a severe 
survivorship bias could arise if they were excluded. In our subsequent analysis we therefore consider this dead funds portfolio in more detail.

Table 7.1: Summary statistics, 1991-1999

Panel A: Mutual fund returns

\begin{tabular}{llcc}
\hline Investment objective & $\begin{array}{l}\text { Mean } \\
\text { Return }\end{array}$ & $\begin{array}{c}\text { Standard } \\
\text { Deviation }\end{array}$ & $\begin{array}{c}\text { Number of } \\
\text { funds }\end{array}$ \\
\hline Growth/Income & 12.89 & 12.91 & 79 \\
Income & 12.83 & 12.58 & 72 \\
Growth & 14.02 & 13.23 & 102 \\
Small caps & 15.56 & 15.23 & 51 \\
\hline All funds & 13.76 & 12.78 & 304 \\
Dead funds & 11.55 & 12.65 & 94 \\
\hline
\end{tabular}

Panel B: Benchmark returns

\begin{tabular}{|c|c|c|c|c|c|c|c|}
\hline \multirow[b]{2}{*}{ Benchmark } & \multirow[b]{2}{*}{$\begin{array}{l}\text { Mean } \\
\text { Return }\end{array}$} & \multirow[b]{2}{*}{$\begin{array}{l}\text { Standard } \\
\text { deviation }\end{array}$} & \multicolumn{5}{|c|}{ Cross correlations } \\
\hline & & & Value & Growth & $\begin{array}{c}\text { Small } \\
\text { cap }\end{array}$ & Cash & Bond \\
\hline MSCI Value UK & 14.61 & 14.36 & 1.00 & & & & \\
\hline MSCI Growth UK & 13.91 & 13.66 & 0.79 & 1.00 & & & \\
\hline FT small cap UK & 12.49 & 14.91 & 0.73 & 0.60 & 1.00 & & \\
\hline 1 month inter-bank & 7.04 & 0.53 & -0.11 & 0.02 & -0.17 & 1.00 & \\
\hline JPM UK Gov Bond & 10.51 & 5.94 & 0.44 & 0.48 & 0.26 & 0.17 & 1.00 \\
\hline \multicolumn{8}{|c|}{$\begin{array}{l}\text { Notes: This table provides summary statistics on the UK mutual funds (Panel A) and benchmarks (Panel B) that are } \\
\text { used to perform the Sharpe asset class factor model. Panel A reports annualized total returns with corresponding } \\
\text { standard deviations for six equally weighted portfolios of funds. Used are a portfolio consisting of all } 304 \text { funds, one } \\
\text { with funds that did not survive during the whole sample period and } 4 \text { equally weighted portfolios of mutual funds } \\
\text { within a particular investment objective. Panel B reports returns and standard deviations on the benchmarks that are } \\
\text { used. Finally, cross correlations between the benchmarks are given in Panel B columns } 4 \text { through } 8 \text {. }\end{array}$} \\
\hline
\end{tabular}

\subsection{Results}

In the empirical application we estimate Sharpe's model for the six equally weighted portfolios that have been introduced in the previous section. In addition we determine the asymptotic distribution for the style weights. In our analysis we focus on the added value of the extra information available in the asymptotic distribution of the parameter estimates. Where applicable we compare the results based on point estimates only with the results that also incorporate the information in the asymptotic distribution.

This distribution is applied to perform a series of tests. First, we concentrate our efforts on the preciseness and significance of the style weights (table 7.2). Second, we check 
whether specific factor loadings are significantly different from each other (table 7.3). Third, we test for misclassification (table 7.4). This answers the question whether a fund with a particular objective actually is for the largest part invested in the correct style.

\section{Table 7.2: Results Sharpe asset class factor model}

Panel A: Estimated style weights

\begin{tabular}{|c|c|c|c|c|c|c|c|}
\hline Objective & Alpha & Value & Growth & Small cap & Cash & Bond & $\mathrm{R}^{2}$ \\
\hline Growth/Income & -0.89 & $0.41^{607}$ & $0.34^{\mathrm{vor}}$ & $0.23^{\mathrm{mom}}$ & 0.00 & 0.03 & 0.97 \\
\hline Income & -0.71 & $0.46^{\cdots}$ & $0.18^{\cdots *}$ & $0.27^{* *}$ & 0.00 & $0.09^{* *}$ & 0.96 \\
\hline Growth & 0.46 & $0.27^{* * *}$ & $0.35^{\circ *}$ & $0.38^{\cdots *}$ & 0.00 & 0.00 & 0.97 \\
\hline Small cap & $3.20^{\circ *}$ & 0.00 & 0.00 & $0.98^{* \cdots}$ & 0.02 & 0.00 & 0.91 \\
\hline All funds & 0.39 & $0.27^{676}$ & $0.26^{\prime \prime \prime}$ & $0.44^{m}$ & 0.00 & 0.03 & 0.97 \\
\hline Dead funds & -0.87 & $0.35^{\cdots *}$ & $0.25^{\cdots \cdots}$ & $0.36^{* *}$ & 0.02 & 0.02 & 0.96 \\
\hline
\end{tabular}

Panel B: $95 \%$ Confidence intervals for style weights

\begin{tabular}{|c|c|c|c|c|c|}
\hline Objective & Value & Growth & Small cap & Cash & Bond \\
\hline Growth/Income & {$[0.35-0.47]$} & {$[0.28-0.39]$} & {$[0.18-0.27]$} & {$[0.00-0.03]$} & {$[0.00-0.05]$} \\
\hline Income & {$[0.40-0.52]$} & {$[0.12-0.24]$} & {$[0.22-0.31]$} & {$[0.00-0.03]$} & {$[0.04-0.13]$} \\
\hline Growth & {$[0.21-0.34]$} & {$[0.29-0.39]$} & {$[0.34-0.43]$} & {$[0.00-0.00]$} & {$[0.00-0.00]$} \\
\hline Small cap & {$[0.00-0.00]$} & {$[0.00-0.00]$} & {$[0.96-1.00]$} & {$[0.00-0.04]$} & {$[0.00-0.00]$} \\
\hline All funds & {$[0.22-0.32]$} & {$[0.21-0.31]$} & {$[0.40-0.47]$} & {$[0.00-0.04]$} & {$[0.00-0.06]$} \\
\hline Dead funds & {$[0.29-0.41]$} & {$[0.20-0.31]$} & {$[0.31-0.40]$} & {$[0.00-0.06]$} & {$[0.00-0.06]$} \\
\hline $\begin{array}{l}\text { Notes: This table } \\
\text { portfolios of funds. } \\
\text { objective, where the } \\
\text { (annualized) } \alpha \text { of th } \\
\text { the return on the pa } \\
\text { Because of the const } \\
\text { Significan } \\
\text { Significantly differ } \\
\text { Significantly differ } \\
\text { With significance in }\end{array}$ & $\begin{array}{l}\text { lements in colun } \\
\text { regression is repo } \\
\text { ive portfolio. Pan } \\
\text { ints on the parame } \\
\text { different from z } \\
\text { it from zero at the } \\
\text { it from zero at the } \\
\text { anel A based on } \mathrm{c}\end{array}$ & $\begin{array}{l}\text { ns } 3 \text { to } 7 \text { report } \\
\text { ted, which quanti } \\
\text { I B reports the } 9 \\
\text { ers these have ber } \\
\text { ro at the } 1 \% \text { level } \\
\% \text { level } \\
0 \% \text { level } \\
\text { nfidence intervals }\end{array}$ & $\begin{array}{l}\text { estimated sty } \\
\text { the systematic } \\
\text { confidence in } \\
\text { constructed by }\end{array}$ & $\begin{array}{l}\text { veights. In the } \\
\text { ference betwee } \\
\text { als for all esti } \\
\text { strapping. }\end{array}$ & $\begin{array}{l}\text { ond column the } \\
\text { fund return and } \\
\text { d style weights. }\end{array}$ \\
\hline
\end{tabular}

Table 7.2 presents the parameter estimates of Sharpe's model for six different equally weighted portfolios. In panel A estimated style weights are given. Each row deals with one particular investment objective, where the elements in columns 3 to 7 report the estimated style weights. In the second column the $\alpha$ of the regression is reported, which quantifies the systematic difference between the fund return and the return on the passive portfolio.

Interpreting the estimated weights as an approximation of portfolio holdings makes it possible to check whether funds adhere to their stated investment objective. We find that income funds are mainly exposed to the value benchmark, growth funds to the growth 
benchmark and finally small cap funds are up to $98 \%$ exposed to the smaller companies benchmark. It seems that mutual funds invest as they are supposed to do.

In panel B 95\% confidence intervals are given for all factor loadings. Recall that because of the constraints on the parameters, we have made use of bootstrapping to arrive at confidence intervals for the factor loadings. Because of the constraints on the parameters the asymptotic distribution may be non-normal which makes that the common t-test is often not applicable. The confidence intervals show that the point estimates are relatively precise reflections of the portfolio weights.

In table 7.3 we deal with the question whether two style weights are significantly different from each other. Note that based on the point estimates in table 7.2 it is impossible to carry out such a test. For each equally weighted portfolio we compare all five factor loadings with each other. This leads to 10 comparisons per equally weighted portfolio. We examine whether the difference between two style weights is significantly different from zero. The distribution of the differences follows directly from bootstrapping. Using a simple p-test we then determine whether this difference is statistically different from zero.

Given are the mean difference (column 4), the p-value for the hypothesis that this mean is equal to zero (column 5) and whether the mean is significantly different from zero at the $5 \%$ level (column 6 ). From the results it appears that exposures towards the cash and bond index often are not significantly different from each other. If we turn back to our earlier observations on style adherence it still seems that most funds closely follow their style. For instance, income funds have a value weight that is significantly larger than their growth and/or small cap weight. The only exception to this is the growth exposure for the growth funds, which is not significantly different from the value and/or small cap exposure.

The analysis on the equally weighted portfolios as provided in table 7.2 and 7.3 does not produce evidence of serious style deviations by mutual fund managers. It may be the case that the construction of equally weighted portfolios averages out effects that are present in individual funds. Next, we therefore consider the mutual fund misclassification phenomenon by analyzing the historic returns of all individual mutual funds.

We assume that a growth/income fund should predominantly be exposed to the growth or value benchmark, income funds to the value benchmark, growth funds to the growth benchmark and finally small cap funds to the small cap benchmark. If a fund exhibits a higher weight on any other benchmark, we consider it to be misclassified. ${ }^{62}$ In table 7.4 we summarize the results of this exercise. In column 2 we base our results solely on the point estimates for the factor loadings, in column 3 we also take into account the information in the asymptotic distribution function. On average $27 \%$ of all funds is predominantly exposed to a benchmark other than the one we would expect it to be exposed to. Especially growth funds tend to be misclassified whereas small cap funds adhere to their style for $100 \%$. These results

\footnotetext{
${ }^{62}$ This criterion solely serves as an example and is not meant to be objective in any way.
} 
Table 7.3: Significance for differences between estimated Sharpe style weights

\begin{tabular}{|c|c|c|c|c|c|c|}
\hline Objective & Index 1 & Index 2 & Mean difference & P-value for mean $=0$ & \multicolumn{2}{|c|}{ Significant? } \\
\hline Growth/lncome & Value & Growth & 0.070 & 0.082 & No & \\
\hline Girowth/ncome & Value & Small cap & 0.185 & 0.000 & & YES \\
\hline Growth/nocome & Value & Cash & 0.408 & 0.000 & & YES \\
\hline Growth/ncome & Value & Bond & 0.388 & 0.000 & & VES \\
\hline Growth/ncome & Growth & Small cap & 0.115 & 0.001 & & YES \\
\hline Growth/Income & Growth & Cash & 0.338 & 0.000 & & YES \\
\hline Growth/ncome & Growth & Bond & 0.318 & 0.000 & & VES \\
\hline Growth/lncome & Small cap & Cash & 0.223 & 0.000 & & YES \\
\hline Growth/ncome & Small cap & Bond & 0.203 & 0.000 & & VES \\
\hline Growth/ncome & Cash & Bond & -0.020 & 0.892 & NO & \\
\hline Income & Value & Growth & 0.281 & 0.000 & & YES \\
\hline Income & Value & Small cap & 0.194 & 0.000 & & YES \\
\hline Income & Value & Cash & 0.459 & 0.000 & & VES \\
\hline Income & Value & Bond & 0.374 & 0.000 & & YES \\
\hline Income & Growth & Small cap & -0.087 & 0.986 & & YES \\
\hline Income & Growth & Cash & 0.179 & 0.000 & & YES \\
\hline Income & Growth & Bond & 0.093 & 0.020 & & YES \\
\hline Income & Small cap & Cash & 0.265 & 0.000 & & YES \\
\hline Income & Small cap & Bond & 0.180 & 0.000 & & YES \\
\hline Income & Cash & Bond & -0.086 & 0.012 & & YES \\
\hline Growth & Value & Growth & -0.072 & 0.903 & No & \\
\hline Growth & Value & Small cap & -0.109 & 0.013 & & YES \\
\hline Growth & Value & Cash & 0.272 & 0.000 & & YES \\
\hline Growth & Value & Bond & 0.272 & 0.000 & & YES \\
\hline Growth & Growth & Small cap & -0.037 & 0.827 & NO & \\
\hline Growth & Growth & Cash & 0.345 & 0.000 & & YES \\
\hline Growth & Growth & Bond & 0.345 & 0.000 & & YES \\
\hline Growth & Small cap & Cash & 0.382 & 0.000 & & YES \\
\hline Growth & Small cap & Bond & 0.381 & 0.000 & & YES \\
\hline Growth & Cash & Bond & 0.000 & 0.802 & No & \\
\hline Small cap & Value & Growth & 0.000 & 0.074 & NO & \\
\hline Small cap & Value & Small cap & -0.985 & 0.000 & & YES \\
\hline Small cap & Value & Cash & -0.015 & 0.915 & NO & \\
\hline Small cap & Value & Bond & 0.000 & 0.117 & No & \\
\hline Small cap & Growth & Small cap & -0.985 & 0.000 & & YES \\
\hline Small cap & Growth & Cash & -0.015 & 0.012 & & YES \\
\hline Small cap & Growth & Bond & 0.000 & 0.100 & NO & \\
\hline Small cap & Small cap & Cash & 0.970 & 0.000 & & YES \\
\hline Small cap & Small cap & Bond & 0.985 & 0.000 & & YES \\
\hline Small cap & Cash & Bond & 0.015 & 0.026 & & VES \\
\hline All Funds & Value & Growth & 0.004 & 0.459 & NO & \\
\hline All Funds & Value & Small cap & -0.167 & 0.000 & & YES \\
\hline All Funds & Value & Cash & 0.263 & 0.000 & & YES \\
\hline All Funds & Value & Bond & 0.241 & 0.000 & & YES \\
\hline All Funds & Growth & Small cap & -0.172 & 0.000 & & YES \\
\hline All Funds & Growth & Cash & 0.258 & 0.000 & & YES \\
\hline All Funds & Growth & Bond & 0.236 & 0.000 & & YES \\
\hline All Funds & Small cap & Cash & 0.430 & 0.000 & & YES \\
\hline All Funds & Small cap & Bond & 0.408 & 0.000 & & YES \\
\hline All Funds & Cash & Bond & -0.022 & 0.838 & No & \\
\hline Dead Funds & Value & Growth & 0.093 & 0.045 & NO & \\
\hline Dead Funds & Value & Small cap & -0.006 & 0.554 & NO & \\
\hline Dead Funds & Value & Cash & 0.333 & 0.000 & & YES \\
\hline Dead Funds & Value & Bond & 0.324 & 0.000 & & YES \\
\hline Dead Funds & Growth & Small cap & -0.100 & 0.004 & & YES \\
\hline Dead Funds & Growth & Cash & 0.240 & 0.000 & & YES \\
\hline Dead Funds & Growth & Bond & 0.231 & 0.000 & & YES \\
\hline Dead Funds & Small cap & Cash & 0.339 & 0.000 & & YES \\
\hline Dead Funds & Small cap & Bond & 0.331 & 0.000 & & YES \\
\hline Dead Funds & Cash & Bond & -0.009 & 0.595 & NO & \\
\hline
\end{tabular}

Notes: This table addresses the question whether two style weights are significantly different from each other by examining whether the difference between two weights is significantly different from zero, using a simple p-test. The distribution of the differences follows directly from the results of our bootstrap. Given are the mean differences (column 4), the p-value for the hypothesis that the difference is zero (column 5) and whether the mean is significantly different from zero at the $5 \%$ level (column 6). For each of our equally weighted portfolios of funds we compare all five weights with each other. This leads to 10 comparisons per equally weighted portfolio. 
are in line with for instance DiBartolomeo \& Witkowski (1997) and Kim, Shukla \& Tomas (1999) who found about $30 \%$ of US mutual funds to be misclassified.

These observations however are based on the point estimates of style weights only and therefore do not incorporate estimation error. To test whether funds are significantly misclassified, we again examine the difference between style weights using the asymptotic distribution. The result of this exercise is summarized in column 3. If we take into account the significance of estimated style weights it seems that only $15 \%$ of all funds is misclassified, about half of the percentage we observed without taking into account significance levels. Dead funds are persistently misclassified $(22 \%)$, even if we take into account the significance of style deviations.

Table 7.4: Mutual fund misclassifications based on individual fund returns

\begin{tabular}{lcc}
\hline Objective & $\begin{array}{l}\% \text { Misclassifications } \\
\text { Misclassifications }\end{array}$ \\
\hline Growth/Income & $12 \%$ & $7 \%$ \\
Income & $19 \%$ & $10 \%$ \\
Growth & $58 \%$ & $32 \%$ \\
Small Cap & $0 \%$ & $0 \%$ \\
\hline All Funds & $27 \%$ & $15 \%$ \\
Dead Funds & $31 \%$ & $22 \%$ \\
\hline Notes: This table presents evidence of fund misclassification using individual fund returns. We assume that a \\
growth/income fund should predominantly be exposed to the growth or value benchmark, income finds to the \\
value benchmark, growth funds to the growth benchmark and finally small cap funds to the small cap \\
benchmark. If a fund exhibits a higher weight on any other benchmark, we consider it to be misclassified. \\
Column 2 reports the percentage of misclassified funds per investment objective, solely based on the point \\
estimates for style weights. In column 3 we take into account the significance of estimated style weights and \\
report the percentage of significantly misclassified funds per investment objective.
\end{tabular}

Possible reasons to deviate from a stated investment style include objective gaming or simply negligence. Especially the first, objective gaming, has gained widespread attention among investment professionals. Consider a fund that states to be in a lower risk class than it actually pursues. Using this strategy, the fund manager may be expected to perform better in comparison to the funds in his stated objective group. This obviously exposes its investors to a much higher risk-level than they are aware of. To avoid this, techniques to measure and analyze mutual fund styles are of paramount importance.

To examine this possible source of misclassifications we consider the differences in return between misclassified funds, and funds that are properly classified. We investigate whether misclassified funds deviate from their stated investment objective to out-perform relative to their peers. 
The evidence in table 7.5 Panel A does not suggest that misclassified funds successfully game their objectives to earn higher returns, relative to their peers. ${ }^{63}$ On average the performance of misclassified funds is $0.58 \%$ lower than the return on well-classified funds. If we take the significance of estimated style weights into account, leading to a different set of misclassified funds, panel B arises. Again it appears that misclassified funds under-perform well-classified funds. ${ }^{64}$ Surprisingly misclassified dead funds significantly under-perform their wellclassified peers by $2.09 \%$ per year.

Table 7.5: Objective Gaming

Panel A: Without Confidence intervals

\begin{tabular}{lccc}
\hline Objective & $\begin{array}{c}\text { Return } \\
\text { Misclassified }\end{array}$ & $\begin{array}{c}\text { Return } \\
\text { Well-classified }\end{array}$ & $\begin{array}{c}\text { Difference } \\
\text { (Miss-Well) }\end{array}$ \\
\hline Growth/Income & 11.76 & 13.04 & -1.28 \\
Income & 12.64 & 12.87 & -0.24 \\
Growth & 13.76 & 14.33 & -0.57 \\
Small Cap & -- & 15.56 & 0.00 \\
\hline All Funds & 13.31 & 13.89 & -0.58 \\
Dead Funds & 10.91 & 11.77 & -0.86 \\
\hline
\end{tabular}

Panel B: With Confidence intervals

\begin{tabular}{|c|c|c|c|}
\hline Objective & $\begin{array}{c}\text { Return } \\
\text { Misclassified }\end{array}$ & $\begin{array}{c}\text { Return } \\
\text { Well-classified }\end{array}$ & $\begin{array}{c}\text { Difference } \\
\text { (Miss-Well) }\end{array}$ \\
\hline Growth/Income & 11.18 & 13.07 & -1.89 \\
\hline Income & 12.68 & 12.86 & -0.18 \\
\hline Growth & 13.31 & 13.85 & -0.54 \\
\hline Small Cap & - & 15.56 & 0.00 \\
\hline All Funds & 12.89 & 13.89 & -1.00 \\
\hline Dead Funds & 10.58 & 12.67 & $-2.09^{* *}$ \\
\hline \multicolumn{4}{|c|}{$\begin{array}{l}\text { Notes: In this table we examine whether funds that are misclassified out-perform the } \\
\text { peers, in other words does objective gaming pay? As before, we assume that } \\
\text { growth/income fund should predominantly be exposed to the growth or value benchmarh } \\
\text { income funds to the value benchmark, growth funds to the growth benchmark and finall } \\
\text { small cap funds to the small cap benchmark. If a fund exhibits a higher weight on any othe } \\
\text { benchmark, we consider it to be misclassified. In Panel A column } 4 \text { the (annualized } \\
\text { difference in return between misclassified and well-classified funds is reported pe } \\
\text { investment objective. Note that here only the point estimates of style weights ar } \\
\text { considered in detecting misclassified funds. Panel B takes the significance of estimate } \\
\text { style weights into account when forming the misclassified group and then similarly repor } \\
\text { annual return differences in column } 4 \text {. } \\
\text { Significant at the } 5 \% \text { level }\end{array}$} \\
\hline
\end{tabular}

\footnotetext{
${ }^{63}$ The inability of misclassified funds to out-perform as a group is in line with for instance Ippolito (1992)

${ }^{4}$ Because dead funds have a high probability to be misclassified (according to table 7.5) it could be that this result is mainly driven by the lower return on dead funds. To test this we deleted the dead funds from the analysis and again examined the difference in return between misclassified and well-classified funds. This however does not significantly influence the results, as misclassified still under-perform wellclassified funds by $0.51 \%$ (based on point estimates only) or $0.78 \%$ (taking into account the significance of style weights).
} 


\subsection{Robustness Tests}

In this section we employ several robustness tests to investigate the sensitivity of our main conclusions. These tests focus on benchmark sensitivity, sub-samples and econometric technique. We ran the same tests as in the previous section and below we will touch upon the most important findings. ${ }^{65}$

As mentioned already in section 7.2 , one should pay close attention to the benchmark choice in setting up a Sharpe asset class factor model. Especially the correlation coefficient between benchmarks should not be too high. As the value and growth benchmarks show a correlation of 0.79 , this may cause problems. To assess the influence of this choice on our results we replace both the MSCI value and growth benchmark by the IIA value and growth benchmarks, which are available from Independence International Associates, Inc. (IIA) in Boston. These benchmarks have a correlation coefficient which is considerably lower at 0.58 , and have been constructed by selecting the top and bottom $25 \%$ of market capitalization based on book-to-market. The two different indices are more distinctive from each other compared to the MSCI indices, which have been constructed by selecting the top and bottom $50 \%$.

The use of these indices does not have any impact on most of our fund categories, except for growth funds, which we wiff consider in some more detail hereafter. Growth funds now show a higher exposure to the value benchmark $(0.31)$ and a lower exposure to the growth benchmark $(0.27)$. Apparently growth fund managers have been investing in stocks with high book-to-market stocks, which are more 'value'-like than 'growth'-like. This investment strategy becomes more clearly visible when using benchmarks that are more extreme.

The results using these less correlated indices also reveal a higher percentage of significantly misclassified funds, which rises from $32 \%$ to $52 \%$. Based on point estimates alone the percentage misclassified funds rises from $58 \%$ to $89 \%$. This is yet another example where the use of statistical tests on the portfolio weights plays an important role. Point estimates alone overstate the sensitivity for alternative benchmarks. Our overall conclusions on the reduction of significantly misclassified funds and objective gaming remain unchanged.

As a second robustness check we divide our sample period into two equal periods to investigate the consistency of our previous observations. The first sub-period runs from January 1991 - June 1995, the second sub-period from July 1995 - December 1999. Going from period 1 to period 2, for both value and growth funds the exposure to the value benchmark decreases and the exposure to the growth benchmark increases. Based on point estimates alone this results in an increase of misclassified income funds and a decrease in the misclassified growth funds. Both periods however witness a sharp decrease in

\footnotetext{
As All results are available from the authors upon request.
} 
misclassifications if the asymptotic distribution is introduced. Because the sub-periods contain less observations the confidence intervals are larger reflecting the reduction in information.

Our final robustness check concentrates on the econometric technique to arrive at the asymptotic distribution of the parameter estimates. Judge and Takayama (1966) have shown that it is very difficult to obtain the correct distribution when there are inequality restrictions on the parameters. Standard bootstrapping methods are not necessarily valid when some true parameters are on the boundary. Kim, Stone and White (2000) apply some new results based on Andrews $(1997,1999)$ to arrive at the correct distribution. In order to investigate the influence of this on our results we employ the techniques as given in their paper.

While the point estimates obviously remain the same most confidence intervals get a little bit tighter, especially for the cash and bond benchmark. The use of an alternative econometric method has only minor impact on the reported figures. Moreover, all main conclusions remain valid after applying the alternative methodology.

\subsection{Summary and Conclusions}

In this chapter we have presented a technique to assess the statistical properties of results obtained from return-based style analysis. Because traditional return-based style analysis imposes two constraints on the estimated coefficients, this is not a straightforward exercise. We employ the estimation algorithm introduced by Kuhn-Tucker to arrive at the asymptotic distribution function for the estimated style weights. In traditional approaches style analysis only focuses on the point estimates of the style weights. The asymptotic distribution function allows us to infer confidence intervals for the style coefficients, and to carry out statistical tests on the parameters.

This information is useful for three main reasons: (1) to assess the preciseness of estimated style coefficients (2) to test whether coefficients are significantly different from zero and (3) to determine whether style coefficients are significantly different from each other. This extra information has important practical implications for the fund misclassification phenomenon. Incorporating the asymptotic distribution of style weights provides a better picture on misclassified funds and allows for more elaborate statistical analysis.

To illustrate these three main improvements, and to exemplify the application with respect to the fund misclassification phenomenon, we consider a sample of 304 UK equity mutual funds. This yields four interesting results. First, the Kuhn-Tucker approach enables us to distinguish between style coefficients in a statistically meaningful way. Secondly, the number of misclassified funds decreases by about $50 \%$ if the statistical significance of these style deviations is taken into account, in comparison to the case where the analysis is solely based on point estimates of the portfolio weights. Thirdly, it appears that funds are not gaming 
their objective to out-perform relative to their peers, as misclassified funds on average underperform well-classified funds. Finally we provide some new evidence on the impact of survivorship bias on the fund misclassification phenomenon. As dead funds are persistently misclassified, leaving them out would under-estimate the number of misclassified funds. At the same time the misclassified dead funds significantly under-perform their well-classified peers by $2.09 \%$ per year. Excluding them would consequently over-estimate the return on gaming strategies. Prior studies in this field therefore might be biased in two ways, if only surviving funds were used.

\section{Appendix 7A:}

\section{Notation}

Recall the model that was set-up in section 7.3 is of the form

$$
\begin{aligned}
& r_{i l}=\alpha_{i}+\sum_{j=1}^{N} \beta_{i} I_{n}+\varepsilon_{i} \quad t=1, \ldots, T \\
& \sum_{j=1}^{N} \beta_{i j}=1 \\
& \beta_{i j} \geq 0 \quad j=1, \ldots, N
\end{aligned}
$$

In matrix notation this model is given by

$$
\begin{aligned}
& Y=X \beta+u \\
& j^{\prime} \beta=1 \\
& \beta_{k} \geq 0 \quad k=2, \ldots, K
\end{aligned}
$$

where

$$
\begin{aligned}
Y & =\left(\begin{array}{c}
r_{i 1} \\
\vdots \\
r_{i T}
\end{array}\right) \\
X & =\left(\begin{array}{cccc}
1 & I_{11} & \cdots & I_{N 1} \\
\vdots & \vdots & & \vdots \\
1 & I_{1 T} & \cdots & I_{N T}
\end{array}\right) \\
\beta & =\left(\begin{array}{c}
\alpha_{i} \\
\beta_{i 1} \\
\vdots \\
\beta_{i N}
\end{array}\right)
\end{aligned}
$$

and

$$
j^{\prime}=\left(\begin{array}{llll}
0 & 1 & \cdots & 1
\end{array}\right)
$$


The dimensions are for $\mathrm{Y}(T \times 1)$, for $\mathrm{X}(T \times K)$, for $\mathrm{b}(K \times 1)$, for $j(K \times 1)$ and for $\mathrm{u}(T \times 1)$. For notational convenience the subscript $\mathrm{i}$ has been suppressed. In the following we first show the estimation results for the unconstrained model, then for the Lagrange model in which we also take account for the equality constraint, and finally the model with both equality and inequality constraints is tackled. We show that the Lagrange estimator $\left(b_{L}\right)$ can be written in terms of the unconstrained estimator $\left(b_{V}\right)$, and that the Kuhn-Tucker estimator $\left(b_{K T}\right)$ can be written in terms of the Lagrange estimator (and therefore also in terms of the unconstrained estimator).

\section{Unconstrained model}

The unconstrained estimator minimizes the sum of squares in equation $(4 \mathrm{~A})$ and is given by

$$
b_{U}=\left(X^{\prime} X\right)^{-1} X^{\prime} Y
$$

and the asymptotic distribution of the parameter estimates is given by

$$
b_{v} \sim N\left(\beta, V_{b u}\right)
$$

\section{Lagrange model}

The Lagrange estimator minimizes the sum of squares in equation (4A) subject to the equality constraint in equation $(5 \mathrm{~A})$ and is given by

$$
b_{L}=\left(I_{K}-P j^{j}\right) b_{U}+P
$$

where $I_{K}$ is the $(K \times K)$ identity matrix and the matrix $\mathrm{P}$ is given by

$$
P=\left(X^{\prime} X\right)^{-1} j\left[j^{\prime}\left(X^{\prime} X\right)^{-1} j\right]^{-1}
$$

Proof:

The Lagrangian is given by

$$
L=(Y-X \beta)(Y-X \beta)-\lambda\left(j^{\prime} \beta-1\right)
$$

where $\lambda$ denotes the Lagrange multiplier. The first order condition reads

$$
\frac{\partial L}{\partial \beta}=0: \quad-2 X^{\prime}(Y-X \beta)-j \lambda=0
$$

So, it follows that

$b_{L}=\left(X^{\prime} X\right)^{-1} X^{\prime} Y+\frac{1}{2}\left(X^{\prime} X\right)^{-1} j \lambda=b_{U}+\frac{1}{2}\left(X^{\prime} X\right)^{-1} j \lambda$

From $(5 \mathrm{~A})$ it follows that

$1=t b_{L}=t b_{U}+\frac{1}{2} j^{\prime}\left(X^{\prime} X\right)^{-1} j \lambda$

which implies that

$\lambda=2\left[j^{\prime}\left(X^{\prime} X\right)^{-1} j\right]^{-1}\left(1-j^{\prime} b_{U}\right)$

Substitution of (19A) in (17A) leads to the estimator in (13A). 


\section{Kuhn-Tucker model}

The Kuhn-Tucker model minimizes the sum of squares in equation (4A) subject both to the equality constraint in $(5 \mathrm{~A})$ and the inequality constraints in $(6 \mathrm{~A})$. The most straightforward solution to a Kuhn-Tucker problem is to consider it as $2^{K}$ Lagrange sub-problems, in which the sum of squares is minimized subject to each possible combination for which the inequality constraint is either binding or non-binding. The Lagrange sub-problem that leads to the parameter estimates with the lowest sum of squares and that also meets all restrictions also leads to the Kuhn-Tucker estimator.

The Kuhn-Tucker estimator $\left(b_{K T}\right)$ is given by the estimator of all sub-problems $\left(b_{S}\right)$ that minimizes the sum of squares and fulfils all restrictions. Let $\mathrm{S}$ be the matrix that represents the binding inequality constraints, i.e. the associated equality constraint reads

$S \beta=0$

For example, the case where the second and the third parameter are binding is represented by the $(2 \times K)$ matrix

$$
S=\left(\begin{array}{llllll}
0 & 1 & 0 & 0 & \cdots & 0 \\
0 & 0 & 1 & 0 & \cdots & 0
\end{array}\right)
$$

The solution of the sub-problem of minimizing the sum of squares in equation (4A) subject to both the equality constraint in $(6 \mathrm{~A})$ and in $(20 \mathrm{~A})$ is given by

$b_{S}=\left\{I_{\kappa}-V S^{\prime}\left(S V S^{\prime}\right)^{-1} S\right\} P+\left\{I_{\kappa}-V S^{\prime}\left(S V S^{\prime}\right)^{-1} S\right\} I_{K}-P b_{U}$

where

$V=\left(I_{\kappa}-\left(X^{\prime} X\right)^{-1} j\left\{j^{\prime}\left(X^{\prime} X\right)^{-1} j\right\} j^{\prime}\right)\left(X^{\prime} X\right)^{-1}=\left(I_{K}-P j^{\prime}\right)\left(X^{\prime} X\right)^{-1}$

and the associated Kuhn-Tucker estimator reads

$b_{K T}=\min _{s}\left\{\left(Y-X b_{s}\right)\left(Y-X b_{s}\right) \mid j^{\prime} b_{s}=1 ; S b_{s}=0\right\}$

\section{Proof:}

The Lagrangian is given by

$$
L=(Y-X \beta)(Y-X \beta)-\lambda\left(j^{\prime} \beta-1\right)-\mu(S \beta)
$$

where $\lambda$ and $\mu$ denote the Lagrange multipliers. The first order condition reads

$$
\frac{\partial L}{\partial \beta}=0:-2 X^{\prime}(Y-X \beta)-j \lambda-S^{\prime} \mu=0
$$

So, it follows that

$$
b_{S}=b_{v}+\frac{1}{2}\left(X^{\prime} X\right)^{-1} j \lambda+\frac{1}{2}\left(X^{\prime} X\right)^{-1} S^{\prime} \mu
$$

From equation $(5 \mathrm{~A})$ it follows that

$$
1=j^{\prime} b_{s}=j^{\prime} b_{t}+\frac{1}{2}\left\{j^{\prime}\left(X^{\prime} X\right)^{-1} j\right\}+\frac{1}{2} j^{\prime}\left(X^{\prime} X\right)^{-1} S^{\prime} \mu
$$

Solving for $\lambda$ gives 
$\lambda=2\left[j^{-}\left(X^{\prime} X\right)^{-1} j\right]^{-1}\left(1-j^{\prime} b_{U}\right)-\left[j^{\prime}\left(X^{\prime} X\right)^{-1} j\right]^{-1} j^{-}\left(X^{\prime} X\right)^{-1} s^{\prime} \mu$

Substitution of (29A) in (27A) gives

$b_{S}=b_{L}+\frac{1}{2} V S^{\prime} \mu$

Now, use the relation in equation $(20 \mathrm{~A})$, to arrive at

$0=S b_{S}=S b_{L}+\frac{1}{2}\left(S V S^{\prime}\right) \mu$

Solving for $\mu$ gives

$\mu=-2\left(S V S^{\prime}\right)^{-1} S b_{L}$

Substitution of (32A) in (30A) gives

$b_{s}=\left\{I-V S^{\prime}\left(S V S^{\prime}\right)^{-1} S\right\}_{l}$

Substitution of $(13 \mathrm{~A})$ in (33A) gives the required result. 



\section{Chapter 8}

\section{Summary and Concluding Remarks}

This thesis intended to add to the understanding of the European mutual fund industry. As more and more people are using mutual funds, for instance as a means to take care of their pensions, this is of eminent importance. While the US industry has been studied for over 40 years, little is known about the structure and performance of the European industry. This thesis provides evidence on both issues. These results should be of interest to both private and institutional investors, regulators and of course academics.

Chapter 2 starts with a discussion on the mutual fund concept. After that we analyze the regulatory framework and the associated costs of investing in a mutual funds. The main part of this chapter is however devoted to a qualitative overview of the mutual fund literature. This is done along three lines. First, we present a discussion on the structure of the industry. Second, evidence on mutual fund performance is presented. Third, we analyze the properties of return-based style analysis (RBSA). From this chapter we conclude that there is a general lack of studies on the European mutual fund industry. By using newly collected databases and improved model specifications, this thesis tries to fill this gap.

Chapter 3 provides an analysis of the structure of the European mutual fund industry. Comparing the European structure with the structure in the United States leads to the following conclusions. We find that Europe is still lagging the US mutual fund industry when it comes to total asset size, average fund size, and market importance. Besides these findings we show that the mutual fund markets in the individual European countries are dominated by a few large domestic fund groups, which could possibly lead to lower levels of competition. In our preliminary performance tests we observe five interesting results. First, the European mutual funds have on average a better performance than their American counterparts. This is remarkable, as we know that the levels of competition might be lower in Europe. Theoretically we would assume the opposite. Second, we find a dramatic increase in the 
performance of the German mutual fund sector. Third, we show that the Italian, French, and Dutch mutual funds have a low exposure to their domestic equity benchmark. This exposure however, is rising through time, which indicates that they are increasingly behaving as we expect them to do. Fourth, the results suggest that European index funds are not following pure index strategies. Finally, small cap mutual funds in both Europe and the United States out-perform the benchmark and all other mutual funds. In this market segment mutual funds apparently add more value than their counterparts in the large cap segment.

In chapter 4 a comprehensive assessment of existing mutual fund performance models is presented. Using a survivor-bias free database of all US mutual funds, we explore the added value of introducing extra variables like size, book-to-market, momentum and a bond index. In addition to that we evaluate the use of introducing time-variation in betas and alpha. Our results reveal five major conclusions. First, we document a severe survivorship bias if dead funds are not included in the database. This leads to a significant overestimation of raw returns of $0.51 \%$ and an overestimation of alphas of up to $0.64 \%$ per year. Second, within an unconditional setting we find the 4 -factor model, including market beta, SMB, HML and PRIYR momentum is best able to explain mutual fund returns. Third, conditioning betas on publicly available information proves to be a strong improvement in mutual fund performance measurement. All conditional models are superior to their unconditional peers. Within the conditional setting the 4-factor model is again statistically the strongest model. Fourth, we find only very little evidence of time-variation in fund alphas. Fifth, at the aggregate level, 'all funds portfolio', the alpha estimate does not change that much when going from an unconditional CAPM model to for instance a conditional Carhart model. At the investment style level however, the influence of using a more elaborate model is more significant. 2 out of 4 portfolios exhibit significant under-performance when using the conditional 4-factor model, while using the unconditional CAPM model their performance was indistinguishable from zero.

Chapter 5 investigates mutual fund performance using a survivorship bias controlled sample of 506 funds from the 5 most important mutual fund countries. The latter is done using the Carhart (1997) 4-factor asset-pricing model. In addition we investigate whether European fund managers exhibit "hot hands", persistence in performance. Finally the influence of fund characteristics on risk-adjusted performance is considered. Our overall results suggest that European mutual funds, and especially small cap funds are able to add value, as indicated by their positive after cost alphas. If we add back management fees, 4 out of 5 countries exhibit significant out-performance at an aggregate level. Finally, we detect strong persistence in mean returns for funds investing in the United Kingdom. Our results deviate from most US studies that argue mutual funds under-perform the market by the amount of expenses they charge.

In chapter 6 we review and extend previous research on ethical mutual fund performance, using an international database containing 103 German, UK and US ethical 
mutual funds. By applying a multi-factor Carhart (1997) model we solve the benchmark problem most prior ethical studies suffered from. After controlling for investment style, we find little evidence of significant differences in risk-adjusted returns between ethical and conventional funds for the 1990-2001 period. Introducing time-variation in betas however leads to a significant under-performance of domestic US funds and a significant outperformance of UK ethical funds, relative to their conventional peers. Finally, we differentiate previous results by documenting a learning effect. After a period of strong underperformance, older ethical funds finally are catching up, while younger funds continue to under-perform both the index and conventional peers.

Chapter 7 presents a technique to assess the statistical properties of results obtained from return-based style analysis. Because traditional return-based style analysis imposes two constraints on the estimated coefficients, this is not a straightforward exercise. We employ the estimation algorithm introduced by Kuhn-Tucker and standard bootstrapping to arrive at the asymptotic distribution function for the estimated style weights. In traditional approaches style analysis only focuses on the point estimates of the style weights. The asymptotic distribution function allows us to infer confidence intervals for the style coefficients, and to carry out statistical tests on the parameters. By using a UK sample of equity funds four interesting findings emerge. First, the Kuhn-Tucker approach enables us to distinguish between style coefficients in a statistically meaningful way. Second, the number of misclassified funds decreases by about $50 \%$ if the statistical significance of these style deviations is taken into account, in comparison to the case where the analysis is solely based on point estimates of the portfolio weights. Third, it appears that funds are not gaming their objective to out-perform relative to their peers, as misclassified funds on average underperform well-classified funds. Finally we provide some new evidence on the impact of survivorship bias on the fund misclassification phenomenon. As dead funds are persistently misclassified, leaving them out would under-estimate the number of misclassified funds. At the same time the misclassified dead funds significantly under-perform their well-classified peers by $2.09 \%$ per year. Excluding them would consequently over-estimate the return on gaming strategies. Prior studies in this field therefore might be biased in two ways, if only surviving funds were used. 



\section{References}

ABN AMRO Asset Management, Beleggingsinstellingen 1997, Amsterdam, March 1997

Anderson, E., L.P. Hansen, and T.J. Sargent, Robustness, Detection and the Price of Risk, Working Paper University of North Carolina, University of Chicago and Stanford University, 2000

Andrews, D., Estimation when a Parameter is on a Boundary: Theory and Applications, Discussion Paper Cowles Foundation, Yale, 1997

Andrews, D., Inconsistency of the Bootstrap when a Parameter is on a Boundary, Econometrica 67, 2000, 1341 - 1383

Barberis, N., Investing for the Long Run when Returns are Predictable, Journal of Finance $55,2000,225-264$

Blake, D. and A. Timmermann, Mutual fund Performance: Evidence for the UK, European Finance Review, Vol. 2, 1998, pp. 57-77

Brown, K.C., W.V. Harlow, and L.T. Starks, Of Tournaments and Temptations: An Analysis of Managerial Incentives in the Mutual Fund Industry, Journal of Finance, Vol. 51, 1996, pp. 85-109

Brown, S.J., and W.N. Goetzmann, Performance Persistence, Journal of Finance, Vol. 50, 1995 , pp. $679-698$ , Mutual Fund Styles, Journal of Financial Economics

$43,1997,373-399$

Brown, S., and W. Goetzmann, R. Ibbotson and S. Ross, Survivorship Bias in Performance studies, Review of Financial Studies 5, 1992, 553-580

Carhart, M., On Persistence in Mutual Fund Performance, Journal of Finance, Vol. 52, 1997, pp. $57-82$,

Carhart, M., J. Carpenter, A. Lynch and D. Musto, Mutual Fund Survivorship, Working paper Goldman Sachs Asset Management, 2000

Chan, L.K., N. Jegadeesh and J. Lakonishok, Momentum Strategies, Journal of Finance, Vol. 51, 1996, pp. 1681-1714 
Chen, Z. and P.J. Knez, Portfolio Performance Measurement: Theory and Applications Review of Financial Studies, Vol. 9, 1996, pp. 511-556

Chordia, T., The Structure of Mutual Fund Charges, Journal of Financial Economics 41, 1996, pp. 3-39

Christopherson, J.A., W. Ferson and A. Turner, Performance Evaluation using Conditional Alphas and Betas, Journal of Portfolio Management, Fall 1999, pp. 59-72

Christopherson, J.A., W. Ferson and D. Glasmann, Conditioning Manager Alphas on Economic Information: Another Look at Persistence of Performance, Review of Financial Studies, Vol. 11, 1998, pp. 111-142

Collins, S., and P. Mack, The Optimal Amount of Assets under Management in the Mutual Fund Industry, Financial Analysts Journal, 1997, pp. 67-73

Dahlquist, M., S. Engström, and P. Söderlind, Performance and Characteristics of Swedish Mutual Funds, Journal of Financial and Quantitative Analysis, Vol. 35, 2000, pp. 409. 423

Dermine, D. and L-H Röller, Economies of Scale and Scope in French Mutual Funds, Journal of Financial Intermediation, Vol. 2, 1992, pp. 83-93

DiBartolomeo, D., and E. Witkowski, Mutual Fund Misclassification: Evidence based on Style Analysis, Financial Analysts Journal Sept/Oct, 1997, pp. 32-43

DiBartolomeo, D., Explaining and Controlling The Returns on Socially Screened US Equity Portfolios, Presentation to New York Society of Security Analysts, 1996

Diltz, J.D., Does Social Screening Affect Portfolio Performance?, The Journal of Investing, Spring, 1995, pp. 64-69

Economist, Aux armes, investisseurs, February 13, 83, 1999

Elton, E., M. Gruber, S. Das and M. Hlavka, Efficiency with Costly Information: A Reinterpretation of Evidence from Managed Portfolios, Review of Financial Studies, Vol. 6, 1993, pp. 1-22

Elton, E. and M. Gruber, Common factors in Active and Passive Portfolios, European Finance Review, Vol. 3, 1999, pp. 53-78

Elton, E., M. Gruber, S. Das and C. Blake, The Persistence of Risk-adjusted Mutual Fund Performance, Journal of Business, Vol. 69, 1996, pp. 133-157

Falkenstein, E., Preferences for Stock Characteristics as revealed by Mutual Fund Portfolio Holdings, Journal of Finance, Vol. 51, 1996, pp. 111-135

Fama, E. and K.R. French, The Cross-Section of Expected Stock Returns, Journal of Finance, Vol. 47, 1992, pp. 427-465

, Common Risk Factors in the Returns on Stocks and Bonds, Journal of Financial Economics, Vol. 33, 1993, pp. 3-53

, Multifactor Explanations of Asset Pricing Anomalies, Journal of Finance, Vol. 51, 1996, pp. 55-84 
Féderation Européenne des Fonds et Societés d'Investissement (FEFSI), 1996 Annual Statistics, July 1997

Ferson, W. and R. Schadt, Measuring Fund Strategy and Performance in Changing Economic Conditions, Journal of Finance, Vol. 51, 1996, pp. 425-462

Financial Times Unit Trust Yearbook 1997, Financial Times Publishing, London, 1997

Goetzmann, W., and R. Ibbotson, Do winners repeat? Patterns in mutual fund behavior, Journal of Portfolio Management, Winter, 1994, pp. 9-18

Goldreyer, E.F. and J.D. Diltz, The Performance of Socially Responsible Mutual Funds: Incorporating Sociopolitical Information in Portfolio Selection, Managerial Finance, Vol. 25, No. 1, 1999, pp. 23-36

Gouriéroux, Ch., and A. Montfort, Statistics and Econometric Models, Vol. 2, Cambridge University Press, 1995, 536p

Gouriéroux, Ch., Holly A., and A. Montfort, Likelihood Ratio Test, Wald Test and KuhnTucker Test in Linear Models with Inequality Constraints on the Regression Parameters, Econometrica, Vol. 50, 1982, 63-80

Gregory, A., J. Matatko and R. Luther, Ethical Unit Trust Financial Performance: Small Company Effects and Fund Size Effects, Journal of Business Finance \& Accounting. Vol. 24, No. 5, 1997, pp.705-24

Grinblatt, M., and S. Titman, Mutual Fund Performance: An Analysis of quarterly Portfolio Holdings, Journal of Business, Vol. 62, 1989a, pp. 393-416 , Portfolio Performance Evaluation: Old Issues and New Insights,

Review of Financial Studies, Vol. 2, 1989b, pp. 393-421 , The Persistence of Mutual Fund Performance, Journal of

Finance, Vol. 47, 1992, pp. 1977-1984

Gruber, M., Another Puzzle: The Growth in Actively Managed Mutual Funds, Journal of Finance, Vol. 51, 1996, pp. 783-807

Grünbichler, A., and U. Pleschiutschnig, Performance Persistence: Evidence for the European Mutual Funds Market, Working Paper University of St. Gallen, 1999

Guerard, J.B., Is there a Cost to being Socially Responsible in Investing?, The Journal of Investing, Summer, 1997, pp. 11-18

Hamilton, S., H. Jo and M. Statman, Doing Well While Doing Good? The Investment Performance of Socially Responsible Mutual Funds, Financial Analysts Journal, Vol. 49, No. 6, 1993, pp.62-66

Hendricks, D., J.Patel and R. Zeckhauser, Hot Hands in Mutual Funds: Short-run Persistence of Relative Performance, 1974-1988, Journal of Finance, Vol. 48, 1993, pp. 93-130

Hoppenstedt Fondsführer 1997, Verlag Hoppenstedt, Darmstadt, 1997

Ippolito, R., Efficiency with Costly Information: A Study of Mutual Fund Performance, Quarterly Journal of Economics, Vol. 104, 1989, pp. 1-23 
Jegadeesh, N. and S. Titman, Returns to buying Winners and selling Losers: Implications for Stock Market Efficiency, Journal of Finance, Vol. 48, 1993, pp. 65-91

Jensen, M., The Performance of Mutual Funds in the period 1945-1964, Journal of Finance, Vol. 23, 1968, pp. 389-416

, Risk, the Pricing of Capital Assets and Evaluation of Investment Portfolios, Journal of Business, Vol. 42, 1969, pp. 167-247

Judge, G.G. and T. Takayama, Inequality Restrictions in Regression Analysis, Journal of American Statistical Association 61, 1966, pp. 166-181

Khorana, A. and H. Servaes, The Determinants of Mutual Fund Starts, Review of Financial Studies, Vol. 12, 1999, pp. 1043-1074

Working Paper London Business School, 2001

Kim, M., R. Shukla and M. Tomas, Mutual Fund Objective Misclassification, Journal of Economics and Business 52, 2000, pp. 309-323

Kim, T-H, D. Stone and H. White, Asymptotic and Bayesian Confidence Intervals for Sharpe Style Weights, Discussion Paper No. 00/18 University of Nottingham, 2000

Kodde, D.A., and F.C. Palm, Wald Criteria For Jointly Testing Equality and Inequality Restrictions, Econometrica. Vol. 54, 1986, pp. 1243-1248

Koedijk, C.G., P.C. Schotman, and M. Schweitzer, The Performance of the Dutch Mutual Fund Sector, LIFE working paper, 1998

Kurtz, L., No Effect, or No Net Effects? Studies on Socially Responsible Investing, The Journal of Investing, Winter, 1997, pp. 37-49

Lakonishok, J., A. Shleifer and R. Vishny, Contrarian Investment, Extrapolation and Risk, Journal of Finance, Vol. 49, 1994, pp. 1541-1578

Lehman, B., and D. Modest, Mutual Fund Performance Evaluation: A Comparison of Benchmarks and Benchmark Comparisons, Journal of Finance, Vol. 42, 1987, pp. 233265

Lobosco, A., and D. DiBartolomeo, Approximating the Confidence Intervals for Sharpe Style Weights, Financial Analysts Journal, July/August, 1997, pp. 80-85

Luther, R.G. and J. Matatko, The Performance of Ethical Unit Trusts: Choosing an Appropriate Benchmark', British Accounting Review, Vol. 26, 1994, pp. 77-89

Luther, R.G., J. Matatko and D. Corner, 'The Investment Performance of UK Ethical Unit Trusts', Accounting, Auditing and Accountability Journal, Vol. 5, 1992, pp. 57-70

Maenhout, P., Robust Portfolio Rules and Asset Pricing, INSEAD Working paper, 2000 Malkiel, B., Returns from Investing in Equity Mutual Funds 1971-1991, Journal of Finance, Vol. 50, 1995, pp. 549-573

Mallin, C.A., B. Saadouni and R.J. Briston, The Financial Performance of Ethical Investment Funds, Journal of Business Finance \& Accounting, Vol. 22, 1995, pp. 483-96 
McDonald, J., French Mutual Fund Performance: Evaluation of Internationally-Diversified Portfolios, Journal of Finance, Vol. 28, 1973, pp. 1161-1180

Mueller, D.C., and B. Rauning, Heterogeneities within Industries and Structure-Performance Models, Review of Industrial Organization, Vol 15, 1999, pp. 303-321

Otten, R. and D. Bams, European Mutual Fund Performance, European Financial Management, Vol. 8(1), 2002, pp. 75-101

Pesaran, M. and A. Timmerman, Predictability of Stock Returns: Robustness and Economic Significance, Journal of Finance, Vol. 50, 1995, pp. 1201-1228

Poterba, J.M., S.F. Venti, and D.A. Wise, 401(k) Plans and Future Patterns of Retirement Saving, US Economic Review 88, No. 2., 1998, pp. 179-184

Rouwenhorst, G., International Momentum strategies, Journal of Finance, Vol. 53, 1998, pp. 267-284

Sauer, D.A., The Impact of Social-Responsibility Screens on Investment Performance: Evidence from the Domini 400 Social Index and Domini Equity Mutual Fund, Review of Financial Economics, Vol. 6, No. 2, 1997, pp. 137-149

Scherer, F.M., and D. Ross, Industrial Market Structure and Economic Performance, 1990

Shaffer, S., Structure, Conduct, Performance, and Welfare, Review of Industrial Organization. Vol 9, 1999, pp. 435-450

Sharpe, W.F., Mutual fund performance, Journal of Business, Vol. 39(1), 1966, pp. 119-138 , Determining a Fund's Effective Asset Mix, Investment Management Review, 1988, pp. 59-69

, Asset Allocation: Management Style and Performance Measurement, Journal of Portfolio Management 46, 1992, pp. 7-19,

Shukla, R. and G. van Imwegen, Do Locals Perform better than Foreigners?: An Analysis of UK and US Mutual Fund Managers, Journal of Economics and Business, Vol. 47, 1995, pp. 241-254

Sirri, E.R., and P. Tufano, Costly Search and Mutual Fund Flows, Journal of Finance, Vol. 53,1998 , pp. $1589-1622$

Statman, M., Socially Responsible Mutual Funds, Financial Analysts Journal, May-June, 2000, pp. 30-39

Ter Horst, J., Th. Nijman and F. De Roon, Style Analysis and Performance Evaluation of Dutch Mutual Funds, CentER discussion paper 9850, 1998

Tufano, P., and M. Sevick, Board Structure and Fee-setting in the US Mutual Fund Industry, Journal of Financial Economics 46, 1997, pp. 321-355

Walter, I., The Global Asset Management Industry: Competitive Structure, Conduct, and Performance, Journal of Financial Markets, Institutions and Instruments, 1999

Ward, C. and A. Saunders, UK Unit Trust Performance 1964-1974, Journal of Business Finance \& Accounting, Vol. 3/4, 1976, pp. 83-97 
Wittrock, C. and M. Steiner, Performance-messung ohne Rückgriff auf Kapitalmarkttheoretische Renditeerwatungsmodelle, Kredit und Kapital, 1995, pp. 1-45 Zheng, L., Is Money Smart? A Study of Mutual Fund Investors' Fund Selection Ability, Journal of Finance, Vol. 54, 1999, pp. 901-933 


\section{Nederlandse samenvatting / Dutch summary}

De toegevoegde waarde van dit proefschrift ligt in het vergroten van onze kennis op het gebied van de Europese markt voor beleggingsfondsen. Aangezien steeds meer mensen beleggingsfondsen gebruiken, bijvoorbeeld om hun pensioenvorming gestalte te geven, is dit van eminent belang. Terwijl de beleggingsfondsenmarkt in de Verenigde Staten (VS) reeds meer dan 40 jaar aan onderzoek wordt blootgesteld, is slechts weinig bekend over de structuur en prestaties van de Europese markt voor beleggingsfondsen. Dit proefschrift verzamelt bewijs op beide vlakken. De resultaten hiervan zijn relevant voor particuliere- en institutionele beleggers, wetgevers en uiteraard academici.

In hoofdstuk 2 wordt allereerst het beleggingsfondsconcept uiteengezet. Vervolgens worden de wettelijk kaders en de kosten van beleggingsfondsen belicht. De kern van hoofdstuk 2 wordt echter gevormd door een kwalitatief overzicht van de literatuur op het gebied van beleggingsfondsen. Dit literatuuroverzicht wordt toegespitst op drie thema's. Allereerst belichten we de structuur van de beleggingsfondsenmarkt. Vervolgens de prestaties en tenslotte bespreken we Return-Based Style Analysis (RBSA). De belangrijkste conclusie van dit hoofdstuk is terug te voeren op het ontbreken van gedegen onderzoek naar Europese beleggingsfondsen. Door middel van het verzamelen van nieuwe gegevensbestanden en het toepassen van verbeterde modelspecificaties trachten we deze lacune op te vullen.

Hoofdstuk 3 beschrijft de structuur van de Europese markt voor beleggingsfondsen. Indien we de Europese markt vergelijken met die in de VS komen we tot een aantal verschillende conclusies. De Europese markt loopt nog steeds achter op de Amerikaanse met betrekking tot de totale grootte, gemiddelde fondsgrootte en het belang ten opzichte van de totale aandelenmarkt. Daarnaast tonen we aan dat in de verschillende Europese landen enkele fondsgroepen de markt domineren, wat waarschijnlijk leidt tot lagere onderlinge concurrentie. Met betrekking tot de prestaties van de beleggingsfondsen presenteert hoofdstuk 3 vijf belangrijke conclusies. 1) De Europese fondsen presteren over het algemeen iets beter dan de Amerikaanse, wat vrij opmerkelijk is aangezien we vanwege de grotere concurrentie in de VS het tegenovergestelde zouden verwachten. 2) De prestaties van de Duitse fondsen in ons onderzoek verbeteren sterk door de tijd. 3) Italiaanse, Franse en Duitse fondsen vertonen een 
lage gevoeligheid voor de lokale aandelen index. Deze gevoeligheid neemt echter toe door de tijd, wat aangeeft dat deze fondsen in toenemende mate aan de verwachtingen voldoen. 4) Onze resultaten doen vermoeden dat de Europese index fondsen zich niet aan hun opdracht houden: het volgen van de index. 5) Fondsen die uitsluitend beleggen in kleine ondernemingen presteren beter dan de benchmark index en eveneens beter dan alle andere fondsen. Dit duidt op het vermogen van fondsmanagers om waarde toe te voegen in het geval van kleine ondernemingen, terwijl dit ontbreekt onder de grote ondernemingen.

In hoofdstuk 4 toetsen we de toepasbaarheid van de huidige prestatiemetingmodellen. Door middel van een Amerikaanse database die eveneens fondsen meeneemt die niet meer bestaan, onderzoeken we de toegevoegde waarde van het opnemen van extra variabelen. Onder andere het gebruik van een aanpassing voor de grootte van een onderneming, de boekwaarde ten opzichte van de marktwaarde, momentum en een obligatie index. Bovendien introduceren we tijdsvariatie in de geschatte beta's en alpha's. Onze bevindingen zijn als volgt samen te vatten. Allereerst tonen we aan dat het niet opnemen van fondsen die om welke reden dan ook niet meer bestaan, leidt tot een overschatting van ruwe rendementen van $0.51 \%$ en een overschatting van voor risico gecorrigeerde rendementen (alpha) van $0.64 \%$ per jaar. Vervolgens bleek dat in het on-conditionele geval een 4-factor model met correcties voor de marktindex, ondernemingsgrootte, boek/marktwaarde en momentum de beste verklaringskracht gaf. Het introduceren van tijdsvariatie bleek een belangrijke factor te zijn. Alle conditionele modellen bleken beter te presteren dan de on-conditionele. Dit geeft dus aan dat fonds managers hun beleggingsstijl aanpassen door de tijd, op basis van de conditionele variabelen. De voor risico gecorrigeerde rendementen (alpha) vertoonden daarentegen geen tijdsvariatie. Binnen deze conditionele setting bleek wederom het 4 -factor model het beste in staat om beleggingsfonds rendementen te verklaren. Tenslotte bleek de invloed van het gebruik van de verschillende soorten modellen weinig invloed te hebben op de schatting voor alpha indien we alle fondsen in een portefeuille groepeerden. Wanneer fondsen met dezelfde soort strategie echter bij elkaar in een portefeuille werden gezet bleek in 2 van de 4 gevallen de invloed op alpha wel degelijk van belang te zijn. Het blijkt dus dat het groeperen van alle fondsen, ongeacht hun beleggingsfilosofie, leidt tot het verlies van enige informatie.

De belangrijkste resultaten uit hoofdstuk 4 passen we vervolgens toe in hoofdstuk 5 . Door gebruik te maken van een unieke database bestaande uit de vijf meest belangrijke Europese fondsmarkten toetsen we de prestaties van Europese beleggingsfondsen. Daarnaast bekijken we of de Europese fondsmanagers het zogenaamde "hot hands" effect bezitten. Dat wil zeggen dat managers die in het verleden goed presteerden, dit in de toekomst ook doen. Tenslotte waren we geïnteresseerd in de invloed van fondskarakteristieken op het voor risico gecorrigeerde rendement. Op basis van ons onderzoek naar de algemene prestaties van de fondsen concluderen we dat Europese beleggingsfondsen wel degelijk waarde kunnen toevoegen. In het bijzonder fondsen die in kleine ondernemingen beleggen, zijn in staat om de markt te verslaan, zelfs na aftrek van gemaakte kosten. Wanneer we voor alle fondsen de 
gemaakte kosten buiten beschouwing laten, blijken zelfs in vier van de vijf landen de fondsen de markt significant te verslaan. Tenslotte vertonen de Engelse fondsen een sterke persistentie in hun prestaties. Dat wil zeggen dat een goede fondsmanager in de volgende periode eveneens een bovengemiddelde prestatie neerzet. De resultaten van dit onderzoek naar Europese beleggingsfondsen wijken sterk af van de resultaten op basis van Amerikaanse fondsen. Het lijkt er dus op dat de Europese fondsen, in tegenstelling tot hun Amerikaanse collega's, wel degelijk in staat zijn om waarde toe te voegen voor hun klanten.

Hoofdstuk 6 besteedt aandacht aan een vrij nieuw fenomeen, het zogenaamde duurzaam of ethisch beleggen. Op basis van een internationale database van 103 ethische beleggingsfondsen uit Duitsland, het Verenigd Koninkrijk en de Verenigde Staten meten we de toegevoegde waarde van ethisch beleggen. Alle voorgaande studies op dit gebied worstelden met het probleem van de juiste benchmark keuze. Op basis van onze resultaten in hoofdstuk 4 en 5 trachtten wij dit probleem op te lossen door gebruik te maken van een model met meerdere factoren. Nadat we de prestaties van zowel ethische als niet-ethische fondsen hebben gecorrigeerd voor factoren als ondernemingsgrootte, boek/marktwaarde en momentum lijkt er geen significant verschil te bestaan tussen de twee soorten fondsen. Het lijkt er dus op dat een belegging in een ethisch verantwoord beleggingsfonds niet leidt tot een lager rendement, althans tijdens de door ons onderzochte periode van 1990-2001. Wanneer we echter tijdsvariatie introduceren blijken de Amerikaanse fondsen die slechts in hun eigen land beleggen significant slechter te presteren, terwijl de Engelse fondsen dan juist significant beter presteren. Tenslotte vinden we bewijs voor een zogenaamd leereffect. Terwijl de prestaties van de jonge ethische fondsen duidelijk achterblijven, weten de oudere ethische fondsen de markt te verslaan.

Hoofdstuk 7 presenteert een techniek om de statistische relevantie van de resultaten van Return-Based Style Analysis (RBSA) te bepalen. Aangezien traditionele RBSA twee restricties op de te schatten coefficienten legt, is dit geen eenvoudige exercitie. Om te komen tot de asymptotische verdeling van de geschatte stijl coëfficiënten maken we gebruik van de Kuhn-Tucker optimaliseringstechniek, in combinatie met een standaard bootstrap. Bij een traditionele RBSA wordt slechts gebruik gemaakt van puntschattingen voor de stijl coëfficiënten. Door het bepalen van de asymptotische verdeling kunnen we nu echter eveneens betrouwbaarheidsintervallen afleiden, die ons vervolgens in de gelegenheid stellen om statistische toetsen uit te voeren. Het toepassen van deze techniek op een database met Engelse aandelenfondsen leidt tot een aantal interessante bevindingen. Allereest kunnen we door het gebruik van de Kuhn-Tucker methode de verschillen tussen twee stijl coefficienten aan een statistische toets onderwerpen. Op deze manier blijkt dat we het percentage fondsen dat op basis van traditionele RBSA verkeerd was geclassificeerd met $50 \%$ kunnen terugbrengen indien we de significantie van de afwijkingen incorporeren. Verder blijkt dat de fondsen die volgens de RBSA methode verkeerd zijn geclassificeerd dit niet doen om beter te presteren ten opzichte van de overige fonden in hun eigen beleggingscategorie. Het blijkt 
namelijk dat de fondsen die afwijken van hun opgegeven beleggingsstijl gemiddeld slechter presteren dan de fondsen die zich wel aan hun opdracht houden. Tenslotte levert hoofdstuk 7 nieuw bewijs voor de invloed van survivorship bias, het weglaten van fondsen die niet meer bestaan, op het misclassificatie fenomeen. Aangezien fondsen die niet meer bestaan vaker verkeerd zijn geclassificeerd, zou het het weglaten van deze fondsen leiden tot het te laag inschatten van het aantal verkeerd geclassificeerde fondsen. Daarnaast presteren verkeerd geclassificeerde fondsen $2.09 \%$ per jaar significant slechter dan juist geclassificeerde fondsen. Het weglaten van deze fondsen zou dus leiden tot het overschatten van de rendementen van strategieèn die afwijken van de opdracht teneinde een hogere relatieve rangschikking te bereiken. De eerdere studies op dit gebied zouden dus op twee manieren kunnen zijn beïnvloed door het weglaten van fondsen die niet meer bestaan. 


\section{Curriculum Vitae}

Rogér Otten was born on March $30^{\text {th }}, 1973$ in Sittard, the Netherlands. He studied Business Economics at the University of Maastricht. During his studies he participated in an exchange program, which enabled him to spend 6 months at the University of Hanover, Germany. In 1997 he received his masters degree. After that he joined the Finance Department at the University of Maastricht to work on his $\mathrm{PhD}$ dissertation on European mutual funds. During the 1998-1999 period he was also employed at ABP Investments, the pension fund for Dutch civil servants. There he was involved in Quantitative Equity Research. In June 200I Rogér Otten was appointed as an Assistant Professor of Finance at the University of Maastricht. His work on mutual funds has been published in various journals like European Financial Management, Managerial Finance, VBA Journaal and ESB. Furthermore he is quite active in executive teaching, among others for the Dutch Financial Analysts Association (VBA) and the Dutch Real Estate Institute (SBV). Finally he is involved as an academic associate at FundPartners, an independent product development company for investment funds. 
This thesis intends to add to the understanding of the European mutual fund industry. As more and more people are using mutual funds, for instance as a means to take care of their pension, this is of eminent importance. While the US industry has been studied for over 40 years, little is known about the structure and performance of the European industry. This thesis provides evidence on both issues. The results presented here should be of interest to both private and institutional investors, regulators and of course academics.

Rogér Otten was born on March $30^{\mathrm{t}}, 1973$ in Sittard, the Netherlands. He studied Business Economics at the University of Maastricht. During his studies he participated in an exchange program, which enabled him to spend 6 months at the University of Hanover, Germany. In 1997 he received his masters degree. After that he joined the Finance Department at the University of Maastricht to work on his Ph.D. dissertation on European mutual funds. During the 1998-1999 period he was also employed at $\mathrm{ABP}$ Investments, the pension fund for Dutch civil servants. There he was involved in Quantitative Equity Research. In June 2001 Rogér Otten was appointed as an Assistant Professor of Finance at the University of Maastricht. His work on mutual funds has been published in various journals like European Financial Management, Managerial Finance, VBA.Journaal and ESB. Furthermore he is quite active in executive teaching, among others for the Dutch Financial Analysts Association (VBA) and the Dutch Real Estate Institute (SBV). Finally he is involved as an academic associate at FundPartners, an independent product development company for investment funds. 